\title{
Collective management of irrigation in eastern Spain. Integration of new technologies and water resources
}

Ph. D. Thesis

November 2015

\section{Mar Violeta Ortega Reig}

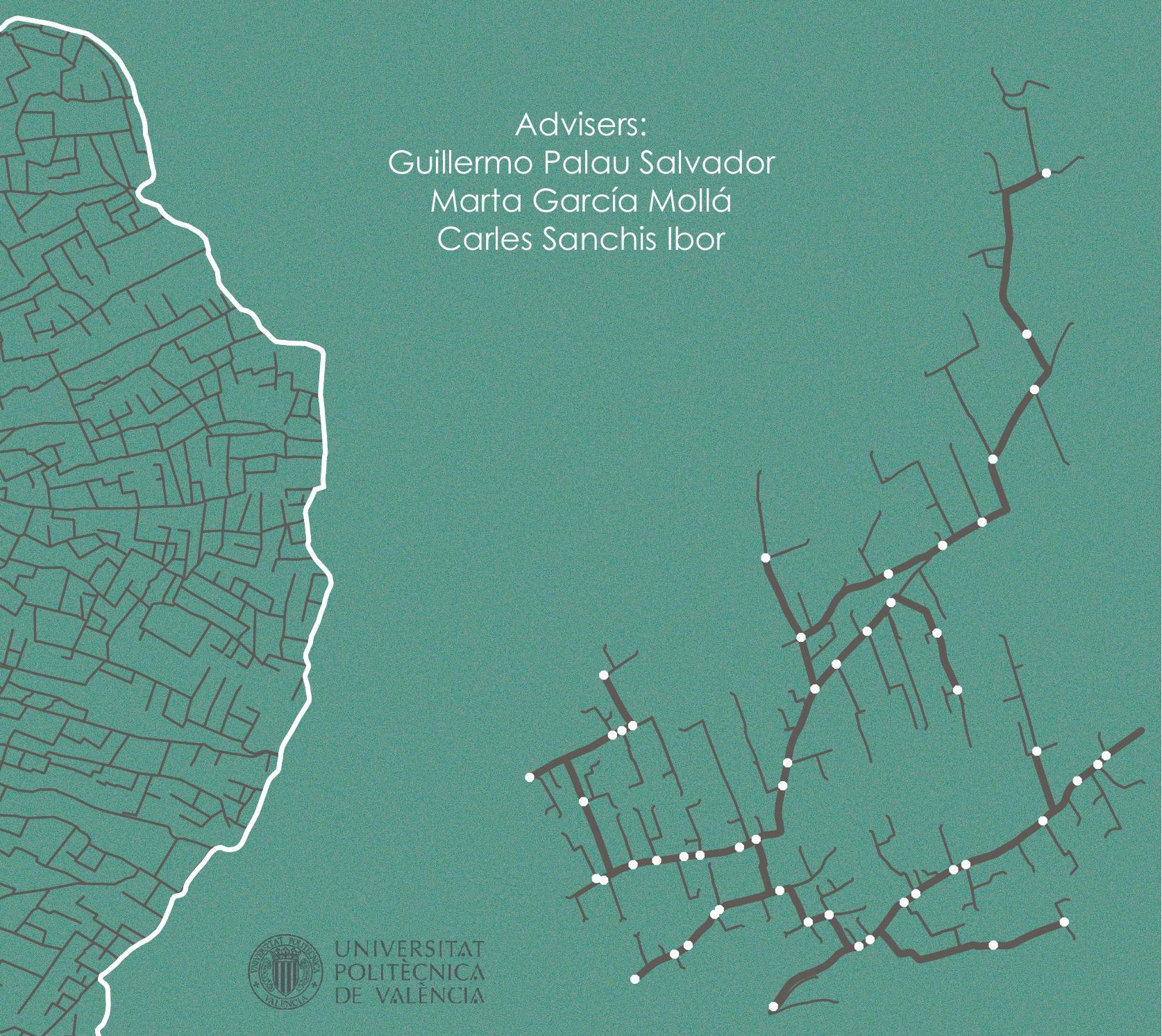


Layout adapted from

Mireia Miralles Lamazares 


\title{
Collective Management of
}

\section{Irrigation in Eastern Spain}

\section{Integration of New Technologies}

\section{and Water Resources}

\author{
Mar Violeta Ortega Reig \\ November 2015 \\ Universitat Politècnica de València (UPV) \\ Ph.D. Program in Water and Environmental Engineering
}

Adviser

Prof. Dr. Guillermo Palau Salvador

Departamento de Ingeniería Rural y

Agroalimentaria

Universitat Politècnica de València
Adviser

Prof. Dr. Marta García Mollá

Centro Valenciano de Estudios sobre el Riego

Universitat Politècnica de València

Adviser

Prof. Dr. Carles Sanchis Ibor

Centro Valenciano de Estudios sobre el Riego

Universitat Politècnica de València 



\section{Collective Management of Irrigation in Eastern Spain Integration of New Technologies and Water Resources}

Mar Violeta Ortega Reig 

M'estime molt, de bon matí, treballar el meu hort les bledes, les lletugues, els raves, les tomaques; regue els breus solcs a poalades lentes, arrenque les brosses nocives.

avui deia el diari que ha arribat l'home a la lluna; m'he girat a mirar-la, vinclat sobre el solc; no he vist res $i$ he continuat.

Vicent Andrés Estellés

Les pedres de l'àmfora. Obra completa 2, (1972, p.252), L'Estel, Valencia (Spain) 



\section{Summary}

The aim of this thesis is to analyze how farmer-managed systems adapt to the changes related to the integration of new water resources and drip irrigation technologies. This work includes two main parts. The first one focuses on traditional gravity irrigation and the emergence of new water resources. The second one looks at irrigation systems that have been transformed to drip irrigation. All the studies included in this dissertation centre the attention in understanding aspects of collective management. For this reason, special consideration is placed on the perceptions of farmers and managers of Water User Associations by means of semi-structured interviews.

Chapters two and three study the operating principles for water management. These principles, when applied by farmers as collective rules, result in interactions that create equity on water rights and transparency. The study area includes the irrigation system of the Huerta of Valencia (Spain). This system, well known internationally, has traditionally used surface water from the Turia River. Though recently, the use of groundwater and treated wastewater have been integrated with surface water. In this context, the analysis evolves around the subject of how the rules, developed for the sharing of surface water, have been adapted for conjunctive use of these new water resources. In addition, attention is also placed on how this process was crucial for the management of the 2005 - 2008 drought period.

Results show that the operating principles, based in the proportionality and uniformity on irrigation frequency between users, underlie a system of distribution that is equitable, transparent and robust. In addition, the use of drought emergency wells and the reuse of treated wastewater have not resulted in any important conflict. These resources are used together with surface water during drought periods, increasing the guarantee of supply. However, treated wastewater use affects the uniformity on irrigation frequency among Water User Associations. Besides, Groundwater User Associations overlap in irrigated surface, farmers and infrastructure with Water User Associations 
using surface water. This situation results in informal conjunctive use, a strategy that seems effective to deal with drought.

Chapter four analyses the conversion to drip irrigation, an important technological transformation. In order to do that, institutional and management changes are examined. The cases studied are the Acequia Real del Júcar, the Júcar-Turia Channel and the General Community of Irrigators of Vall d'Uixó. At Water User Association level a centralization of managment has been observed (in the irrigation network, water resources managment and the merging of preexisting associations). In addition, the reasons for users to convert, the advantages, disadvantages and their satisfaction are also assessed. Besides, the work examines some aspects of how users adapt the use of irrigation and fertigation technology to their needs, diverging in some cases from the initial criteria of design. The presented results provide a wider understanding of the transformation process.

Chapter five discusses and compares the implications of the previous chapters. Some aspects of irrigation management and governance are assessed in a more detailed manner for the case of gravity irrigation Water Users Associations. In addition, the changes related to the introduction of drip irrigation technologies and new water resources are further compared. The two processes present challenges for irrigation organization. Meanwhile the integration of new water sources has been gradual and does not entail major changes for self-organization, drip irrigation promotes a fundamental institutional change. This change may have a disruptive effect on self-organization if this new community-based drip irrigation does not manage to adapt and include braoder aspects of irrigation management beyond purely agronomic factors.

In conclusion, the thesis reflects on current water policy dilemmas, focusing in currently prevailing water policy measures in the Valencia region, but also at world level: drip irrigation implementation, reuse of treated water and conjunctive use of groundwater and surface water. This allows identifying and comparing local aspects that influence the adoption and adaptation of new technologies and the integration of new water sources. Considering these features in irrigation policy would increase the efficacy of traditional solutions. Including these perspectives would also help to adapt new solutions to collective water and irrigation management settings characterized by significant complexity. 


\section{Resumen}

Este proyecto de tesis tiene por objetivo analizar cómo la gestión comunitaria del riego se adapta a los cambios relacionados con la integración de nuevos recursos hídricos y tecnologías de riego localizado. El trabajo se compone de dos partes, una centrada en los regadíos tradicionales por gravedad y la integración de nuevos recursos hídricos, y una segunda parte que estudia los sistemas transformados a riego localizado. Todos los estudios incluidos en la tesis se centran en conocer aspectos de la gestión colectiva. Por este motivo se hace un especial énfasis en la percepción de los regantes y los gestores de las comunidades de regantes, utilizando entrevistas semiestructuradas.

Los capítulos dos y tres estudian los principios de operación para la gestión del agua. Estos principios, cuando son aplicados por los agricultores como reglas de gestión colectiva, resultan en interacciones que crean equidad entre derechos de agua y transparencia. La zona de estudio comprende el sistema de riego de la Huerta de Valencia (España), un sistema de riego conocido a nivel mundial que tradicionalmente ha utilizado los recursos superficiales del río Turia, pero que recientemente ha integrado el uso de aguas subterráneas y aguas residuales tratadas. En este marco se analiza cómo estas normas, desarrolladas sobre la base de la gestión de los recursos superficiales, se han adaptado para el uso conjunto de estos nuevos recursos y cómo este proceso ha sido crucial para la gestión del periodo de sequía ocurrido entre 2005 y 2008.

Los resultados indican que los principios operativos subyacentes, basados en la proporcionalidad y la uniformidad de la frecuencia de riego entre los usuarios, son el fundamento de un sistema de reparto equitativo, transparente y robusto. Además, el uso de pozos de emergencia de sequía o de aguas residuales tratadas no ha sido fuente de conflicto, pues se utilizan durante el periodo de sequía como un recurso adicional junto con el riego de aguas superficiales, aumentando la garantía de abastecimiento. No obstante, el uso de agua depurada afecta a la uniformidad de la frecuencia de riego entre comunidades. Por otro lado las asociaciones de riego con aguas subterráneas se solapan 
con las comunidades de regantes y, aunque son diferentes organizaciones, comparten en gran medida superficie regable, regantes e infraestructura, resultando en un uso conjunto informal, lo que parece una estrategia efectiva de adaptación a la sequía.

En el capítulo cuatro, se analiza la conversión a riego localizado, una transformación tecnológica significativa. Para ello, se examinan los cambios institucionales y de gestión. El ámbito del trabajo es la Acequia Real del Júcar, el Canal-Júcar Turia y la Comunidad General de Regantes de Vall d'Uixó. A escala de comunidad de regantes, se ha observado una transformación hacia una gestión más centralizada (de la red de riego, de los diferentes recursos hídricos y fusión de organizaciones preexistentes). A nivel de los agricultores, se centra la atención en las razones para la conversión, los pros, los contras y la satisfacción de los usuarios. También se examinan aspectos de cómo los usuarios adaptan el uso de la tecnología de riego y fertirrigación a sus necesidades, divergiendo en algunos casos del criterio de diseńo inicial.

En el capítulo cinco se discuten y comparan las implicaciones de los capítulos anteriores. Algunos aspectos de la gestión y gobernanza del riego se analizan de una manera más detallada para el caso de las comunidades de regantes con riego por gravedad. Además, se comparan los cambios relacionados con la introducción de tecnologías de riego por goteo y nuevos recursos hídricos. Los dos procesos presentan desafíos para la organización del riego. Mientras que la integración de nuevos recursos ha sido gradual y no implica grandes cambios para la gestión colectiva del riego, el riego localizado promueve importantes cambios institucionales. Estos cambios pueden tener un efecto disruptivo en la gestión colectiva del riego si esta nueva gestión comunitaria no logra adaptarse e incluir aspectos más amplios de la gestión del riego, más allá de las consideraciones puramente agronómicas.

En conclusión, esta tesis reflexiona sobre los dilemas actuales de la gestión del agua, centrándose en las medidas que actualmente predominan en Valencia, pero también a nivel mundial: la implementación del riego localizado, la reutilización de aguas residuales tratadas y el uso conjunto de los recursos superficiales y subterráneos. Esto permite identificar y comparar aspectos locales que influyen en la adopción y adaptación de nuevas tecnologías y la integración de recursos hídricos. Tenerlos en cuenta en las políticas de regadío puede aumentar la eficacia de las soluciones tradicionales, ayudando a adaptar nuevas soluciones a ámbitos de la gestión colectiva del agua y del riego caracterizados por una elevada complejidad. 


\section{Resum}

El projecte de tesi té per objectiu analitzar com la gestió comunitària del reg s'adapta als canvis relacionats amb la integració de nous recursos hídrics i les tecnologies de reg per degoteig. El treball està compost per dues parts, una de centrada en els regadius tradicionals per gravetat, i la incorporació de nous recursos, i una altra en els regadius transformats a reg per degoteig. Tot els estudis inclosos en aquesta tesi centren l'atenció a conéixer aspectes de la gestió col-lectiva. Per aquest motiu, es posa una especial èmfasi en la percepció dels regants i dels gestors de les comunitats de regants, mitjançant la utilització d'entrevistes semiestructurades.

Els capítols dos i tres estudien els principis d'operació per a la gestió de l'aigua. Aquests principis, quan són aplicats pels llauradors com a regles de gestió col-lectiva, resulten en interaccions que creen equitat entre drets d'aigua i transparència. La zona d'estudi comprén el sistema de reg de l'Horta de València (Espanya), un sistema de reg de renom internacional que tradicionalment ha utilitzat recursos superficials del riu Túria. Però, recentment ha integrat la utilització d'aigües subterrànies i aigües residuals tractades. En aquest marc, s’analitza com les normes, desenvolupades en base a la gestió dels recursos superficials, s'han adaptat a la utilització conjunta dels nous recursos i com aquest procés ha estat crucial per a la gestió de la sequera que va tindre lloc entre 2005 i 2008 .

Els resultats indiquen que els principis operatius subjacents, basats en la proporcionalitat i la uniformitat en la freqüència de reg entre els usuaris, són el fonament d'un sistema de repartiment equitatiu, transparent i robust. A més a més, l'ús de pous de sequera o la reutilització d'aigües residuals tractades no ha estat cap font de conflicte, ja que s'utilitzen durant els períodes de sequera com un recurs addicional juntament amb les aigües superficials, augmentant-ne la garantia d'abastiment. No obstant això, l'ús d'aigües depurades tractades afecta la uniformitat en la freqüència de reg entre comunitats. D'altra banda, les associacions de reg amb aigües subterrànies se solapen 
amb les comunitats de regants $\mathrm{i}$, tot i que són diferents organitzacions, comparteixen en gran mesura superfície regable, regants i infraestructura. Això genera una utilització conjunta informal que sembla una estratègia eficaç d'adaptació a la sequera.

En el capítol quatre s'analitza la conversió a reg per degoteig, una transformació tecnològica significativa. Per aquest motiu, s'examinen els canvis institucionals en l’organització i la gestió derivats de la implementació de reg per degoteig. L’àmbit del treball es la Séquia Reial del Xúquer, el canal Xúquer-Túria i la Comunitat General de Regants de Vall d'Uixó. A escala de comunitat de regants s'ha observat una transformació vers una gestió més centralitzada (de la xarxa de reg, dels diferents recursos hídrics i fusió d'organitzacions preexistents). A més a més, es posa l'atenció en les raons dels llauradors per a prendre aquesta decisió, i s'estudien els pros, els contres i la satisfacció dels usuaris. També s'examinen aspectes de com els usuaris adapten la utilització de la tecnologia del reg i fertirrigació a les necessitats que tenen, cosa que divergeix en alguns casos del criteri de disseny inicial.

En el capítol cinc és discuteixen i comparen les implicacions dels capítols precedents. Alguns aspectes de la gestió i governança del reg s'analitzen d'una manera més detallada per al cas de les comunitats de regants amb reg per gravetat. A més a més, es comparen els canvis relacionats amb la introducció de tecnologia de reg per degoteig i els nous recursos hídrics. Mentre que la introducció de nous recursos és gradual i no implica grans canvis per a la gestió col-lectiva del reg, el reg per degoteig promou canvis institucionals substancials. Els canvis esmentats poden tindre un efecte disruptiu en la gestió col-lectiva del reg si la nova gestió comunitària no aconsegueix adaptar-se iincloure aspectes més amplis de la gestió del reg més enllà de consideracions purament agronòmiques.

En conclusió, la tesi reflexiona sobre els dilemes actuals de la gestió de l'aigua, i posa l'atenció en les mesures que predominen actualment en València, però també a escala mundial: la implementació del reg per degoteig, la reutilització d'aigües depurades tractades i la utilització conjunta de recursos superficials i subterranis. Això permet identificar aspectes que influeixen en l'adaptació i l'adopció de noves tecnologies i en la integració de nous recursos hídrics. Tindre'ls en compte a l'hora de dissenyar polítiques de regadiu augmentaria l'eficàcia de les solucions tradicionals $i$, al mateix temps, ajudaria a adaptar noves solucions a àmbits de la gestió col-lectiva de l'aigua i del reg, caracteritzats per una complexitat elevada. 


\section{Preface}

Any research about irrigation organization aiming at obtaining conclusions that can be generalized at irrigation management level, such as this one, has to be aware of the limitations inherent to a study of a human group with precise unique and unrepeatable geographical and historical coordinates. This complexity in the point of departure makes more difficult, when not impossible, the statement of universal assertions valid for other contexts different that the studied one, or even for the same one at a different time. Even more, the process of research itself is closely connected to the biographical moment of the researcher, especially regarding the interpretation of results. These peculiarities, far from rejecting the possibility of a rigorous research in the field, invite to create methods of study linked to the different types of practices that occur in the different irrigation contexts. At the same time, it offers the possibility to understand research as an open process linked to practice, with the objective of a continuous improvement and adjustment to the different needs that arise. In these sense, the following dissertation starts from this difficulty and the developed analyses are associated to the studied context, opening up the possibility to get integrated later in a wider analytical framework. 



\section{Acknowledgements}

When one enters the irrigation fields of the Huerta a summer day of irrigation, one feels the irrigation slowness hitting the 21 st century... water babbling, a farmer shouting to the neighbour "you have the water". Meanwhile, no fresh air relieves the 35 degrees feeling of a heat wave. Water mirrors people's conversations and crisscrossing lives along the water canals. Farmers calculate the time water will take to reach other plots. Of course, sourrunded by the green leaves of lettuces, chufa, potato, orange trees and most recently kakis and pomegranates. In some places these plots appear close to city buildings, a living testimony of a periurban Huerta, and a species in extinction in Europe. The interest in this irrigation system was the beginning of this project.

This page acknowledges that this thesis was not an individual project, but required the contribution, time and effort of numerous people. I first wish to thanks my supervisors. Thanks to Guillermo, for starting this journey, for years of invaluable help, support, and advice; and for being attentive and warmhearted. To Marta, for her worthwhile contributions, helping me rethinking the scope of this project and kindly nourishing this work. To Carles, for offering stimulating and constructive thinking and suggestions, making this work evolve with his amusing spirit. I also wish to extend my gratitude to the support I received from Professor Llorenç Avellá in the Centro Valenciano de Estudios sobre el Riego. His advice and guidance introduced me to the drip irrigation WUAs. I am also indebted to Professor Paul Trawick, from the Idaho State University, with whom the interest in common management and traditional irrigation started. I wish to tank as well the co-authors of the papers included in this dissertation, the work we share is a part of this thesis.

I wish to thank the farmers I interviewed for devoting their time, and sharing their experience and opinions. I am also grateful to the Water User Associations. Their guards, workers, presidents and secretaries provided a valuable support to make this work possible. I am especially thankful to the Tribunal de las Aguas, the Real Acequia 
de Moncada and the Acequia Real del Júcar for opening the doors of their history and knowledge.

I would like to thank also the Assut Foundation. Some of its interesting projects about our cultural landscapes constituted an engaging work experience, provided additional financial support and allowed me to collaborate with diverse and delightful people. I am pleased to have met in this way Vicent Sales, another water and irrigation lover, for his long hours of discussion and wisdom.

Thanks also to my colleagues, friends and family for being even sometimes interested in irrigation, letting me share the enthusiasm about these interesting waterscapes, sharing ideas, climbing mountains and making my life more beautiful. Among them I would like to thank Claudia, for her friendwhip and catalan revisions, Ester and Nacho, whose energy, curiosity and friendship inspire interesting adventures; and Alex and Montse, for their insights, questions and guidance, and with whom I have shared many gustatory pleasures. I am especially grateful to my father and my mother, for encouraging me and hearing me, always with love.

To Coco, I give special thanks for his stream of sun, serenity and equilibrium in my life. Your encouragement is the keystone of this thesis. 


\section{Contents}

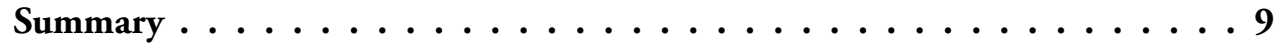

Resumen ........................ 11

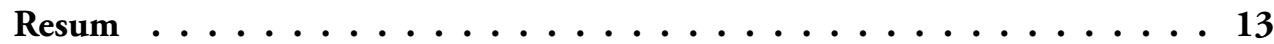

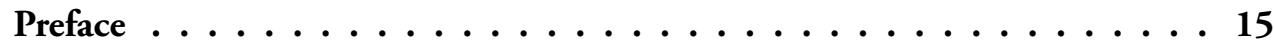

Acknowledgements. . . . . . . . . . . . . . 17

Contents .......................... 19

List of Abbreviations . . . . . . . . . . . . . . . 23

Chapter 1. Introduction . . . . . . . . . . . . . . . 25

1.1 Introduction. . . . . . . . . . . . . . . . . . . 25

1.2 Global background: Irrigation studies . . . . . . . . . . . . . 26

1.3 Self-organization in irrigation studies . . . . . . . . . . . . . . 27

1.4 Farmer participation and management . . . . . . . . . . . . . . . 29

1.5 Socio-technical perspectives and hydro-social territories . . . . . . . . . . 30

1.6 Traditional irrigation systems in Valencia . . . . . . . . . . . . . 32

1.6.1 Traditional gravity-fed irrigation $\ldots \ldots . \ldots 32$

1.6.2 Travelers and the idealization of Valencian irrigation. . . . . . . . . 33

1.7 Water policy in Spain . . . . . . . . . . . . . . . . . 36

1.7.1 Increasing supply . . . . . . . . . . . . . . . . . 36

1.7.2 Reducing demand . . . . . . . . . . . . . . . . . . . 37

1.7.3 Drought management . . . . . . . . . . . . . . . 37

1.7.4 Conjunctive water management . . . . . . . . . . . 38

1.7.5 Implementation of drip irrigation in Spain . . . . . . . . . . . 41

1.7.6 Drip irrigation in the Valencia Region . . . . . . . . . . . . 43

1.7.7 The Water Framework Directive . . . . . . . . . . . . . . . . 45 
1.8 Research objectives and questions . . . . . . . . . . . . 48

1.9 Overview of the thesis . . . . . . . . . . . . . . . . . . . 49

Chapter 2. Encounters with the Moral Economy of Water: Convergent

Evolution in Valencia. . . . . . . . . . . . . . . . . . 55

2.1 Introduction. . . . . . . . . . . . . . . . . . . . . 55

2.2 Infrastructure and social organization in the Huerta, a multi-community system of medium scale . . . . . . . . . . . . . . . 5 57

2.3 Methods used in the fieldwork. . . . . . . . . . . . . . . . . . 62

2.4 Results: the distribution and use of seasonal low water. . . . . . . . . . . 66

2.5 Results: the distribution and use of water during droughts . . . . . . . 75

2.6 Discussion: the hypothesis of convergent evolution . . . . . . . . . . 81

2.7 Conclusion . . . . . . . . . . . . . . . . . . 88

\section{Chapter 3. The Integrated Use of Surface, Ground and Recycled Wastewater in} Adapting to Drought in the Traditional Irrigation System of Valencia . . . 95

3.1 Introduction. . . . . . . . . . . . . . . . . . . . . . .95

3.2 Method . . . . . . . . . . . . . . . . . . .98

$3.3 \mathrm{La}$ Vega de Valencia and its irrigation system . . . . . . . . . . . . . . . . . . . . . .

3.3.1 Historical context and evolution . . . . . . . . . . . . . . . .99

3.3.2 The irrigation operating principles in Valencia using surface water from the Turia River . . . . . . . . . . . . . . . . . . . . 100

3.3.3 The importance of infrastructure to maintain uniformity and proportionality . . . . . . . . . . . . . . . 102

3.3.4 Supplementary resources for WUAs . . . . . . . . . . . . . . . 103

3.3.4.1 Provision of the WUAs' with Drought Emergency Wells . . . . . . 103

3.3.4.2 Recycled Wastewater. . . . . . . . . . . . . . . . . . 103

3.3.4.2.1 Autonomy . . . . . . . . . . . . . . . . . . . 104

3.3.4.2.2 Contiguity, Transparency and Proportionality . . . . . . . . 104

3.3.4.2.3 Uniformity . . . . . . . . . . . . . . . . . . . . . 105

3.3.4.3 Overall perception of the supplementary resources . . . . . . 105

3.4 Groundwater User Associations. Understanding the overlapping of

Water User Associations . . . . . . . . . . . . . . . . . . . 106 
3.4.1 The operating principles in Valencia in Groundwater User Associations 107 3.4.1.1 Autonomy . . . . . . . . . . . . . . . . 108

3.4.1.2 Contiguity . . . . . . . . . . . . . . . 108

3.4.1.3 Proportionality and Uniformity . . . . . . . . . . . . . . 108

3.4.1.4 Transparency. . . . . . . . . . . . . . . 111

3.4.2 Overall perception of GUA management . . . . . . . . . . . . 112

3.5 Adapting to Drought: Integrated Management of Surface, Ground and

Recycled Water. Special measures in severe drought emergencies. . . . . . . 113

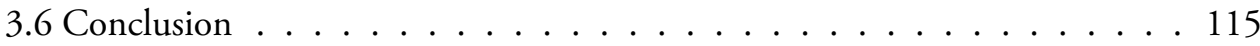

\section{Chapter 4. Institutional and Management Introduction in Collectively}

Managed Irrigation Systems in Valencia . . . . . . . . . . . . 117

4.1 Introduction. . . . . . . . . . . . . . . . . . . 117

4.2 Method . . . . . . . . . . . . . . . . . 120

4.2.1 Case study description . . . . . . . . . . . . . . . . . . 122

4.2.1.1 Acequia Real del Júcar . . . . . . . . . . . . . . . . . 122

4.2.1.2 General Community of Users of the Júcar-Túria Channel . . . . . . 123

4.2.1.3 General Community of Irrigators of Vall d'Uixó. . . . . . . . . . . 124

4.3 Reasons for adopting drip irrigation . . . . . . . . . . . . . . 124

4.3.1 Reasons for adopting drip irrigation, by Water User Associations . . . 124

4.3.2 Reasons for adopting drip irrigation, by farmers . . . . . . . . . . 127

4.3.3 WUAs measures to stimulate drip irrigation uptake among farmers . . 129

4.4 Management changes and adaptation to drip irrigation technologies . . . 130

4.4.1 Changes in the organization: centralization in water management $. ~ . ~ 130$

4.4.2 Changes in irrigation and fertigation management. . . . . . . . . 132

4.4.2.1 Irrigation management . . . . . . . . . . . . . 132

4.4.2.2 Duplicity of irrigation systems . . . . . . . . . . . . . . . 134

4.4.2.3 Fertigation management . . . . . . . . . . . . . . 135

4.4.2.4 Changes in irrigation rules. . . . . . . . . . . . . . 136

4.4.3 Changes in the structure of the staff and training for farmers . . . . 136

4.5 The perceptions of farmers and their satisfaction with drip irrigation . . . 137

4.6 Conclusion . . . . . . . . . . . . . . . . . 138 
Chapter 5. General Discussion of Results. . . . . . . . . . . . . . . . 139

5.1 Trawick's theoretical model and the integration of different water resources . 140

5.2 Changes occurred with drip irrigation technologies . . . . . . . . . . . 144

5.3 Adoption and adaptation of new resources and technologies. . . . . . . . 146

5.3.1 Irrigation management and governance in the traditional Water User

Associations of the Huerta of Valencia and the Acequia Real del Júcar. . . . 147

5.3.2 Comparison of changes related to the adoption of new technologies and water resources $\ldots \ldots \ldots \ldots \ldots \ldots$

5.3.3 Other considerations regarding drip irrigation policy . . . . . . . 151

5.4 Long-term sustainability of traditional systems . . . . . . . . . . 153

Chapter 6. Conclusions . . . . . . . . . . . . . . . . . . . . 157

List of Figures . . . . . . . . . . . . . . . . 163

List of Tables . . . . . . . . . . . . . . . . . . . . 165

References . . . . . . . . . . . . . . . . . 167 


\section{List of Abbreviations}

ARJ

BOE

ESYRCE

EU

GUA

ICID

JDWA

JTC

MAGRAMA

$\mathrm{M€}$

$\mathrm{Mm}^{3}$

NSI

OECD

$\mathrm{UN}$

WFD

WUA

WWAP
Acequia Real de Júcar

Boletín Oficial del Estado - Spanish Official Gazette

Survey about surface and crop yield

European Union

Groundwater User Association

International Commission on Irrigation and Drainage

Júcar District Water Authority

Júcar-Turia Channel

Ministry of Agriculture, Food and Environment

Million Euros

Million Cubic Meter

National Statistics Institute

Organisation for Economic Co-operation and Development

United Nations

Water Framework Directive

Water User Association

World Water Assessment Programme 

"But as engineers we may be apt to err in looking on the perfect of our works and systems as an end instead of only a means of good, and in despising the more primitive arrangements which natives might themselves adopt, and which might possibly be not so inferior to our own."

C.S. Moncrieff (1836-1916), British engineer. ${ }^{1}$

\subsection{Introduction}

In the past decades, water management has been a central issue in international and national political agendas, as a key matter for the sustainability of natural and social systems. As highlighted by the UN World Water Development report of 2015, pressure on freshwater resources poses into question the possibility to fulfil social, economic and environmental needs in a context of growing population. Thus, studies that focus on irrigation management are relevant for water policy as development of irrigation infrastructure and irrigation expansion is proposed to unlock the economic growth potential of water, and to alleviate poverty, vulnerability and increase food security (WWAP, 2015).

There are many examples around the world of farmer-managed irrigation systems that have lasted for centuries. Those systems have maintained collective-action in irrigation over time, showing long-term sustainability, resilience and robustness to drought. As long-lasting systems, they offer the potential to learn about effective water management and institutional arrangements (Cox and Ross, 2011). However, current problems and dilemmas may entail new processes of transformation in these traditional Water User Associations (WUAs). Increasing competition on water resources, urbanisation and city growth, conjunctive use and new irrigation technologies present new challenges for farmer-managed systems. The aim of this thesis is to investigate the 
effects of the incorporation of new water resources and drip irrigation technologies on farmer-managed irrigation systems. This is done by focusing in case studies located in the Valencia Region, both in the Júcar (or Xúquer) and Turia river basins.

\subsection{Global background: Irrigation studies}

Much research on irrigation management has been in dialogue with Karl Wittfogel's (1957) "hydraulic hypothesis". Wittfogel argued that the development of large-scale irrigation schemes led to a need of intensive labour, to a central organization, and to government control, inevitably creating centralized irrigation bureaucracies able to control the political power and the economy. According to Wittfogel, these conditions resulted in a type of "hydraulic society" that was stagnant and resistant to change.

In addition, one of the most influential works on water policy until now has been Garrett Hardin's 'Tragedy of the Commons' (1968). By taking a pasture as a metaphor, Hardin argued that without mutual coercion, among resource users, over-consumption of natural resources will bring the ruin to all. This 'rational choice' argument assumed that, as individuals always act selfishly seeking for their own interests -a controversial assumption-, in order to limit access to the resource the enforcement of private property and state control are the only feasible alternatives. Thus, an important body of literature has been in debate with Hardin's thesis as well, showing that Hardin's case was rather the tragedy of an open-access regime (Feeny et al., 1990). Instead of natural resources over-exploitation, Elinor Ostrom's work (Ostrom, 1992, 1990), based on ethnographic studies and analytical models, saw cooperation between individuals with shared interests in order to establish governance rules to share common resources (Rasmussen and Orlove, 2014).

In this context, new research about farmer-managed irrigation systems and common-pool-resources ${ }^{2}$ management appeared challenging Wittfogel and Hardin's thesis. Both Thomas Glick's (1970) historical analysis on irrigation and society in medieval Valencia and the comparative irrigation study of Arthur Maass and Raymond Anderson (1978) draw attention to operating principles on water management in the Valencian irrigation systems. Other scholars focused on the study of the social

2. Common-pool-resources are charaterized by the difficulty of excluding individuals from its use, which makes possible for them to free-ride. In addition, common-pool-resources are also characterized by their subtractability (or rivalry). Therefore, the use of the resource by one individual reduces the total amount of resource available for the other users (Ostrom, 1990). 
organizational arrangements existing in long-lasting, locally-managed irrigation systems around the world (Boelens and Hoogendam, 2002; Coward, 1979, 1976; Hunt, 1989, 1988; Lam, 1998; Mabry and Cleaveland, 1996; Ostrom, 1992; Trawick, 2008, 2001a).

\subsection{Self-organization in irrigation studies}

The study of collective irrigation management has focused on how groups of individuals develop effective, viable and sustainable institutions and, by means of cooperation, restrain collectively the consumption of natural resources, thereby avoiding the wellknown Hardin's (1968) 'Tragedy of the Commons'. Moreover, collective action theory, based on empirical studies done all over the world, provides wide-ranging evidence on cases where groups of individuals have been able to overcome their potential problems in order to achieve common objectives (Dietz et al., 2003). Despite this, there is still a need to shed more light on the reasons why individuals engage in cooperation in managing scarce resources.

The appearance of relatively new ethnographic studies on farmer-managed irrigation systems has identified a set of basic principles that appear to underlie success in different parts of the world; these studies help to shed light on the theory of effective irrigation institutions (Trawick, 2008, 2001b). Hunt (1989) highlighted the importance that equity has on the distribution of benefits in order to solve the usual problem between tail- and head-enders. Mabry and Cleaveland (1996) maintain that, even though equity is a cultural concept that can be defined in different ways (access to means of production, obligations, benefits distribution, shares of risk, etc.); indigenous agriculture tends to be more equitable than industrial irrigated agriculture. Trawick (2005) argues that equity seems to be defined as proportionality among rights and duties, which in order to be achieved requires a uniform irrigation frequency among users.

The collective-choice literature, based on empirical evidence and laboratory experiments, poses collective-management as a viable alternative to Hardin's limited options of privatization and state control (Dietz et al., 2003; Ostrom, 1990). On the basis that individual motivation and the behaviour of the other users are key issues for cooperating and devising sustainable institutions (Ostrom, 1990; Trawick et al., 2006), extensive literature describes and explains cases where individuals engage in cooperation in order to solve social dilemmas and obtain collective positive outcomes (Ostrom, 1998). Despite the existing theoretical disputes, the conclusion arrived at after studying 
widely common-pool resources is that Hardin's model has serious limitations (Feeny et al., 1990; Marshall, 2005; Stern et al., 2002). Moreover, communal management of a resource can be a more convenient social solution (Lam, 1998, 1996; Mabry and Cleaveland, 1996).

The work of Ostrom, with a strong focus on community management, laid the foundations for the studies on governance of common-pool-resources. It also proved useful to rebate Hardin's tragedy in small-scale and locally governed commons (Araral, 2014). However, Araral (2014) argues there is no clear justification to consider its applicability on large-scale or global commons. Its lack of applicability to largescale systems was indeed noted by Ostrom (1990) when considering face-to-face communication between users (dependent on group size), hetereogenity, difficulty of monitoring, and clearly defined boundaries as relevant characteristics for successful cooperation. In addition, local communities require, in general, the support of levels of governance higher than the local level (such as the State) (Mansbridge, 2014).

Although community management of water resources is frequently seen as an alternative to state management or privatization of the resource, the capacity of collective action to achieve sustainable groundwater management is open to question. The difficulty to monitor water use and to set clear boundaries on the resource and the user group, as well as the large extension of the aquifers, are critical factors (Moench, 2007; Ross and Martinez-Santos, 2009). Therefore, groundwater resources result in many respects in an open-access situation (Giordano and Villholth, 2007).

Faysse and Petit (2012) compare the research perspectives adopted by the different main schools that have focused on groundwater governance: the Bloomingtol school, represented by Elinor Ostrom's work in user's participation; the political economy school initiated by Tushaar Shah and the latter political ecology school. The authors highlight that the work developed by the different schools was strongly influenced by the circumstances of their initial works (type of aquifers, type of use and administrative context).

For instance, the work of Ostrom (in California), was developed in a context where users were willing to participate in designing management rules, with strong of support of the public administration. In contrast, the work of Shah (2009) in South Asia, shows that many constraints for the implementation of a groundwater governance regime exist. For instance, the high numbers of users, population pressure and the 
limited means of public authorities make difficult and costly to restrict groundwater access or to implement farmer's entitlements. In this context, the work of Shah (2012; 2008) devotes more attention to strategies for enhancing demand-side management measures (Faysse and Petit, 2012). In addition, Shah's evidence (2014, 2012) does not support the likelihood of small farmers agreeing on reducing groundwater use in order to achieve a sustainable use in alluvial aquifers. However, Shah (2012) also shows that in hard rock aquifers, where the effects of interdependency of groundwater pumping are earlier observed, there are a some cases were communities have engaged in cooperation strategies for groundwater recharge.

\subsection{Farmer participation and management}

Examples of self-governance, as the cases mentioned in the previous section, are relevant for the irrigation literature because they prove the ability of irrigators to govern themselves. In a water policy context that has long promoted farmer's participation and irrigation management transfer (turnover), these cases are central in the discussion, and challenge the hypothesis of Wittfogel (1957) which argues that large scale irrigation systems require strong central authority for irrigation organization and development (Palerm-Viqueira, 2009).

In irrigation systems promoted by development policies or previously managed by state agencies, the main discourse and justification for promoting farmer's participation and organization is to improve performance and efficiency, as farmer's participation may contribute to making irrigation management more effective while supporting equitable sharing of water. The assumption is that problems are better addressed by users experiencing them and that farmer's engagement in maintenance can lead to better and more sustainable outputs (Molle, 2005). Since the 1990s financial crisis, international agencies and governments became more interested on farmer's participation, as a key issue to address maintenance problems and reduce operation and management costs (Meinzen-Dick, 2007; Suhardiman et al., 2014; Thiel et al., 2015). In irrigation management, many efforts have been devoted to create Water User Associations (WUAs), based in an analogy to small traditional systems, due to the inefficient use of water and lack of maintenance by tail-end farmers (Coward, 1979, 1976; Hunt, 1989).

The results have been diverse, mainly because of lack of farmer empowerment 
and incentives, lack of redistribution of roles and tasks and poor accountancy of leaders to farmers (Hunt, 1989; Meinzen-Dick, 2007; Molle, 2005; Mukhtarov et al., 2015; Uphoff and Wijayaratna, 2000). In many cases the reach of policy implementation has been to transfer to farmers the task of infrastructure maintenance, and tax collection, reducing operating costs of the public agency but without transferring control over water or conflict solving (Hunt, 1989). The initiative to develop legal and policy bases for participation has been framed by persuasive insistence from international agencies and development banks, generally designed with participation of foreign consultants, borrowing general recommendations and sometimes overlooking local specificities (Molle, 2005; Mukhtarov et al., 2015; Thiel et al., 2015). These processes tend to leave state control intact and result in weak enforcement, sometimes paying lip service to mainstream thinking (Molle, 2005).

Palerm-Viqueira (2009) claims theoretical differentiation between governance and management gives relevant analytical insights for analysing farmer-managed irrigation systems. For instance, this differentiation helped elucidate changes occurred in the Mexican irrigation management transfer, and it may also be useful to expand the analysis of modernization of irrigation systems. In the case of irrigation districts previously managed by Mexico State, the responsibility of the operation of the system has been transferred to farmers; the difference is that the technical staff is now hired by the WUA. In this case, the previous bureaucratic model has been transferred to the WUAs (Palerm-Viqueira, 2009).

\subsection{Socio-technical perspectives and hydro-social territories}

In the 1980s, the interest on socio-technical studies of irrigation aroused from largescale irrigation development projects resulting in less productivity than expected. In turn, they focused on social organization as a response to a dominant approach more centred on infrastructural management (Mollinga, 2014). Many of these studies focused on farmer-managed irrigation, paying attention to institutional arrangements, water management and the physical setting (Coward, 1990, 1979; Hunt, 1989; Ostrom, 1992; Trawick, 2002; Wade, 1987). Regarding water and irrigation management, Uphoff et al. (1985), Uphoff (1986) and Coward (1985) conceptualized irrigation as a socio-technical process, recognizing the importance of looking at irrigation activities both considering physical and social processes as intimately associated. 
However when looking more specifically at socio-technical perspectives, the social construction of technology (SCOT) school, the actor-network theory (ANT) and Large-Scale technological systems (LTS) approaches have drawn attention to how actors define the boundaries between the social and technical issues, 'opening the black box' by acknowledging the social and technological aspects of technology and their interactions (Bijker et al., 2012; Luján and Moreno, 1996). Moreover, technologies and social processes influence and re-shape each other. How a technology works depends on the users, and integrates their knowledge, organizational processes, values and cultural perspectives, as well as technical aspects of it. Hence, technology and physical infrastructure have not a fixed effect or impact but depend on the social and institutional arrangements around them (Garb and Friedlander, 2014). In this line, the proposition of 'technography' as a methodological approach aims at capturing this interdisciplinary perspectives (Jansen and Vellema, 2011).

In regard of irrigation management, Benouniche et al. (2014b) have studied how farmers have adapted and elaborated own technical standards and how it made drip irrigation a successful innovation through a process defined as 'bricolage'. Van der Kooij et al. (2015), show how social organization has evolved together with infrastructural irrigation changes in Seguia Khrichfa (Morocco) and, more recently, with drip irrigation. In this case, the introduction of new types of technologies set the scene for changes on decision making power and redefinition of stakeholders' rights. Mollinga (2014) describes how different policies of colonial origin in India have shaped different types of irrigation infrastructure, and in turn, social interaction and water operation principles in surface irrigation.

Boelens and Vos (2012) claim that governments and donors in many parts of the world are concerned with increasing irrigation efficiency. However, the authors argue that common concepts used by policy-makers (irrigation efficiency, water productivity or crop water requirements) are not empty of social relations and do not exist as impartial concepts. Where (and to whom) is the saved water going? These studies highlight the need to understand institutions and technology as a socio-technical network that is continuously re-ordering.

In an effort to capture the complexity of water management and governance an emerging hydro-social perspective recognizes the combined nature of water landscapes 
and the hydrological cycle as hydro-social 'hybrids', insisting in the inseparability of physical and social processes. In contrast with depoliticised approaches, water concerns are not addressed as a mere administrative question, but deeply embedded in power relations (Boelens, 2014; Swyngedouw, 2009, 1999). For instance, Swynguedouw (2013) questions the silence on power relations and 'critical' water literature, and the decidedly depoliticised language of the UN World Water Development Report. Therefore, this approach acknowledges the lack of neutrality of processes of socio-environmental and social-technical change, which undermine the stability of some groups and enhance the sustainability of others (Molle, 2008; Swyngedouw, 2009). In addition, these perspectives also call for an analysis transcending the limits and boundaries of academic disciplines (Swyngedouw, 2009, 1999).

\subsection{Traditional irrigation systems in Valencia}

\subsubsection{Traditional gravity-fed irrigation}

In Valencia there is a long-standing tradition on farmer-managed irrigation, where groups of farmers sharing collectively a water allowance have invested in developing and maintaining an intensive channel landscape, sometimes dating back to Arab times. This traditional infrastructure management has been based in rules (or institutions) for hydraulic management, irrigation practice, adapting to drought, and most importantly for conflict resolution.

For instance, the irrigation system of the Huerta of Valencia (or l'Horta) is one of the most well-known farmer-managed irrigation systems around the world, where effective cooperation on irrigation has overcame many difficulties of collective resources management, achieving a low level of free-riding. Although there are water officials hired by the WUAs, conducting operation tasks at main channel level, farmers conduct many tasks related to irrigation management and water distribution. Operating irrigation requires and entails knowledge intensivity, the existing rules have been reformulated and redefined to adapt to the social and ecological environment though history (Glick, 2010). In this sense, as highlighted in the classical study of Maass and Anderson (1978), water distribution in the Huerta of Valencia irrigation system is based on principles of equity, social justice, economic efficiency and local control. In many Mediterranean irrigation systems main management responsibilities were placed in downstream users. This arrangement acted as mechanism of guarantee against water theft by upstream 
users (Lana-Berasain, 1999).

Since the 1980s there has been a profound transformation in the irrigated areas in the Valencia Region (Ramón-Morte, 1995). Gravity irrigation with channels has been replaced by pipelines, laterals and drippers for under pressure water distribution. Glick (2010) noted, the disappearing of traditional irrigation implies the disappearing of ties which unite irrigation communities (or WUAs). The irrigation turn, where a famer goes to look for the water, waits for it and conducts it up to the field is now substituted by electrovalves automatically actioned from the office of the WUA to allocate water to farmers. It is a striking and unprecedented change in Valencian agriculture.

In a context of strong competition over water resources, the dominant discourse assigns to traditional irrigation farmers the adjective of obstinate water wasters (Glick, 2010; Sanchis-Ibor et al., 2016). For instance, Gómez-Limón and Martín-Ortega (2013, p. 303), refer to the Spanish National Irrigation Plan as one "which includes plans for (...) the modernization of obsolete irrigated systems.” Even though surface irrigation is in clear recession in Valencia, the word obsolete gives the sense of something being no longer useful because something new exists. However as Ftaïta (2010) analyses for the case of community-based models in Moroccan oasis, are traditional systems unsuitable for modernity? Many of these traditional systems are well known for its proved efficacy and limited costs. In this case understanding irrigation management in a wide sense, where the system combines robustness to drought, social organization and environmental sustainability. However, social pressure and policy-making pushes substitution of the traditional irrigation systems for the sake of an increased irrigation and economic efficiency.

\subsubsection{Travelers and the idealization of Valencian irrigation}

The study of irrigation organization and management was a subject of interest for British and French engineers in the 19th century. Several travellers and engineers visited Spanish irrigation systems with the intention of applying this knowledge in colonial India and Algeria (Garrido, 2014). Several foreign observers showed special interest for local control of irrigation systems. The first one was Jaubert de Passa (1823) in his travel to study irrigation, water institutions and intensive agriculture. He described the Huerta of Valencia irrigation system and the Acequia Real del Júcar (ARJ). Maurice Aymard (1864), an engineer from the French colony of Alger, also paid attention to water 
administration. Afterwards, Clements R. Markham in 1867 and Colin Scott Moncrieff, the following year, visited the ARJ and the Huerta of Valencia (Glick, 1991). Similarly, in 1886 the Italian engineers Giuseppe Zoppi and Giacomo Torricelli visited as well the region (Calatayud, 2004). Later, the geographer Jean Brunhes (1902) conducted a comparative analysis of water distribution, water sharing and regulation of scarce resources in Spain (including Valencia) and the North of Africa.

On the one hand, these travellers were not captivated by the technical aspects of irrigation (canal design, low derivation dams, absence of water measurements, payment per entitled land, etc.). On the other hand, they found interesting aspects of irrigation management and social organization (Calatayud, 2004; Glick, 1991). The observations of this travellers were limited by the short time spent and the language barriers, being influenced by their preconceptions and previous reports. These important aspects, together with a disdain for primitive technology, prevented them from getting the deeper knowledge needed to understand the logic underlying irrigation management. In this sense, those travellers did not realized the intricate links between the 'primitive' technology used and the effectiveness of the existing institutions. In contrast, Jean Brunhes (1902) realized the importance of limiting the expansion of irrigated lands, and the trade-off between having a lower area with water rights and increasing the guarantee of water supply (Garrido, 2014).

Nevertheless, these observations were not always faithful, especially regarding the exaggerated admiration of the immutability of institutions since Moorish times and the democratic governance of the system. Their reports contributed to the idealization of farmer's self-governance in a time when the decision power was, at least formally, in the hands of landowners. In addition, the intervention of the Crown and external institutions on water management was limited but it existed (Garrido, 2014; Peris-Albentosa, 2014a). Besides, the importance of town councils in local irrigation management was significant during the 19th century in most Spanish canals (Garrido, 2014). In the case of the Real Acequia de Moncada, farmer's representatives in the Governing Board were the mayors or other members of the town councils, who represented local agricultural elites (Sales-Martínez et al., 2014). Therefore, the excessive idealization of a high degree of autonomy of irrigation institutions needs to be carefully considered (Peris-Albentosa, 2014b).

In this sense, the reports of those travellers influenced the following travellers 
and contributed to create a myth or idealization about Spanish irrigation institutions (Calatayud, 2004; Garrido, 2014). This foreign attention was going to have, in turn, an influence shaping afterwards the Spanish institutions (Calatayud, 2004). The Spanish edition of Jaubert de Passa's book in 1844, highlighting the virtues of the traditional irrigation organization, had the aim of influencing the ongoing process of redefinition of water rights. The dissemination of an image of consensus among farmers, minimum conflict, autonomy, democracy and justice was favoured by an agrarian oligarchy trying to maintaining the status quo in moments of transformations of the legislative framework and institutions (Calatayud, 2004; Peris-Albentosa, 1997). The bourgeois revolution in Spain implied a trend towards racionalization and centralization, resulting in the creation of different types of user's organizations. In addition, it also promoted the homogenization of water rights, although the implementation of the principle where 'no one should irrigate twice until everyone has irrigated once' found more obstacles and resistances. This principle had to be implemented by means of looking for increasing available flows, in order to be compatible with maintaining previous water rights (LanaBerasain, 1999).

As Samuel Garrido (2014) argues, in contrast with other travellers Maurice Aymard noted the ongoing institutional changes occurring in Spain at that time. In addition, the farmer management described in 19th century reports became afterwards implemented, although it is a very recent use. Similarly, the diffusion to other Spanish regions of the 'Valencian model', consisting of an irrigation community (or a WUA), is also relatively recent (Garrido, 2014; Lana-Berasain, 1999).

Garrido (2014) claims these reports influenced directly or indirectly the works of Thomas Glick (1970) and of Arthur Maass and Raymond Anderson (1978) which, in turn, influenced Elinor Ostrom's (1990) work on the conditions under which farmers' groups manage water successfully. One of the cases analysed by Ostrom (1990, 69-82; 1992) was indeed the Huerta of Valencia, based on those previous studies. Garrido $(2011,2012)$ has critically reviewed and discussed, based on historical data, the evidence used in the work of Ostrom (1990) for the study of irrigation institutions in eastern Spain, showing imprecisions regarding the expansion of the irrigation systems and farmer's participation. Tomás Peris-Albentosa (2014a) has also claimed Ostrom's vision of the system was rather idealized, minimizing the importance and extent of hydraulic conflicts. 
Tomás Peris-Albentosa (2014a) notes the importance of conflict has been underestimated in the historical analysis. According to Lana-Berasain (1999), managing irrigation insfrastructure in Navarre required complex social interactions that were shaped through a long historical process, cumulative and without absence of conflict. In episodes of extreme drought in Valencia the use of military forces was in some cases considered necessary to contain water theft or to apply water alternation (MangueAlférez, 2011; Peris-Albentosa, 2014a). However, according to Peris-Albentosa (2014a) the existence of conflict did not lead to Hardin's tragedy but was a driver to develop institutional solutions and agreements that were effective and flexible enough to adapt to the unpredictability of available resources. In this sense, conflict management processes (and not the absence of conflict) were significant to develop a set of Valencian irrigation institutions that have been considered until now a referent for the management of common resources.

\subsection{Water policy in Spain}

\subsubsection{Increasing supply}

The 20th century water policy in Spain was focused on the development of public hydraulic infrastructure (reservoirs, water transfers, irrigation channels) in order to increase water availability and develop new irrigated areas (Swyngedouw, 2007). This policy, based on the principle that water is not scarce and considering water as a production factor, stimulated the use of water to promote development and economic growth. In this sense, there was a very modest interest on the control of water abstractions (CarlesGenovés et al., 2008; López-Gunn, 2009). For instance, until the 1985 Water Law there was a lack of control on groundwater use, characteristic of an open-access situation. This context also encouraged a strong development of new groundwater irrigation areas during the 20th century.

Even though this policy had significant positive effects such as increasing the guarantee of urban supply, food security and rural development (Carles-Genovés et al., 2008), it has also resulted in the unsustainable increase of irrigated land and water rights. This situation has posed strong pressure over water resources due to water demand (and rights) being close to available renewable resources (Andreu et al., 2010). As a result, there is strong pressure in coastal Mediterranean basins, sometimes in the detriment of water dependent ecosystems. These reasons, together with an increasing difficulty on 
expanding water resources availability, technically and economically, has resulted in a shift in the water management model towards demand-side management (Sanchis-Ibor et al., 2016).

\subsubsection{Reducing demand}

In the past twenty years, as a result of the existing conflicts and environmental problems, there has been a growing concern on the need to reduce water demand. In this context, policies targeting the improvement of technical and economic efficiency have been of growing importance. According to Carles-Genovés and García-Mollá (2003) the shift on the water policy paradigm starts with the Water Law of 1985 and according to Del Moral (2009) with the failed Water Plan of 1993. In any case, the culmination of this process is reflected in the Spanish green document on water "libro blanco del agua" (MAGRAMA, 1998).

Some of the demand-side management measures include the improvement of water use, implementation of control mechanisms and promotion of irrigation infrastructural improvements in order to achieve a reduced water demand. In Spain, demand-side management policies have been mainly devoted to drip irrigation implementation, which has also resulted in an increase in the control of water use (López-Gunn et al., 2012a). This technological shift is linked to a similar tendency in many irrigation systems around the world since the 1990s. However, the importance of drip and sprinkler irrigation in Spain is significant as only China and India have larger irrigated areas using these technologies (ICID, 2012).

\subsubsection{Drought management}

Another essential issue influencing recent water management policy has been drought management. One of the worse draughts in the last decades occurred between 1990 and 1995, where mean reduction of rainfall was around 12\% (MAGRAMA, 2009a). The social impact of this drought has determined the position of public and private water management stakeholders in Spain (García-Mollá et al., 2013; Sanchis-Ibor et al., 2016). In addition, in relation to drought risk planning, 23 laws and regulations (only at national level) were published between 2005 and 2008 (MAGRAMA, 2009b), coinciding with the drought period occurred during the hydrological years 2004/2005 and $2007 / 2008$. 
Conjunctive use of surface and groundwater has been of great importance for drought management in Mediterranean river basins. In the Júcar District (which includes both the Júcar and Turia River Basin), during the 2005-2008 drought, approximately $35 \mathrm{Mm}^{3}$ over ordinary groundwater extractions were used, coming from individual or collective wells. Additionally, around $40 \mathrm{Mm}^{3}$ from drought emergency wells were also used (this type of wells can only be used during droughts and its use requires authorisation from the river district water authority, see section 3.3.4.1. for more details). Furthermore, during this drought period other non-conventional resources were used: 're-pumping' of drainage water from rice cropping (up to approximately $90 \mathrm{Mm}^{3}$ ) and irrigation with treated wastewater from Valencia metropolitan area, which accounted nearly for $94 \mathrm{Mm}^{3}$. Regarding treated wastewater reuse (presented in more detail in Chapter 3), the WUAs comprising Valencia's Water Tribunal ceded a part of their entitled surface water resources from the Turia River for Valencia's drinking water supply (Andreu et al., 2010).

According to Andreu et al. (2010) ${ }^{3}$, the conducted management allowed to overcome the most intense drought since weather records began in the Júcar District. This was possible due to conjunctive use not only of surface and groundwater resources but also treated wastewater and re-pumped water. It also included conjunctive management of both Júcar and Turia River Basins, an issue that had also been subject ofprevious studies (JDWA, 2003), and the use of decision-making modelling software and a strong follow up and control.

\subsubsection{Conjunctive water management}

The European Water Framework Directive requires solutions to achieve good status of water bodies and sustainable management. In Spanish water scarce basins (where the relation between demand and renewable resources is close to one, and sometimes higher) water policy needs to consider, in addition to demand management, all available resources at basin level in an integrated way. Hence including non-conventional resources (treated wastewater and desalinated water), and taking the advantages of the characteristics of different resources (Andreu et al., 2010).

The uncoordinated use of surface and groundwater has been common until

3. Joaquín Andreu was the Technical Director of the Júcar District Water Authority in charge of water management and planning during the 2005-2008 drought period. 
recently. This lack of coordination can have negative effects. For instance, the intensive use of surface water can result in the increase of groundwater levels, decrease of infiltration in rivers feeding aquifers and the construction of large reservoirs to store water. On the other hand, groundwater use may result in the decrease of piezometric levels, with associated subsidence problems, decrease of aquifer flows into rivers (in some cases reversing river-aquifer relation), impact on groundwater dependent ecosystems and saltwater intrusion (Andreu et al., 2010; Rivera et al., 2005; Sahuquillo, 1989). As both practices are interrelated, system and basin management are key issues for conjunctive management.

It should be pointed out that groundwater is different to surface water in the sense that in many basins aquifers are able to store important volumes of water. Hence, it is possible to use the resource as needed and not only when available (Blomquist et al., 1994). Most potential applications of conjunctive use are related to taking advantage of storage or 'buffer' capacity of groundwater and interconnections, or different flowing dynamics, of surface and groundwater (Andreu et al., 2010; Rivera et al., 2005).

Conjunctive management of surface and groundwater has been defined in different ways. Joaquin Andreu et al. (2010, p. 6) define it as "the use in a conscious and coordinated way of both water resources with the objective of obtaining improvements over the disconnected and not coordinated use". Shah et al. (2006) make a difference between conjunctive use and management, meanwhile "conjunctive water use refers to simultaneous use of surface water and groundwater to meet crop demand. [...] Conjunctive management occurs when system administrators control ground and surface water simultaneously". The latter being less common as it requires institutions and coordination. Blomquist et al. (2001) describe it as when surface and groundwater supplies and storage facilities are operated as "components of a single system". Foster et al. (2010) claim there is no rigorous definition of conjunctive use although they adopt a pragmatic definition considering "only situations where both types of source are developed (or co-exist or can be developed) to supply a given urban area or irrigation canal-command - although not necessarily using both sources continuously over time nor providing each individual water user from both sources”.

These definitions highlight the lack of consensus on defining conjunctive use. However, they seem to strengthen the importance of intended coordination of surface and groundwater management. However, some authors also acknowledge a more 
spontaneous conjunctive use by farmers (Andreu et al., 2010; Foster et al., 2010). This spontaneous use can lead to effective water management strategies but also to aquifer depletion. On the one hand, pumping strategies can increase water replenishment, generating a collective good. Then, users benefit from reduced pumping costs and avoiding saltwater intrusion. On the other hand, it can have opposed consequences.

Conjunctive management of surface and groundwater can be useful for several water management purposes. The potential benefits are reduced exposure to drought, improved guarantee of supply, increased water availability, sustained environmental needs, reduced problems related to drainage, subsidence, overexploitation, saltwater intrusion and reduced water related costs (Andreu et al., 2010; Blomquist et al., 2001; Sahuquillo, 1989; Sahuquillo et al., 2005). In addition, conjunctive management may enhance yield of past irrigation investments, increase sustainability of groundwater irrigation and allow for the use of poor-quality water increasing agricultural production (Shah et al., 2006).

There are different methods of conjunctive management. These methods include direct aquifer recharge consisting in the introduction of surface water, precipitation, run-off water or treated wastewater into aquifers (naturally or artificially by means of pumping, infiltration basins, etc.) for storage or quality improvement. In addition, there is also "in lieu" recharge (or alternate conjunctive use), taking advantage of aquifer storage. In this case, surface water is used in periods of abundance (wet season) and groundwater is more importantly used in periods of surface water scarcity (dry season). In this way water that otherwise would have been extracted is accumulated for when surface water is scarce. Besides, another type of conjunctive management consists on the extraction of groundwater in zones far from the river when availability of surface water is low. This procedure differs in time the effect on river flow to moments of higher surface water availability (Andreu et al., 2010; Blomquist et al., 2001; Rivera et al., 2005; Sahuquillo, 2006).

Despite the potential advantages of conjunctive use have been widely recognized by water management specialists, integrated management of different sources is limited in many cases by institutional arrangements. Even though conjunctive management depends on physical conditions, reasons for conjunctive management are importantly linked to the institutional setting (water law, water rights, economic incentives and constraints of projects). In addition, often several organizations (public and private) 
are involved in conjunctive management. Thus, institutions and governance are key factors determining when and where conjunctive management techniques will take place (Blomquist et al., 2004, 2001).

\subsubsection{Implementation of drip irrigation in Spain}

The Spanish National Irrigation Plan ${ }^{4}$ was passed in 2002 as a response to the existing challenges in irrigation-based agriculture (Figure 1.1). This plan included actions addressed to different types of irrigation systems: irrigated areas with ongoing works in infrastructural improvements and a very limited development of new infrastructures for irrigated areas of social interest. However, the most important program was the Action Plan for the Consolidation and Improvement of Existing Traditional Irrigation Systems, aimed at modernizing irrigation systems and reinforcing its competitiveness (Barbero, 2006; BOE, 2002). In addition, it included complementary actions supporting those programs. These actions consisted on the follow up and monitoring of economic, structural and environmental effects of the works; fostering of technical studies about efficiency, standardization, and homologation; and the development of training actions to technicians and farmers about new technologies and irrigation practices compatible with the environment.

However, the 2005-2008 drought compelled the government to review and reorient the irrigation plan in order to implement ways of reducing water use in agriculture and gain efficiency (OECD, 2007). In 2006, triggered by an ongoing drought period, a Shock Plan for Irrigation Modernization was passed including new actions and financing to achieve additional water savings (BOE, 2006; López-Gunn et al., 2012a). The Spanish National Irrigation Plan timeframe was 2008. However as the funding was finished before than planned actions and works, the royal decree known as the Closing Plan (BOE, 2008), was passed, providing the additional funding needed.

Even though the available information only allows for a rough estimates of the surface benefited, the real investment and the reduction on water use obtained; since 2000 there has been approximately a public investment of 2,900 M€ in nearly $1,470,000$ hectares in order to save $1,813 \mathrm{Mm}^{3}$ of water a year (WWF/Adena, 2015).

4. In Spanish, plan nacional de regadíos. 


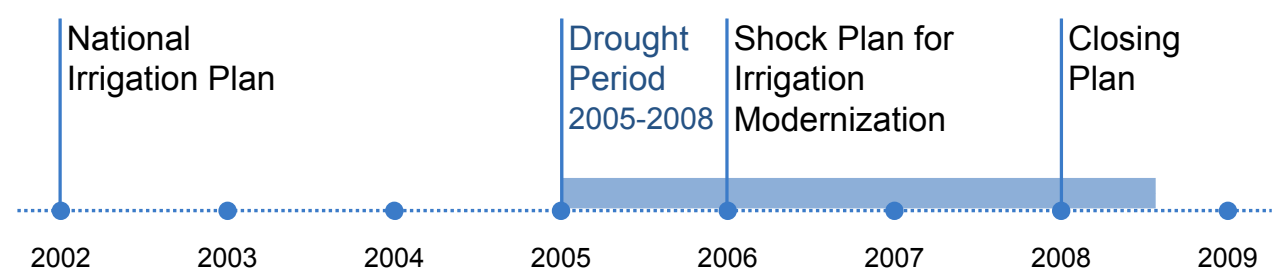

Figure 1.1. Drip irrigation policies in Spain between 2002 and 2009.

Even though the main motivation of 'modernization' plans was to save water, the policies included wider objectives pursuing the improvement of farmer's quality of life. For instance, improving agricultural productivity and competitiveness in order to improve the socio-economic level and rural living conditions of farmers, and also reducing the processes of population loss and aging of farmers in rural areas. In addition, the introduction of technologies had also the objective of reducing water pollution and the incorporation of environmental aspects into irrigation management (BOE, 2006, 2002). The Shock Plan included as new objectives the integration of non-conventional resources (treated wastewater and desalinated water) and to integrate farmers in the society of information by means of implementing "modern communication technologies to achieve a higher global efficiency of irrigation” contributing to developing and consolidating the agro-industrial sector (BOE, 2006). In addition, two royal decrees including the modernization of irrigation infrastructure were passed with the specific purpose of dealing with drought (BOE, 2009, 2005).

Some authors (Allan, 1999; Lecina et al., 2010a; Playán and Mateos, 2006) have criticized that the alternative of improving technical efficiency in order to save water has been the option preferred by decision makers. According to those authors, what makes it most attractive is that improving technical efficiency is an uncompromising option that causes no clear "losers" but benefits farmers, manufacturers and there is few political stress associated to it. Meanwhile, improving water management or the more critical issue of revising water allocation are not targeted, in many cases, due to its important political price (Allan, 1999).

However, some weaknesses of the Spanish National Irrigation Plan implementation have also been mentioned: the meagre initial evaluation of socioeconomic aspects, a careful monitoring plan to track effectiveness during implementation 
and the apparent lack of a beforehand established criteria to decide how to allocate funds in relation to the established objectives (López-Gunn et al., 2012a; Sanchis-Ibor et al., 2016). In addition, the plan translated directly technical efficiency improvements into water savings at basin level (López-Gunn et al., 2012a; WWF/Adena, 2015), an assumption widely criticized to overlook many aspects related to water management scale (Perry, 2008, 2007; Perry et al., 2009; Playán and Mateos, 2006).

Furthermore, several authors noted the lack of transparency, limited data availability and difficulties to access information regarding drip irrigation implementation (López-Gunn et al., 2012b; OECD, 2010; Sanchis-Ibor et al., 2016; WWF/Adena, 2015). In addition, we are not aware of any publicly shared information about the complementary actions supporting those programs.

\subsubsection{Drip irrigation in the Valencia Region}

The region of Valencia is located in the Júcar District, where $80 \%$ of the total water demand corresponds to agriculture (JDWA, 2014a). In the Júcar District, even though river regulation capacity provides an inter-annual storage capacity, water management is determined by scarcity, due to demand being close to available resources, and uncertainty of water availability due to the irregularity of rainfall. In this setting, management of water for irrigation has low guarantee of supply and is embedded in a context of growing pressure, due to environmental problems on wetlands, aquifer overexploitation and population growth. In Valencia, similarly to other water scarce regions, water is inevitably intertwined with the development and culture of the area, and these previously mentioned factors collide recurrently in political and public policy arenas.

Currently, in the region of Valencia there are 285,701 ha of irrigated land, 91,585 ha of gravity irrigation and 192,267 ha of drip irrigation. Between 2004 and 2014 drip irrigation has increased by 83,400 ha $(77 \%)$ whereas gravity irrigation has decreased by 54,642 ha (37\%) (MAGRAMA, 2015a). Both types of irrigation systems coexist in the 21 st century Valencia and even though its important differences, a common feature is to be collectively managed by WUAs in most cases.

The transformation to drip irrigation in the Valencia Region has been fast and important. In 1992 there were approximately 50,255 ha using drip irrigation (RamónMorte, 1995), this surface increased up to 148,086 ha in 2005 and corresponded to 192.267 in 2014 (MAGRAMA, 2015a) (Figure 1.2). The recent technological 
transformation to drip irrigation can be divided in two phases: a first one, previous to 1994, where the implementation of drip irrigation corresponds to farmer's initiative. It comprises both new irrigated areas and areas characterized by important scarcity (Ramón-Morte, 1995). In addition, there was a second phase with a prominent role of public investment programmes for the transformation of approximately 130,000 ha, where WUAs who decided to shift to drip irrigation applied for public investment programmes from the State and Regional Governments ${ }^{5}$ (Sanchis-Ibor et al., 2016).

\section{Evolution of irrigated surface in the Region of Valencia}

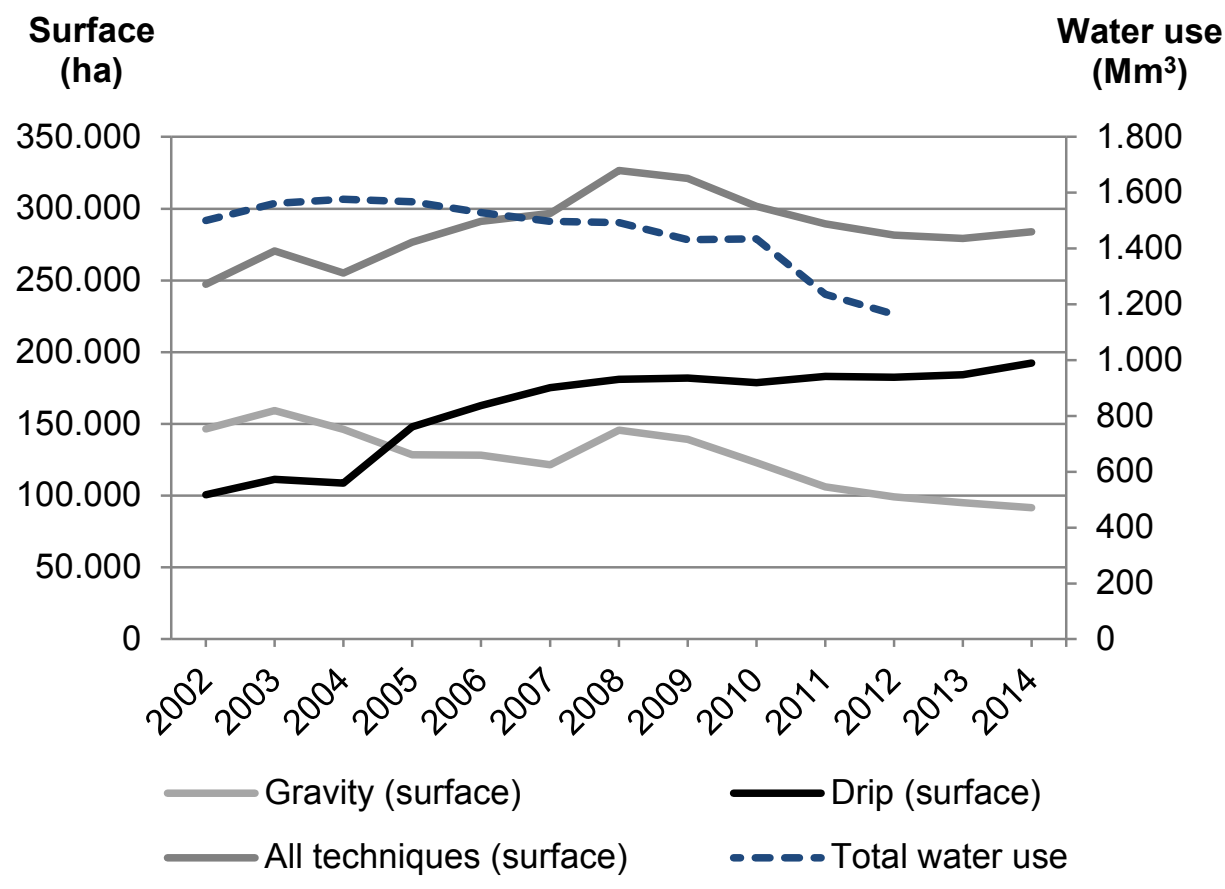

Figure 1.2. Evolution of irrigated surface by irrigation method and total water use. Source: Survey about surface and crop yield (ESYRCE) 2002-2014 (MAGRAMA, 2015a) and survey about water use in the agricultural sector 2001-2012 (NSI, 2012).

The shift on water policy for the public promotion of drip irrigation occurs in 1994, determined by a context of water scarcity (due to the severe drought occurred in 1990-1995) and after the failed 1993 National Water Plan, in a context of political

5. Spain has a highly decentralised system of administration. There are 17 autonomous regions (including Valencia) and each one has a regional government based on a parliamentary system with a legislative assembly. 
uncertainty. In this situation, the Regional Government passed the Valencia Region Irrigation Plan showing a clear commitment to increase efforts to save and reuse water, and also to improve agricultural water use efficiency (Sanchis-Ibor et al., 2016). The apparently contradictory approaches of combining both supply and demand oriented management measures, was a political move towards showing that important efforts were being made by Valencian farmers to save water. This approach justified, and encouraged, a discourse to claim for additional resources from inter-basin water transfers. In this context, the implementation of drip irrigation was part of a strong discourse of promotion of irrigation linked to 'modernity'.

\section{Evolution of water use in the Region of Valencia}

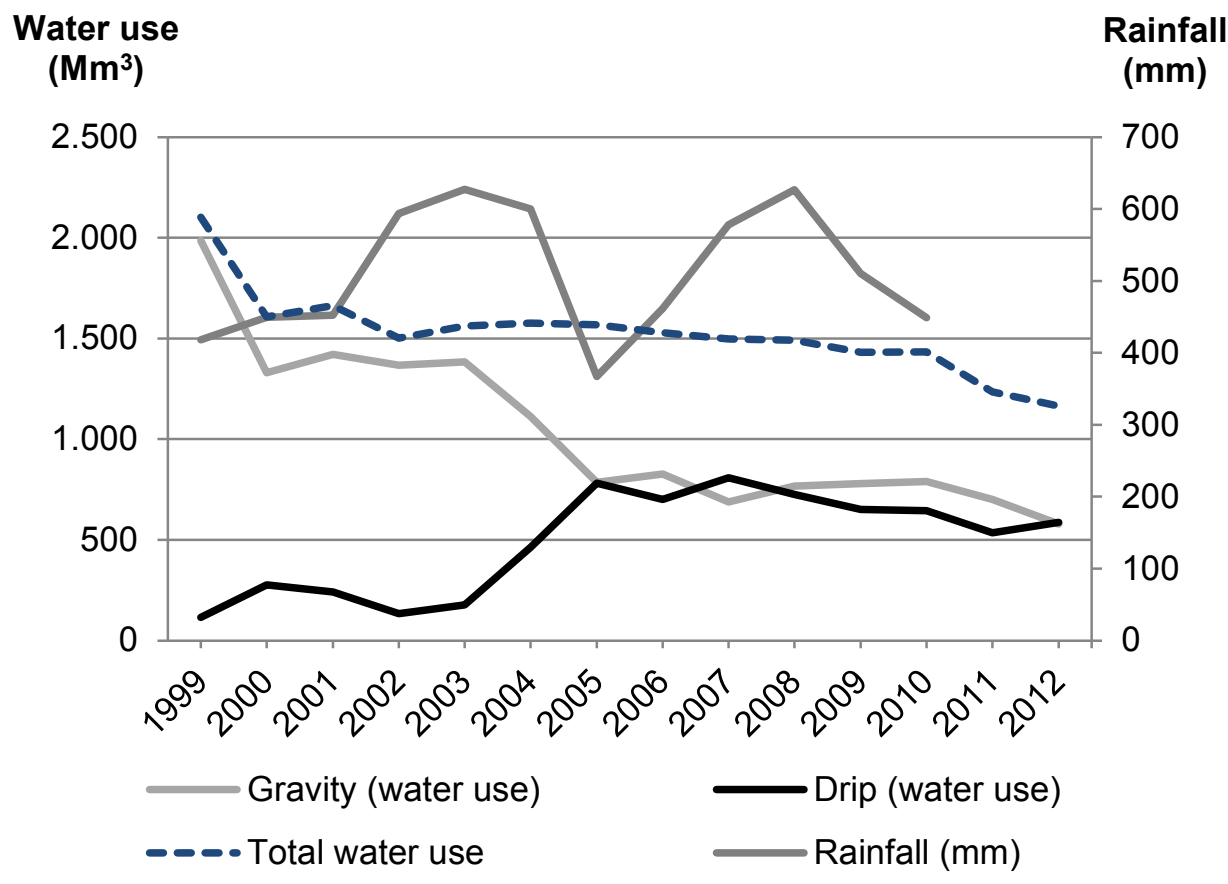

Figure 1.3. Evolution of water use by irrigation method and total water use.

Source: Survey about water use in the agricultural sector 2001-2012 (NSI, 2012) and monthly rainfall for the Júcar Basin (MAGRAMA, 2015b).

Even though it has been previously mentioned the deficiency of the existing data, Figure 1.2 shows the tendency of the surface irrigated by the main irrigation methods in the Valencia Region. It shows a decreasing tendency on the total irrigated surface since 2008 that has continued until 2013. 
Figure 1.3 shows the evolution of water use by technique. In drip irrigation the tendency is coherent with the increase in irrigated surface, although since 2007 the irrigated surface has increased meanwhile water use has decreased. In gravity irrigation, the decrease on water use seems only to be partly explained by the decrease on irrigated surface. In addition, the low value of rainfall in 2005 may have also determined a tendency of a lower consumption in the following years.

The formulation and implementation of more appropriate policies require a better understanding of transformations involved by drip irrigation adoption. In many cases, drip irrigation is associated with high-profit precision agriculture rather than collective management and family farming (van der Kooij et al., 2015). In this sense there is relatively few literature focused on the adoption of drip technologies or practices at collective rather than at individual level. This subject is relevant in the Spanish context, where there are more than 7,000 registered WUAs, and farmers into WUAs share a water allowance and have devised institutional arrangements for collective action. However, institutions need time to be defined, to get in shape, and to adapt to the needs of users. Therefore, drip irrigation is a relatively recent change and the process of transformation is at an initial stage in many cases.

\subsubsection{The Water Framework Directive}

The EU Water Framework Directive 2000/60/EC (WFD) is the common European framework in the field of water policy, in force since year 2000. It establishes a legal framework for the protection of water. Its objectives include the prevention and reduction of pollution, promotion of sustainable water use, improving the aquatic environment and water dependent ecosystems and mitigating the effects of floods and droughts. In order to do so, Member States had to devise river basin management plans including a Programme of Measures, aimed at achieving the 'good ecological status' of all water bodies.

The WFD is a considerable change in the European water legislation, and it requires a big turn in water management, especially in Mediterranean countries. Mediterranean countries are characterized by aridity, around $70 \%$ of agricultural water use, recurrent floods and droughts, and long tradition of supply-side management (Avellá et al., 2009). The context of many European countries is mostly characterized by water quality problems; meanwhile Spain has significant problems of both quantity 
and quality of water.

In the Programme of Measures of the Draft Júcar District Management Plan 2015-2021 (the final version has not been released yet), the agricultural water demand management measures include mostly the ongoing plans consisting on the implementation of drip irrigation. Their objective is to reduce pressure by water use extraction, and to promote efficient and sustainable water use. The draft mentions that during the planning cycle 2009-2015, $405 \mathrm{M} €$ have been invested for this purpose. For the period 2016-2027, the planned investment adds up to $580 \mathrm{M} €$ (23\% of the total budget of the Programme of Measures).

However, the proposed irrigation 'modernization' plans are not presented in the detailed list of measures to achieve quantitative good status associated to the different water bodies that do not comply with the objectives. Hence, they are not linked to its expected impacts, one of the purposes of the WFD. The justification provided is that they are presented separately due to its relevance. However, this choice makes more difficult to link the measures with its expected effects. According to the plan, the expected effects are: saving of water resources, due to the increase in water use efficiency, and the improvement of water quality, due to the reduction of fertilization application and the use of drip irrigation. The plan states "the improvement of transport, distribution and application efficiency produce a direct saving on the gross volume needed to supply irrigation systems" (JDWA, 2014b, p. 90). This assumption is used for the cost-efficacy analysis, although the plan acknowledges in case net water savings would be considered the resulting numbers would be significantly different.

One of the difficulties in implementing the WFD has been how to deal with uncertainty, especially regarding the expected efficacy and cost of these measures (Gómez-Limón and Martin-Ortega, 2013; Raadgever et al., 2011). In this plan, the uncertainty regarding the effects of implementing drip irrigation seems not to have been deeply considered, as it is clearly assumed that technological change will entail an increased efficiency and, in turn, the increase in efficiency will be directly translated into water savings. These assumptions have already been criticized for the Spanish National Irrigation Plan.

In addition, meanwhile in the last 20 years there was a shift towards demand-side management in Spanish water policy, since the approval of the EU Water Framework Directive investment has been both oriented towards supply-side management measures 
(the 'Plan AGUA', the Júcar-Vinalopó water transfer and the supply-side measures included in the river basin management plans) and demand-side management (the Spanish National Irrigation Plan) (Avellá et al., 2009).

\subsection{Research objectives and questions}

The aim of this thesis is to analyze how farmer-managed systems adapt to the changes related to the incorporation of new water resources and drip irrigation technologies, two of the main recent changes irrigation management in the Valencia Region.

The main objectives guiding the research undertaken involve:

- First, to study the underlying operating principles in the traditional irrigation system of the Huerta of Valencia and their similarities with Trawick's model (2001, 2008). In this respect, special attention is given to the integration of groundwater and treated wastewater water, which in recent decades have become increasingly important to the farmers of the Huerta and have been integrated into a single system. Ultimately, the use of those additional resources in adapting to the recent drought occurred during 2005-2008 is assessed on the basis of insights gained in the previous steps.

- Second, to analyse the reasons of drip irrigation adoption and assess the institutional and management changes occurred in the organizations in charge of managing irrigation as well as farmer's perception. The attention is placed in combining changes in institutions and management with farmer's and manager's perspectives in order to discuss them in the context of community management and irrigation policy. 
Three studies are reported here that provide answers to the following specific questions:

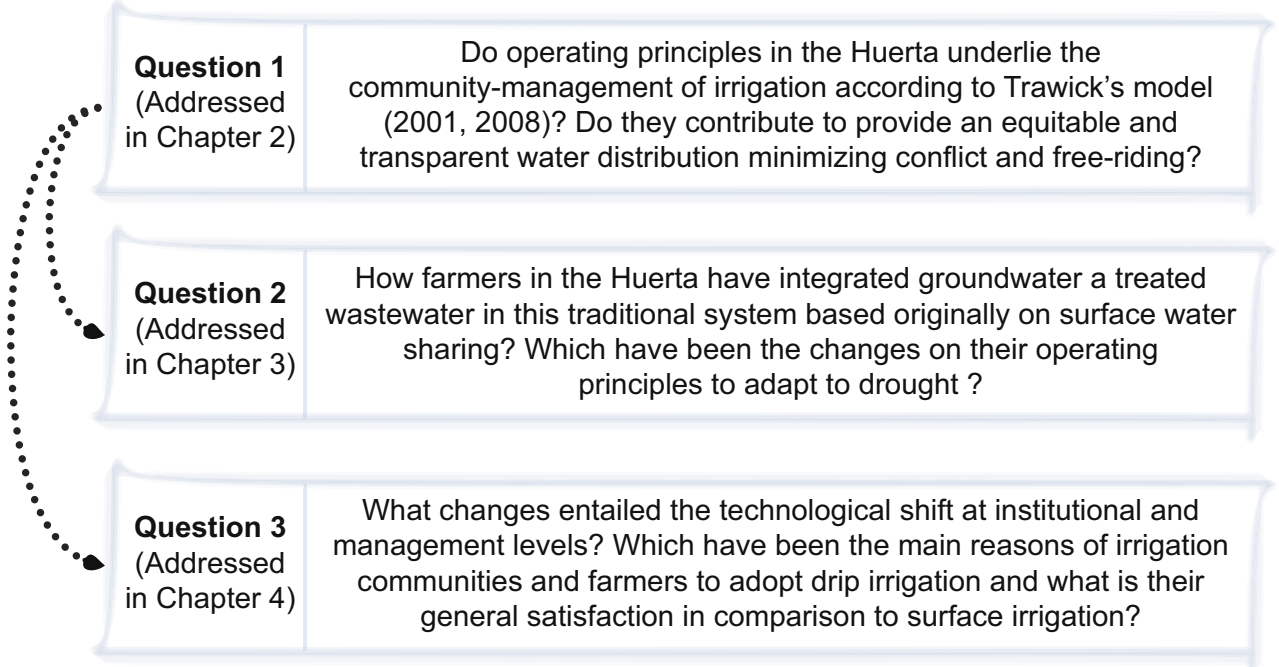

Figure 1.4. Research questions.

This work can be considered interdisciplinary, in the sense that the analysis combines approaches from several disciplines (Mollinga, 2009; Pohl, 2005). The organization of irrigation cannot be only considered from either a technical or a social sciences approach but is in interface between approaches, in the limit of the disciplines, linking issues, problems and research styles from different fields, and crossing interests. Besides, the case study approach used in the thesis aims at having a wide and detailed knowledge of the specific situations, looking at them in a real-world context, allowing for an intensive analysis in order to explain the complexity of the case (Eisenhardt and Graebner, 2007). The gained insights are unique and specific but at the same time they can be representative of other similar cases. In addition, the methods used are mostly qualitative aiming at exploring the perspective of users and managers as well as water management practices in the context framed by the main research questions.

\subsection{Overview of the thesis}

The thesis is structured in three main chapters that elaborate in the research questions mentioned above (Figure 1.4). Two of these chapters are related with traditional gravityfed irrigation (Chapters 2 and 3) and one with transformation to drip irrigation (Chapter 
4). They are followed by a general discussion (Chapter 5) and the conclusions (Chapter 6). The outline of the thesis is as follows:

Chapter 2 presents the results of comparative fieldwork on the Huerta of Valencia, a successful community-managed irrigation system of medium scale, based on the sharing of surface water. One governed collectively by thousands of small farmers, organized into 10 autonomous but highly interdependent irrigator groups. The study tested a model identified previously in research on successful systems of much smaller scale in Peru, a set of principles of operation that, when affirmed by farmers and obeyed as collective choice rules, interact to create equity among water rights and transparency in water use in an unusual way. The authors show that a nearly identical set are at work in all 10 WUAs of Valencia, revealing the unique manner in which these work together to promote successful and sustainable cooperation, both within and between the user groups, and arguing that their presence in Spain and the Andes is indicative, not of diffusion from one continent to another, but of independent invention. These principles together laid the foundations for separate Andean and Arab-Andalusian hydraulic traditions, which were often manifested locally in robust and equitable systems of the same general type, here called the moral economy of water. This kind of communal system appears to have emerged repeatedly, and often independently, in a great many other locales and settings throughout the world; its adaptive dynamics are shown to be of great relevance to small farmers today as they face the growing scarcity of water being induced by population growth and by climate change.

Chapter 3 explores the underlying operating principles in the irrigation system of the Huerta of Valencia. Successful farmer-managed irrigation systems are known to exist in various parts of the world, and they are generally based on the sharing of surface or river water. However, it is unusual to find examples of both "integrated" and "adaptive" agricultural water management. This chapter describes how one of the most famous systems, the irrigation system of the Huerta (vegetable garden) of Valencia in Spain, has integrated ground and treated wastewater use. It analyses the conjunctive use of every kind of resource and how this was crucial in adapting to the recent drought occurring between 2005 and 2008. Several operating principles, such as autonomy, contiguity, uniformity and proportionality, have been identified in previous research and shown to govern the allocation and use of water in different parts of the world, including Valencia. These principles produce conditions of equity and transparency. In order to investigate 
the perceptions of stakeholders in Valencia, interviews were conducted with farmers and the management boards of WUAs and Groundwater User Associations (GUAs). The results show that the existing supplementary resources, such as treated wastewater or Drought Emergency Wells, do not drastically change the way that the farmers manage the system. The main difference occurs in the regularity of the supply. On the other hand, the principles of autonomy, proportionality and transparency are also present in the ordinary use of groundwater from GUAs, although proportionality is defined differently in some GUAs. The farmers follow clearly defined rules, which produce an equitable and efficient use of the resource and create transparency. Results show that both existing organizations have devised a community-based system that is successful at managing water resources.

Chapter 4 puts the spotlight on the transformation that occurred with the shift from surface to drip irrigation, looking at three case studies in Valencia. We analyse the reasons for shifting to drip irrigation, and assess the main changes that have occurred regarding the management of this technology. In order to assess these changes, interviews were conducted with farmers and the managers of WUAs. The main reasons managers of WUAs mentioned for adopting drip irrigation were water conservation and convenience for farmers. In contrast, the main reasons farmers gave for adopting drip irrigation were because they had been obliged by the WUAs to do so. In the three studied cases, there has been a centralization process affecting irrigation management, the merging of the previously existing associations of farmers, or management of different water resources. The irrigation and fertigation practices studied show how farmers and WUAs have adapted the technology to their specific situations. However, management of fertilization seems to be complex to deal with on a collective level due to the varying expectations of farmers. Even though the important technological changes entail a remarkable change in collective water use and management, they did have not adapted their bylaws to the new irrigation method. However, new irrigation rules have been implemented. In addition, most of the farmers interviewed claimed to be satisfied with drip irrigation.

In Chapter 5 the implications of the previous chapters are discussed together and some limitations are also considered. Additionally, some aspects of irrigation management and governance are compared and discussed in a more detailed manner for the case of the traditional WUAs included in previous chapters. In addition, the changes 
related to the introduction of drip irrigation technologies and new water resources are further compared. The two processes present challenges for irrigation organization. However, the integration of new water sources has been gradual and does not entail major changes on self-organization. By contrast, drip irrigation promotes a fundamental institutional change. The collective implementation requires both individual and collective strategies (centralization) to deal with change. However, the agronomic focus of such projects may have a disruptive effect on self-organization if this new communitybased drip irrigation does not manage to adapt and include broader aspects of irrigation management beyond purely agronomic factors.

Lastly, Chapter $\mathbf{6}$ draws the main conclusions and provides some final remarks. 


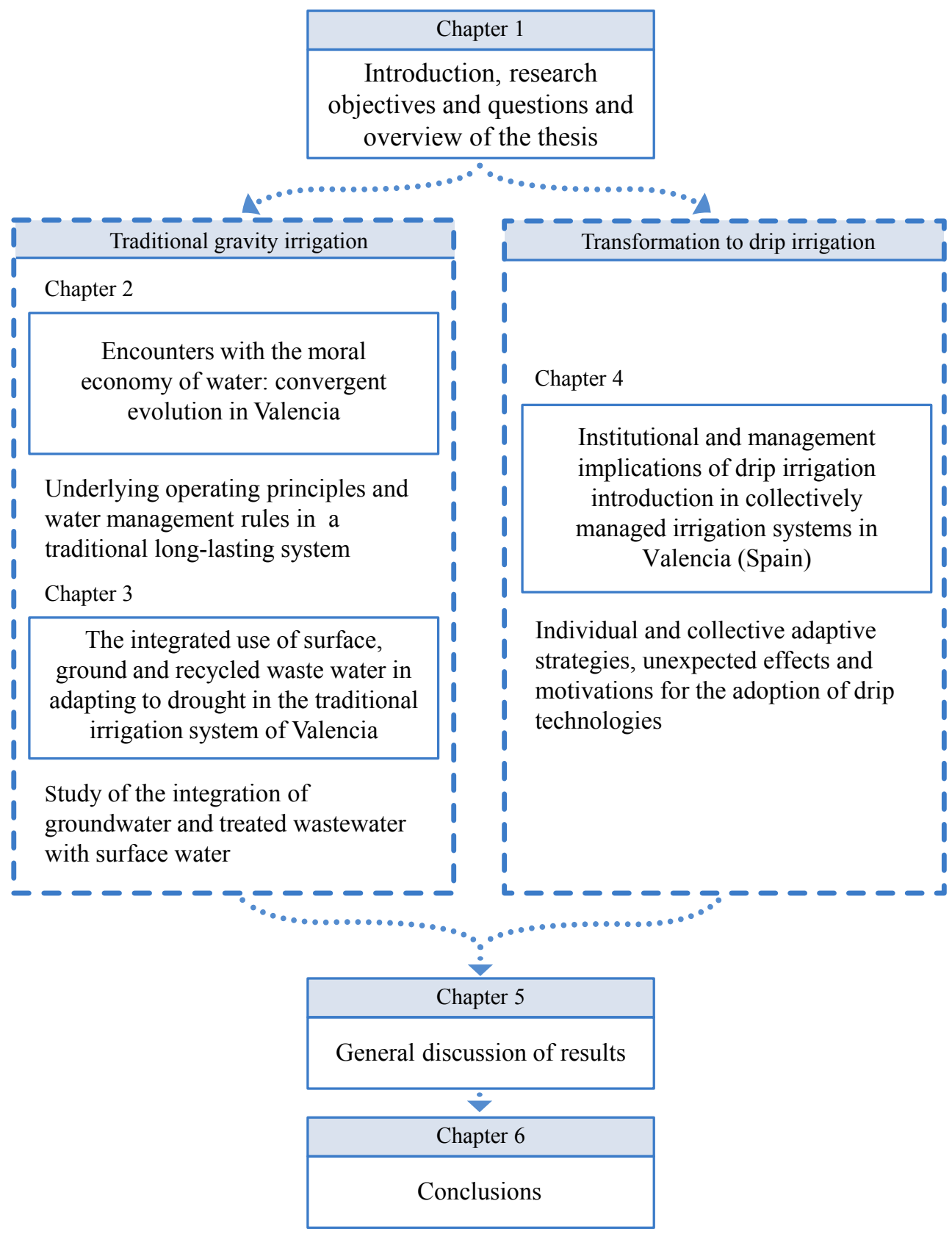

Figure 1.5. Structure of the Thesis. 



\title{
Encounters with the Moral Economy of Water: Convergent Evolution in Valencia
}

\author{
Trawick, Ortega-Reig and Palau-Salvador (2014), \\ WIREs Water, 1 (1), pp. 87-110. ${ }^{6}$
}

\subsection{Introduction}

As the population expands during the next century and the planet continues to warm, the amount of water available for human use will decline rapidly, further advancing in its present trend. The impact will be felt most strongly in irrigation - currently responsible for approximately $70 \%$ of total water use - where a growing shortage is either already present, as in many countries of the global South, or looming on the horizon to threaten long-term food security for the planet as a whole. An irrigation system is, theoretically, capable of adapting to this, consisting of some components that are self-organized, such as the water-user groups that farmers typically form, and others that are intentionally designed, such as the rules that specify how the resource will be utilized and shared by them under changing hydrological conditions. The special fascination of anthropologists and other social scientists with the technology is therefore not surprising; irrigation can, and often does, form the core of an especially dynamic kind of village-based agricultural society, one that provided the foundation upon which many early hydraulic civilizations were built.

Of particular interest, given today's impending water and food crisis, are robust systems (Anderies et al., 2004) having the capacity to maintain desired characteristics even in the face of environmental fluctuations such as the scarcities caused by seasonal low water and by periodic droughts, extreme events that are predicted to increase in frequency, duration, and scope during the coming decades (Burke et al., 2006). This use of an engineering term in reference to 'systems' having unique cultures and histories may

6. This is the accepted version of the following article: Trawick, Ortega-Reig and Palau-Salvador, Encounters with the moral economy of water: convergent evolution in Valencia, WIREs Water, 1 (1), pp. 87-110, 2014 which has been published in final form at doi: 10.1002/wat2.1008. 
be distasteful to some people, but the concept itself - one closely akin to resilience - has a theoretical and practical significance that can hardly be denied.

Another type of system has received a great deal of attention in recent years: those run according to rules and procedures established collectively by local farmers themselves, rather than by government bureaucracies. Throughout the world a large number of case studies have been done of community-managed systems, providing the primary data for subsequent comparative analyses aimed at determining what features these local hydraulic societies have in common (Agrawal, 2002; Baland and Platteau, 1996; Maass and Anderson, 1978; Ostrom, 2005, 1992, 1990; Tang, 1992). A trait shared by some of them, but by no means all, is a type of success compatible with robustness.

Some systems show a remarkable capacity to cope with both moderate and severe water scarcities while maintaining two social characteristics that are now accepted, at least by some authors (Ostrom, 1992, 1990; Tang, 1992; Trawick, 2010, 2008, 2001b), as indicators of desirable and apparently sustainable outcomes in irrigation: 1) all people who are entitled to receive water get their full share during each distribution round, including the "tail-enders" along each canal (an indicator of equity or fairness); and 2) the rate of water theft, the most disruptive form of cheating and free-riding, is extremely low or even virtually nil (an indicator of effective monitoring and transparency).

The most important questions about these locally governed systems have yet to be fully answered, however, ones that are crucial in explaining their success and their capacity to adapt. What institutions or rules enable farmers to cope collectively with climatic fluctuations; and which of these, if any, do most successful systems have in common? If farmers consider equity and transparency to be desirable characteristics, are those outcomes defined differently and achieved through very diverse rules in various environmental settings, as some authors argue (Boelens and Dávila, 1998; Boelens and Hoogendam, 2002; Boelens and Vos, 2012; Mosse, 2006a, 2006b, 2003)? Or is a single set of institutions capable of creating them, or helping to create them, in systems of widely different scales and levels of complexity, and of maintaining them during droughts? In other words, is there a single best or 'optimal' way of organizing communities to cope with fluctuation and scarcity, in different settings and across different scales?

The research to be discussed here was comparative and ethnological in that it attempted to answer these questions by determining if a particular set of principles, 
previously shown to govern several robust and successful systems in one part of the world - the Peruvian Andes (Trawick, 2005, 2003a, 2003b, 2001a, 2001b, 1994; Treacy, 1994a, 1994b) - also exists in a well-known system on the Mediterranean coast of Spain, a region notorious for having a number of impressive systems of this general type. Perhaps the most famous of all is the Huerta or garden of the city of Valencia, the main focus of this study. The goal was to determine if equity, transparency, and robustness are achieved in the same way there, in a multi-community system of medium scale, as in the aforementioned systems in Peru, which are small in scale and belong to tiny peasant villages in remote corners of the Andes.

A test of this hypothesis was interesting for several reasons, not least the fact that these local irrigation societies almost certainly evolved independently of each other, having emerged long ago as distinct Andean and Islamic hydraulic traditions (Trawick, 2010, 2008, 2003a, 2001a). If the rules and principles governing them today are indeed highly similar, as we will argue here - displaying striking parallels among systems that otherwise differ in many important respects - then the Valencian and Peruvian systems document one of the most striking examples of convergent social evolution ever identified in the ethnographic record. This convergence among societies evolving independently in different parts of the world is unprecedented and has important implications for social scientists as well as farmers, especially for small farmers who are struggling to cope with the growing scarcity and unpredictability of water being brought on by population growth and by climate change.

\subsection{Infrastructure and social organization in the Huerta, a multi-community system of medium scale}

The canal system of Valencia, on Spain's central Mediterranean coast, has been the focus of several classic studies in the irrigation literature (Glick, 1970; Maass and Anderson, 1978; Ostrom, 1990). Long regarded to be highly successful, and known to be extremely old, the system is governed democratically by approximately twenty thousand small farmers organized into ten relatively autonomous irrigator communities (or WUAs), whose apparently Islamic institutions are thought to date back to the time before the expulsion of the Moors in the medieval period. Here, the antiquity of the canal infrastructure and its communal mode of governance contrast sharply with the modern cosmopolitan setting: a city of approximately a million people, much of whose 
food is supplied by the Huerta or garden, a term used locally to refer to the canal system as a whole.

The famous Water Tribunal that governs the system has been meeting publicly every Thursday at mid-day in the city center - in the Apostles' Door of the main cathedral - for over seven hundred years ${ }^{7}$, to settle any disputes between farmers over water (Glick, 1970). This solemn oral court is impressive but often merely ceremonial, as the black-robed judges - elected leaders (Sindicos) of eight of the local WUAs - rarely have any formal complaints to consider. The frequency of conflict among farmers is amazingly low, as we will see, and this has clearly been the case for a very long time. Today the weekly ritual is invariably watched by hundreds of tourists, people drawn to Valencia by events like the its Formula One Grand Prix, the 2007 Americas Cup yacht race, or even the 2007 release of the Fourth Assessment Report of the UN's InterGovernmental Panel on Climate Change.

The canal network presently serves an area of 8,804 ha, land watered with the flow of the Turia River, whose volume today is closely regulated and smoothed out by three upstream dams. Nearly half of this land (3,792 ha) belongs to the members of the nine WUAs that participate in the Water Tribunal (see Figure 2.1 and Table 2.1), groups which are autonomous in the sense that each has its own written rules for using the river water, ordenanzas that can theoretically be changed at any time. These institutions have in fact been remarkably stable for centuries, and they turn out to be highly similar from one WUA to the next. A tenth and very large upstream WUA, called the Real Acequia de Moncada - which lies within the Huerta but does not participate in the Water Tribunal ${ }^{8}$ - shares the river flow through the uppermost main canal to irrigate 5,012 ha, or slightly more than half of the total area served.

7. The Tribunal meets weekly, since water use is supervised throughout the entire year. Although there are ten canal communities (or WUAs) in the Huerta, one of them, Moncada, does not participate, having its own Tribunal. Of the remaining nine, only eight are directly represented on the water court: the ninth, Xirivella, has its own Sindic but is represented in the Tribunal by the Sindic of Mislata, whose main canal it shares.

8. The area covered by the nine WUAs participating in the Water Tribunal is also referred to in other chapters as La Vega de Valencia or La Vega (the meadow of Valencia). This term is used to distinguish them from the neighbouring WUA of the Real Acequia de Moncada. 


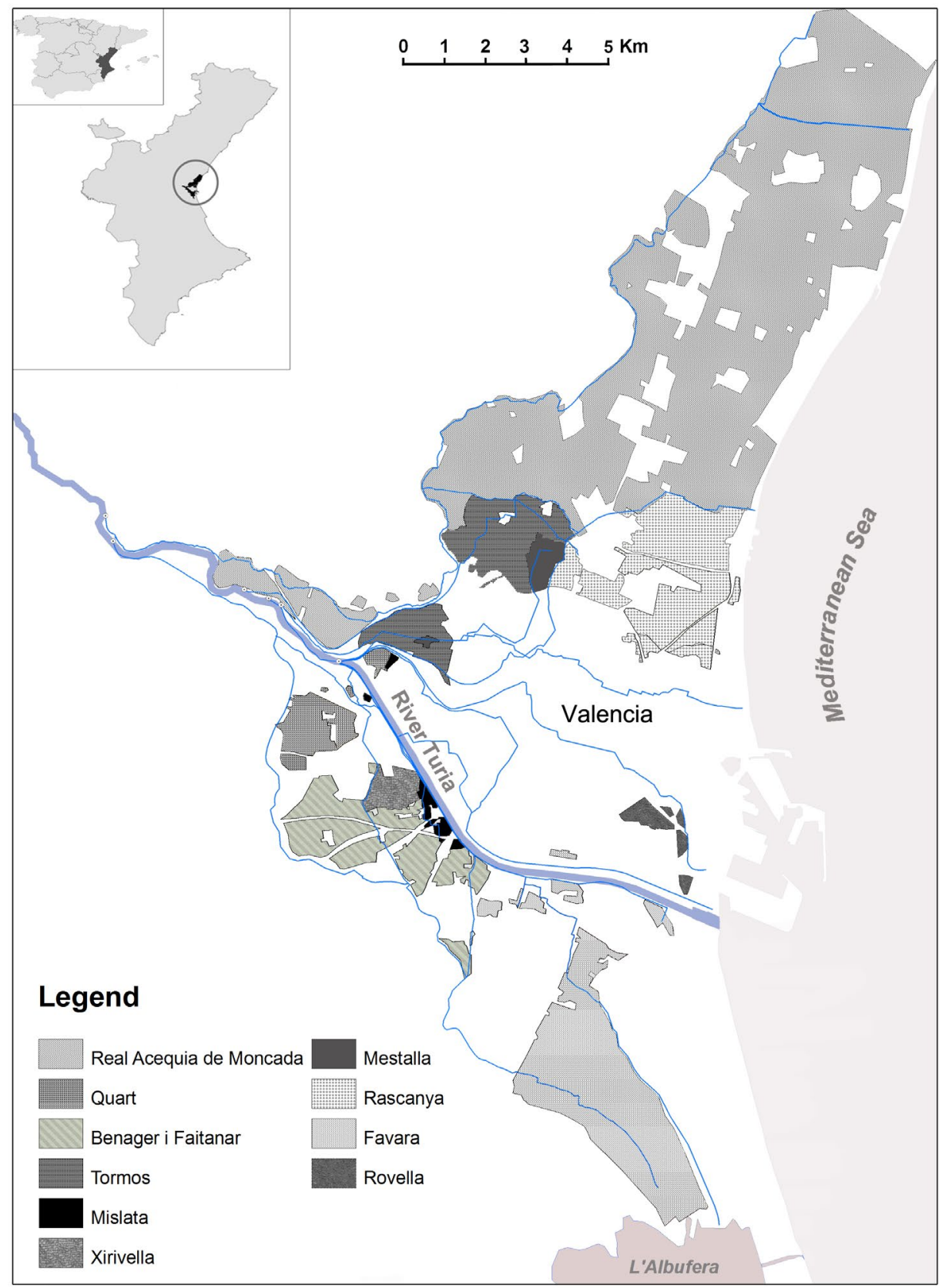

Figure 2.1. WUAs in the Huerta of Valencia.

The water shares drawn by each WUA from the river are fixed percentages of the total flow, diverted into the eight main canals by permanent weirs called azuds, an 
Arabic term dating back to the system's construction. The size of each flow was originally determined by the land area irrigated, service areas that until recently remained quite stable. In the last forty years, however, most of the WUAs have lost substantial amounts of land due to urban growth (see Table 2.1). Although their traditional allocations of river water have yet to be reduced accordingly, local farmers rightly feel threatened by this ongoing encroachment.

A less serious threat, and one that Valencians have longer experience in dealing with, is drought, the frequency of which is widely acknowledged to be increasing with climate change. Within most of the ten WUAs (but not all of them), local well societies ${ }^{9}$ were established gradually during the last century in order to assist in coping with it, cooperatives formed by farmers who pooled their money in order to drill into the underlying aquifer and thus share both the costs and benefits of additional water coming from the ground.

These groundwater irrigation groups - whose existence and importance were noted previously by Maass and Anderson (1978, p. 16) and Ostrom (1990, p. 71) today number in the hundreds, groups whose membership overlaps in each case with that of an encompassing WUA (Ortega-Reig, 2009). These essentially private irrigation societies are not a part of the Huerta's long tradition of communal water management, but they have been strongly shaped by its institutions, as we will see below, and they rest on the hydraulic and social foundation thus provided. The societies make it possible to integrate the use of the two sources of water, and they turn out to play a vital role in keeping commercial crop production viable during periods when the river water is scarce.

Because the WUAs have their own flows drawn from the river and their own rules for using that water, the Huerta appears at first glance to be a set of largely independent small-scale or "indigenous" systems, i.e., ones of less than 1,000 ha (Hunt, 1988; Mabry and Cleaveland, 1996). However, two of the user groups - Favara and Moncada - are substantially larger and technically of medium scale, while two others Quart and Benager-Faitanar — rely on a single weir and divide the flow of a main canal to irrigate nearly that amount of land. To classify Valencia as a set of separate small-scale systems is to overlook these complexities and also ignore the high level of cooperation

9. The term Groundwater User Associations (GUAs) or well associations is also used to refer to the same type of associations in other chapters of this thesis. 
routinely required — as we discovered in the research — to coordinate the timing of all the WUAs' water use so that they can irrigate together on a single cycle.

Table 2.1. Service areas of WUAs in the Huerta of Valencia in 2009 and 1965.

\begin{tabular}{|c|c|c|}
\hline & $\begin{array}{l}\text { Irrigated surface } \\
\text { in } 2009 \text { (ha)* }\end{array}$ & $\begin{array}{l}\text { Irrigated surface } \\
\text { in } 1965(\mathrm{ha}) * *\end{array}$ \\
\hline Canal of Quart (shared) & 939 & 1526 \\
\hline 1) WUA of Quart & 324 & $?$ \\
\hline 2) WUA of Benàger - Faitanar & 615 & $?$ \\
\hline Canal of Mislata (shared) & 165 & 769 \\
\hline 3) WUA of Mislata & 65 & $?$ \\
\hline 4) WUA of Xirivella & 100 & $?$ \\
\hline \multicolumn{3}{|l|}{ Have own main canal } \\
\hline 5) WUA of Tormos & 600 & 945 \\
\hline 6) WUA of Mestalla & 116 & 900 \\
\hline 7) WUA of Favara & 1057 & 1054 \\
\hline 8) WUA of Rascanya & 840 & 720 \\
\hline 9) WUA of Rovella & 75 & 415 \\
\hline Subtotal of communities in Water Tribunal & 3792 & 6329 \\
\hline WUA of Real Acequia de Moncada & 5012 & 3190 \\
\hline Total of all permanently irrigated lands & 8804 & 9519 \\
\hline Extremales (land with rights to surplus water only) & 563 & 6539 \\
\hline Favara & 359 & 2056 \\
\hline Rascanya & 0 & 580 \\
\hline Rovella & 204 & 93 \\
\hline Real Acequia de Moncada & 0 & 3810 \\
\hline Total Huerta lands & 9367 & 16058 \\
\hline
\end{tabular}

*Source: GIS data from Centro Valenciano de Estudios sobre el Riego. Published in the Plan de Ación Territorial de la Huerta Valencia (PATH), table 2.2-3, p. 54, http:/ / cam.gva.es/condenido/62478/cas/I MI 2-2.pdf

**Source: Maass and Anderson (1978)

The Huerta stretches across an extensive delta and floodplain that underlies the growing city, fanning out near the point where the Turia River empties into the Mediterranean Sea. The rich alluvial soils and the temperate and largely frost-free climate enable farmers to produce two or three crops per year, much of it for sale in local, national, and even global markets. The chief products, which typically are also consumed daily by the landowning households, are potatoes, onions, melons, a wide array of garden vegetables, and even a local variety of paella rice, together with the oranges for which the surrounding region is famous. Local agriculture is thus heavily 
commercialized, even though the farms are quite small in nearly every case. In their classic study published more than thirty years ago, Maass and Anderson (1978, pp. 11,40 ) noted that fewer than $1 \%$ of the farms were bigger than 5 ha, while $83 \%$ were smaller than 1 ha, a highly fractured minifundia pattern that still prevails today, as shown in Table 2.2.

Table 2.2. Pattern of landholdings in the WUA of Real Acequia de Moncada in 2009.

\begin{tabular}{cccccc}
\hline Size Range & $<1$ ha & $1-3$ ha & $3-5$ ha & $>5$ ha & Total properties \\
\hline Number of properties & 9196 & 537 & 26 & 14 & 9773 \\
$\%$ of all landowners & $94.10 \%$ & $5.50 \%$ & $0.03 \%$ & $0.01 \%$ & $100 \%$ \\
\hline
\end{tabular}

Valencia is therefore a multi-community system of medium scale, but it remains a smallholder system, like the previously-studied examples in Peru, one composed of household production units that, in terms of their size and labor organization, closely resemble those that generally prevail today in developing countries. The similarity ends there, however; for if Valencia's farms are overwhelmingly of this 'peasant' type, they are certainly among the most productive such farms to be found anywhere in the world. The droughts are a major handicap, but the Huerta's farms remain extraordinarily productive in spite of them, mainly because people cooperate so effectively in adapting and in sharing the impact of scarcity.

\subsection{Methods used in the fieldwork}

The research was conducted in four distinct periods: an initial one during a five-month stint in the spring and summer of 2004 (Trawick, 2010, 2008), a second in June and July of 2009, shortly after the end of a severe three-year drought (Ortega-Reig, 2009), a third extending throughout 2010 (Ortega-Reig, 2011), and final one in the spring and summer of 2013. The early fieldwork focused on testing the hypothesis of convergent evolution; however, the drought's onset in 2005 provided an opportunity to study the system's robustness in adapting to fluctuation and severe scarcity, thus encouraging a continuation. Yet there were other reasons why a close re-examination of the rules and principles governing irrigation in the Huerta was necessary.

First of all, the work of Maass and Anderson (1978, p. 26), although without peer in the irrigation literature, had provided crucial data that needed further verification 
and updating. Maass's account had argued that the system was both equitable and efficient, with water rights based on a principle of "proportionate equality"; but it did not document the frequency of irrigation for the various user WUAs, or for the thousands of individual farmers, at different times of the year. His definition of that term - one later shortened and clarified by Ostrom (Ostrom, 2005, 1992, 1990) to the more familiar "proportionality of costs and benefits" - did strongly imply that the watering frequency was the same for everyone, as it is in the previously studied systems in Peru. But such uniformity was not defined as a basic principle in either of those accounts, in a system where water distribution was shown to be, from the viewpoint of an outside observer, extremely complicated, with irrigation occurring simultaneously within a single canal community (or WUA) in as many as thirty different places.

There was thus a need to confirm that this principle - the most important one driving the dynamics of the aforementioned model - was operating, and to show that it was recognized to be significant by the local farmers. This would amount to verifying, through interviews, that the system is indeed effective in providing every entitled person with their rightful share during each distribution round - a task that, it should be noted, remains unfinished for most of the 'successful' systems reported to date in the world literature on irrigation.

A similar criticism applied to the monitoring of water use at the level of the field and the 'individual' irrigator. The importance of mutual monitoring by the farmers themselves was overlooked by Maass and Anderson, who implied that vigilance within the system was handled adequately by the distributors and guards of the water, the Guardas, full-time professionals who are employed by each irrigator group. Ostrom (1990, pp. 73-75), in later calling overdue attention to it, had sustained some of the earlier observations of Glick (1970) in his classic historical study. Both Glick and Ostrom had noted that the level of monitoring by the farmers of each other was very high, also observing that this was in part made possible by the fixed order of people's turns along each canal. But neither author had apparently had the opportunity to ask any farmers about this. If a model derived from much smaller systems in another part of world was to be tested in Valencia - a model based on clearly-defined principles of equity and transparency- then the effort obviously required a closer look.

Maass's description, which provided most of the data used later by Ostrom, had relied heavily on earlier sources published in Spanish, many of them official records and 
publications of the ten WUAs. He had apparently also interviewed some people, but provided no information about this, giving the impression that the primary data came either from those earlier published sources or from the elected leaders of the user groups. Recent critiques prominent in the literature have shown that the rules supposedly governing communal irrigation systems often turn out to be idealized representations that bear little resemblance to social reality (Mosse, 2006a, 2006b, 2003). Those flattering images can still be very useful to local water officials, especially in dealing with inquisitive outsiders. A re-study was therefore necessary, one that relied more on interviews, was explicit about sampling, and made an effort to include ordinary farmers.

Finally, there was the fact that Moncada, the largest canal WUA by far, had been neglected somewhat in the previous studies. There appeared to be several possible reasons for this, but Maass and Anderson's account (1978, p. 411) gave the impression that Moncada - which has its own set of twelve elected Sindics and even its own Water Tribunal - has distinct rules for using its portion of the river flow, especially during droughts. Luckily, an opportunity presented itself early in 2010 to extend the study to include this part of the canal system and to fill a significant gap.

Our methodology departed in interesting ways from the approach normally adopted in doing semi-structured interviews. From the start we were aware that water rights in the Huerta are complex, involving the use of both surface and groundwater under changing conditions, but that, in the case of the surface water - the foundation of the traditional system - they appeared to conform to the aforementioned model. Since our main goal was comparative and ethnological - determining whether or not that Andean model did fit local practices - a set of yes/no and multiple-choice questions was drawn up, based on the principles comprising the model, and used as a guide for the interviews. For example, one question explored whether or not the irrigation frequency is the same for all ten WUAs, and for all of the farmers in each one, whenever scarcity prevails. This was done by giving people the opportunity to agree or disagree with a statement to that effect, on a 5-point Likert scale.

Although such structured questions could perhaps be considered leading ones, which are not appropriate for ethnographic research, we used them in a novel way designed to 'open them up' and counteract this effect, making them suitable for ethnology. The goals of the discussions in each case - lengthy conversations guided through prompting by the interviewer - were to have the farmers and other participants 
choose a response to the question as stated, while also commenting on whether or not this was an easy thing to do. We found that, when used interactively in this way, even a yes/no question would usually elicit a lengthy response - typically "yes, but...", or "no, but... - and ultimately yield a lot of useful information.

Note that the questions or statements did not specify which of the water sources was being referred to: the river water or the groundwater. Instead, people were encouraged to provide that information in the process of choosing and explaining their answers. The initial choices that people made on the Likert scale were not altered in numerically compiling the results, even if the subsequent explanation indicated that it rightly should be, as happened numerous times. By using otherwise closed questions in this open-ended but structured way, we were able to deconstruct the set of rights and duties underlying irrigation today in the Huerta.

A total of 113 interviews were conducted, with local water officials - people who were either currently serving, or had formerly served, in the water-user groups - and with ordinary farmers. A purposive snowball method was used to identify the former subset, a pool of 48 Sindics (elected user-group leaders, who are themselves farmers) and Guardas (professional Water Guards, who generally are not), some of who were interviewed twice in separate samples done several years apart ${ }^{10}$. The 59 farmers were interviewed once and selected through a modified convenience sample, with most of them contacted initially in the fields while irrigating. The sample also included 6 regadores, contracted irrigators who, although not landowners themselves, derive their livelihood by performing this service on a long-term basis for local farmers.

Table 2.3. Categories and numbers of informants.

\begin{tabular}{cccc}
\hline Informants & Tribunal Communities & Moncada & Total \\
\hline Sindics & 9 & 2 & 11 \\
Guardas & 29 & 8 & 37 \\
Farmers & 33 & 26 & 59 \\
Regadores & 0 & 6 & 6 \\
TOTAL & 71 & 42 & 113 \\
\hline
\end{tabular}

Members of all ten WUAs were included in the sample, including, during the 10. The Sindics and former Sindics are farmers and landowners, as required by customary law, but are not paid a salary. The Guardas or Water Guards are full-time salaried professionals, a highly skilled position often handed down in local families, with fathers training their sons. 
final period of the research, 42 informants of both types in Moncada. The total number of farmers ultimately interviewed, including the Sindics and the appropriate Guardas, turned out to be 75 . The conversations were taped, and notes were taken in order to prepare transcripts of the interviews, which lasted from half an hour to one-and-a-half hours in every case. Trips to the canals and fields were also made, accompanying the Guardas, to observe the complexities of water distribution and to discuss the methods for irrigating the different crops.

Although we could not even begin to attempt a statistically significant sample of the nearly twenty thousand local farmers, the answers given by people were ultimately in such close agreement, and they triangulated so well with the information contained in the historical documents, the ordenanzas, and the earlier published accounts, as to provide a convincing portrait of how things are done today in the Huerta. It largely corroborated the data presented earlier by Glick, Maass and Anderson, Ostrom, and others, while providing important clarifications, updates and corrections, ones which confirmed that the hypothesized model does fit local practices.

\subsection{Results: the distribution and use of seasonal low water}

The interviews revealed that, in the management of the river water - the foundation of the local tradition - equity and transparency are achieved in the same way, by means of a nearly identical set of principles, in Valencia as in the aforementioned systems in Peru. Importantly, this generalization also applies to Moncada, so that all ten of the Huerta WUAs can be said to have converged on the same basic 'model' despite the autonomy enjoyed during much of their evolution.

The governing institutions, listed below in Table 2.4, are defined here as operating principles in order to indicate that in most cases they are derived through one small step of conceptual abstraction - a step easily recognizable to the local farmers - from one or more of the specific working rules, as explained to us in the interviews or as recorded in the ordenanzas. Despite their many differences, those rules are similar enough in the Peruvian and Valencian traditions that the institutions operating in one system and country would be easily understood by the farmers residing in the other.

Note that the principles overlap with, and are entirely consistent with, the design principles identified by Elinor Ostrom in her ground-breaking work (Ostrom, 2005, 1992, 1990) on the successful management of this particular "common-pool" 
resource, comparative work that greatly influenced and inspired our own. Our goal was merely to come up with a set of institutions that is more complete and somewhat more precise than hers, also being a bit closer conceptually to the actual working rules in each of the local systems that have been compared.

The principles in most cases specify a form of moral self-restraint that farmers routinely impose on themselves in using water under conditions of scarcity, an upper limit on consumption that helps to avoid waste of the resource, to maximize its availability, and, above all, to minimize social conflict. The principles thus reveal the moral core lying at the heart of the working rules, which appears to be basically the same in all of the local systems that have been studied. By employing this kind of analytical logic, it becomes possible to appreciate the unique way that the principles interact with each other, forming a kind of integrated whole or model that both shapes and reinforces people's inherent willingness to cooperate, as we will see below.

The principle of autonomy has already been discussed but requires some clarification. The power of the ten WUAs to set and modify their own rules was recognized by almost everyone interviewed, as shown in Figure 2.2, but also acknowledged to be limited. People are very much aware that the local user groups have long played a central role in managing their own resources, enjoying the kind of freedom that all such groups in Spain now have under the water law of 1985 and the Real Decreto Legislativo of 2001 (BOE, 2001; Gimenez-Casalduero and Palerm-Viqueira, 2007). In their previous study, Maass and Anderson (1978, p. 48) observed that this local power had not diminished, even after the State built three storage and regulation dams on the Turia River, beginning in the 1950 's, to smooth out the yearly fluctuations in the supply. But this is no longer entirely true.

The canal WUAs now function in coordination with the Júcar District Water Authority (JDWA), the bureaucracy that operates the dams. Given the beneficial service provided, they are receptive to its suggestions for improving existing arrangements for water use, within the general constraints expressed in the traditional operating principles. Hence, as Ostrom has rightly noted (2005), the WUAs operate today within a nested hierarchy of other institutions, including those introduced by the JDWA and the Spanish government. The autonomy they enjoy is a limited one, simultaneously modern - informed by hydrological science and the use of up-to-date technology and yet based largely on moral principles dating back to Islamic times. 
Table 2.4. Operating principles of irrigation under scarcity in Valencia.

Autonomy - each community has and controls its own flow of surface water, which is distributed and used according to customary rules;

Alternation or turn-taking - the sets of communities on either side of the river cooperate by alternating in extracting their assigned flows, in such a way that they irrigate together in a single cycle; their individual farmers do likewise, taking turns in order to share the resource in the same coordinated way;

Contiguity in distribution - within the communities in each half of the system (i.e. on the two sides of the river), water is distributed to fields in a relatively fixed contiguous order based only on their location, starting at the upper end and moving systematically downward, canal-by-canal and field-by-field*, until all of the eligible lands have been irrigated.

Uniformity (one component of equity or fairness):

- among rights: all entitled fields receive water with the same frequency, so that the impact of the prevailing scarcity is shared and absorbed evenly by all of them;

- in techniques: all farmers irrigate their crops in the same way, using one of two standard methods that in each case impose an upper limit on water consumption and on irrigation time, thereby creating a fairly uniform land-towater ratio throughout the canal system;

Proportionality (the other component of equity):

- among rights: in taking their allocated turns, irrigators use only the amount of water to which the extent of their land, and the specific watering technique being utilized, entitle them;

- among duties: people's contributions to canal maintenance must be proportional to the amount of irrigated land that they have, and thus to the amount of water that they use; (also between rights and duties) .

Transparency - everyone knows the distribution rules and, because the proper order of turns is fixed and contiguous along each canal, they have the ability to confirm, with their own eyes, whether or not those rules are being obeyed, to detect and denounce any violations that occur.

Boundary maintenance - any unauthorized expansion of irrigation, which would lower the frequency of water use for everyone, is prohibited.

Direct feedback on the level of free riding - the frequency of water use for everyone is determined, in a direct and obvious way to each farmer, by the extent to which people are obeying the rules.

Graduated sanctions - the penalties for rule violations are severe but vary according to the gravity of the offence.

*The use of favour water, or agua de gracia, presents a partial exception to contiguity (Maass and Anderson, 1978, p. 27), wherein the Guards shift water between canals in order to speed up irrigation in areas where it is lagging behind. But the same top-tobottom rule reportedly governs this somewhat opaque process. 
The second principle, alternation, was not recognized by Maass and Anderson as part of the normal way of operating during the dry season, but today it is. The research revealed that this arrangement, which is not entirely new, was instituted by the WUAs, by mutual accord but at the suggestion of the JDWA, in the late 1970's or early 1980 's, when it was recognized as the best arrangement for operating during seasonal low water. It is a minor alteration of the traditional procedure for adapting to drought, referred to by Maass and Anderson (1978, p. 29) as "la dobla". Importantly, the change followed an earlier move by some of the canal WUAs to extend full water rights to all of their formerly irrigated lands, including many extremales, lands that had previously been entitled only to excess or surplus water when that was available (Ortega-Reig, 2011; Sales Martínez, 1988). This seems to have been a consequence of the improvements in and stabilization of river flow that resulted from the construction of the three reservoirs, particularly that of Benageber, starting in the 1950's.

Although several WUAs agreed to the latter change, Moncada was the one that benefitted most, as revealed by the figures in Table 2.1. Far fewer extremales existed in most of the other WUAs, and the inclusion of some of them failed in those cases to counteract a contraction of irrigated land due to urban encroachment, a process that is still ongoing today. Interestingly, the major expansion in Moncada did not entail any increase in the WUA's assigned portion of the river flow, so that it did not compromise the existing rights of the other WUAs and farmers in the Huerta. Because of it, all of its farmers now have full rights to the surface water, and all of them irrigate in one coordinated cycle.

Each week, Moncada and the other WUAs lying downstream irrigate simultaneously, by dividing the river flow roughly in half. However, the nine WUAs of the inner Huerta (i.e. the members of Valencia's Water Tribunal) alternate in using their portion, with the groups on the right bank (Quart, Benàger-Faitanar, Mislata, Xirivella, Favara and Rovella) irrigating from Monday through mid-day on Thursday, and those on the left bank (Tormos, Mestalla, and Rascanya) irrigating from mid-day on Thursday through Sunday (Guinot, 2007). By taking turns in this way, all of the WUAs, including Moncada, are able to stay on the same schedule, equitably sharing the prevailing scarcity.

The principle of contiguity was recognized, at least implicitly, by all of the previous researchers, and was again vetted by almost everyone interviewed in our study (see Figure 2.2). The general rule for water distribution under scarcity in Valencia is 
"from up above to down below", but the interviews and first-hand observation revealed that there are two variations in how this contiguity principle is expressed in practice. Although a strict top-to-bottom order is followed in several cases, as in Moncada and Benàger-Faitanar, some WUAs - Quart, Tormos, Xirivella, Rascanya, and Rovella - use an inscription system to record the exact order in which their farmers will irrigate, in situations where people sometimes forfeit their turns.

Here the traditional top-down order of rights serves as the model, but before each cycle begins the farmers must write their names, on a blackboard located at the head of the canal, in order to express their intention to exercise their right and to avoid being skipped in the order. In other WUAs no signature is needed, but there the traditional rule is that each farmer must arrive at his field before the next farmer below him begins to irrigate in order to take his normal turn. If he is late in arriving he must wait, thus experiencing a small delay, but if he arrives even later, after his immediate downstream neighbor has finished, he loses his turn and must wait until the next round.

The meticulous nature of these rules helps to illustrate one of the main advantages of a contiguous watering order, which had been identified in the previous research in Peru (Trawick, 2003a, 2001a, 2001b). Several farmers noted this advantage and felt that it explains why the contiguity rule exists in all ten of the Huerta WUAs (Ostrom, 1992). As both Glick (1970) and Ostrom (1990) observed in their accounts, because field preparation and other routine chores are concentrated in one small expanse of land at a time - rather than being more spread out, as in other kinds of systems (Trawick, 2001b, pp. 21-22) - irrigation is a highly-visible, public activity. Neighboring farmers are routinely able to observe each other irrigate, and also to watch the work of the water distributor. The contiguity principle thus helps to create a highly transparent system, of which more will be said below. It also minimizes - as all local farmers seem to understand - the total surface area of canals in use at any point in time, correspondingly reducing evaporation and filtration and thereby maximizing the frequency of irrigation for everyone.

Uniformity in the watering frequency, the most important principle of all, was confirmed by the vast majority of people - with $96 \%$ either agreeing or strongly agreeing that it is the same for everyone within each WUA, and $86 \%$ affirming that it is uniform between all ten WUAs, as shown in Figure 2.3. But it was not affirmed by everyone, and here the disagreements revealed important details of how the system works. Numerous 


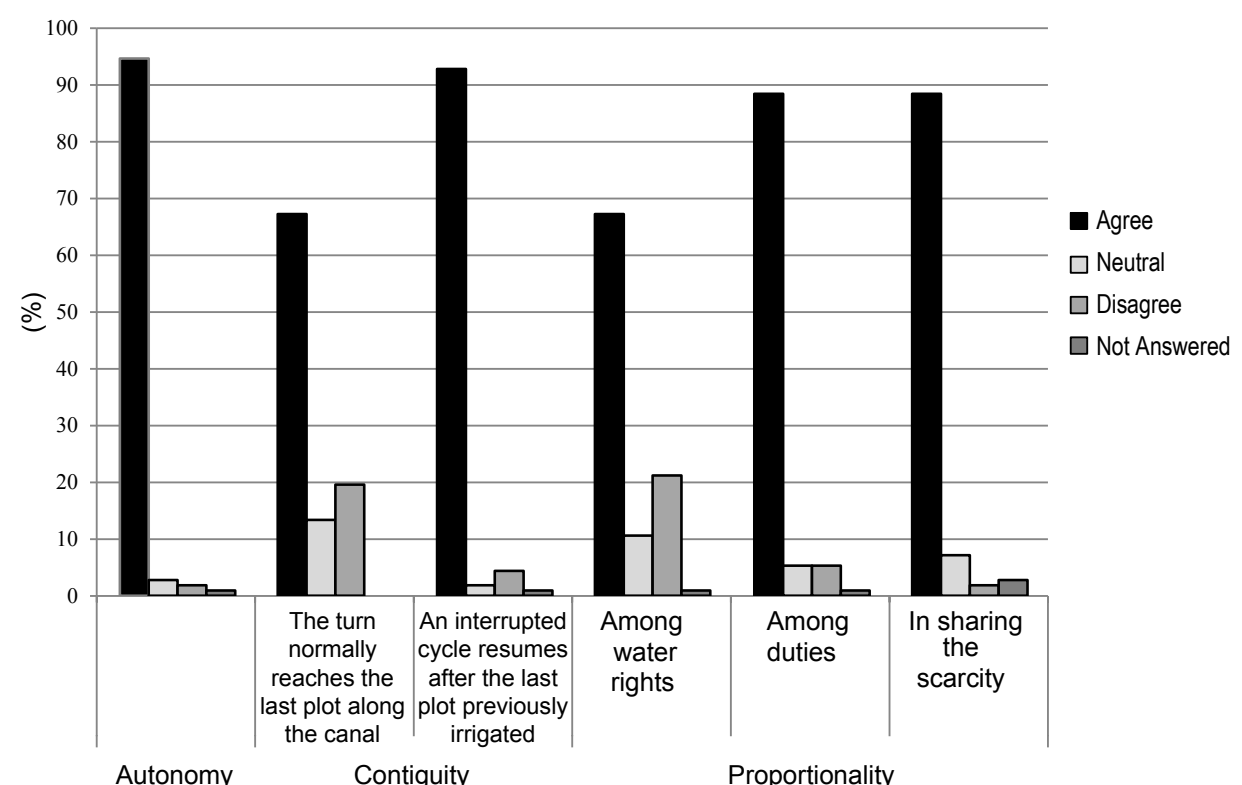

Figure 2.2. Percentages of responses to questions about the operating principles.

people (5\% of the total) pointed to the "tail-ender" WUAs - e.g. Mislata, also certain parts of Rascanya - lying along the far end of a main canal in the lower part of their half of the system. The farmers here actually irrigate continuously, using surplus water draining from the upstream WUAs in order to water their fields at a slow pace, up until the time when the WUAs' formal turns come around in the general cycle. At that point the process speeds up dramatically, with farmers using the entire canal flow to continue until all of the remaining lands have been serviced, at which point the cycle returns again to the upper part of the system.

During the low-water conditions of a typical dry season, the result in any case is a watering frequency that in fact conforms to the rhythm prevailing in the rest of the system. Today this can vary from once per week to a maximum of once every two weeks, depending on the degree of the prevailing scarcity. A few additional people — farmers in every case - expressed uncertainty about this issue, noting that they did not own fields in different parts of the system and thus could not say for sure that the frequency was the same everywhere. Yet everyone agreed that it was supposed to be the same according to some apparently unwritten rule of equity ${ }^{11}$.

11. Nowhere in the WUA's ordenanzas is there a rule stating that the watering frequency must be 
The other $5 \%$ of people who disagreed pointed to the use of the groundwater as creating exceptions. However, further investigation showed that the use of the wells, within the localized areas where the groundwater is extracted and made accessible, does not actually violate the principle of uniformity among rights, as we will see below. The issue is complex, but the groundwater is not generally used as a communal resource in most cases people have to purchase it - and its utilization is not directly governed by, although interestingly enough it is strongly shaped by, the Huerta's traditional communal institutions.

A certain uniformity of watering technique was ultimately acknowledged by everyone interviewed, and this proved to be perhaps the easiest principle to confirm, despite the fact that watering methods in the Huerta actually take two distinct forms. Here it is important to note that, just as in Peru, this relative uniformity is only possible because all fields in the Huerta have been terraced. The local farmers carefully levelled the entire landscape, and have since maintained it annually at substantial labor cost, in order to create this effect and to maximize the absorption of the water. Two different methods are used to accomplish this maximization; however, all farmers agreed that both are employed in a highly standardized way for each crop, a uniformity that had been identified as crucial in the systems studied previously in Peru.

The first method, of building ridges and furrows in the fields to pool the water - features called caballones - is the most widely used and is almost universally employed in growing garden vegetables. Here the width of the raised ridges varies somewhat, being determined by the size of the mature plants, but the furrows or canals between the ridges are excavated to a standard minimum width - one specified in the WUA rules as "dos daus", or about $40 \mathrm{~cm}$.- and to a depth sufficient to hold 10 to $15 \mathrm{~cm}$. of water.

Similar observations apply to the other technique, riego a manta, which involves drawing water in a thin "blanket" (5 to $10 \mathrm{~cm}$. deep) over shallow rectangular pooling structures called tablas, whose surface area is limited by custom. They are formed by low earthen walls located between the scratch canals, and enclose the areas actually cultivated. Although this method can be used to water almost any crop, the technique is mainly used to irrigate oranges and other citrus fruits. Most informants recognized that the two methods, being highly uniform, impose an upper limit in each case on water

the same for all farmers. Moreover, the Huerta as a whole has no written rules. Such uniformity, both within and between the WUAs, is a principle that could only be inferred from the earlier published accounts and then explored in the interviews. 


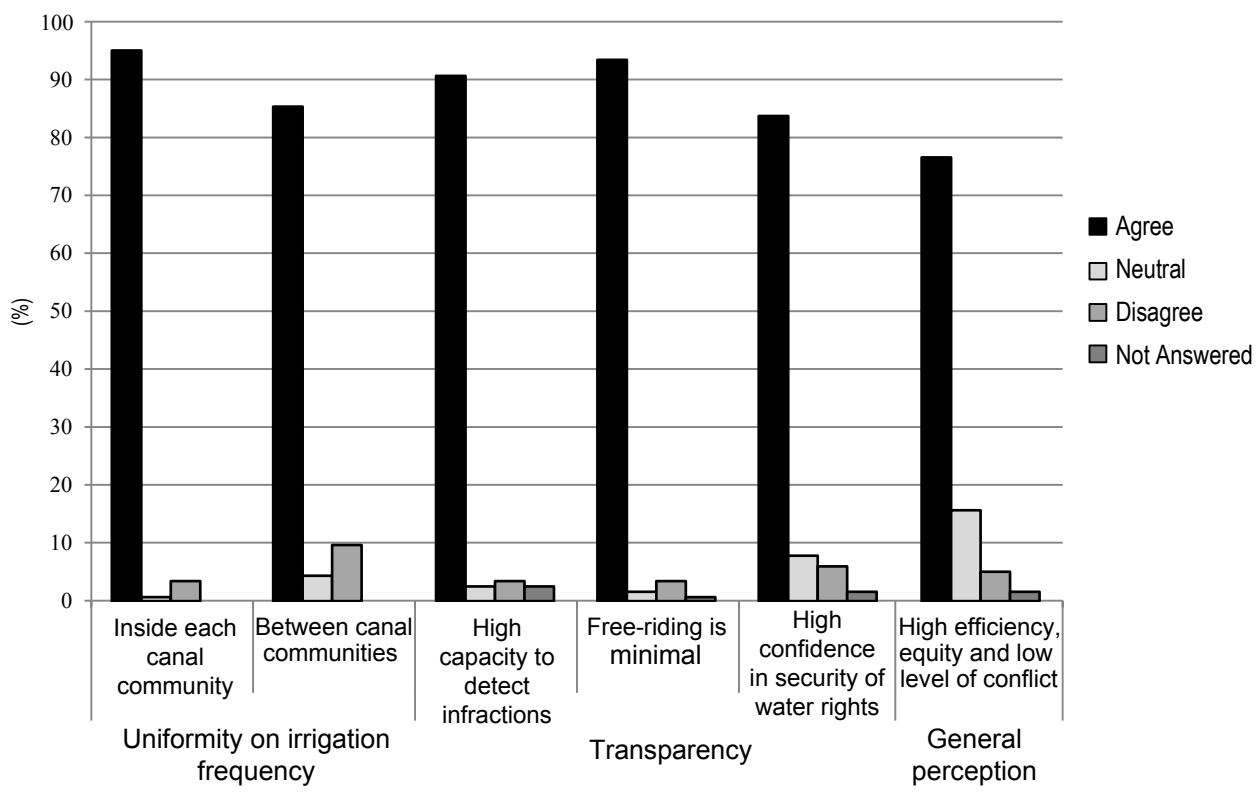

Figure 2.3. Percentages of responses to questions about the operating principles.

consumption and on irrigation time, thus creating the rough proportionality that is seen as basic to water rights in the Huerta.

The principle of proportionality, long cited as the basis of local water allocation (Maass and Anderson, 1978; Ostrom, 2005, 1992, 1990), was immediately recognized by nearly everyone interviewed (see Figure 2.2), but contested somewhat in terms of how well it actually fits local practices. Although most farmers (68\%) agreed that water rights are proportional to the land area irrigated in each case, and therefore to each other, some remained neutral on the issue, expressing ambiguity (11\%), while a significant number disagreed $(21 \%)$. Nearly all of the latter pointed out that, when taking their individual turns, people use as much water as they need to, with the precise amount depending on a number of factors - the specific crop and the watering technique, even the condition of the particular field — and these are ultimately decided by the farmer.

Despite these differences in perception, the use of the river water evidently continues to be seen by the vast majority as equitable and fair, based on its uniform frequency as well as its proportionality to the land area irrigated. People's corresponding duties to contribute to maintenance of the canal system - which in Valencia mainly take the form of a monetary fee paid annually for water use - are also seen as fair because they 
are directly proportional to those rights (affirmed by $88 \%$ of the interviewees). And the fees must be paid if people are to continue to get their water. Thus, as all of the earlier studies indicated - but did not have the opportunity to demonstrate - a pervasive fairness and proportionality are apparently perceived by most people to exist among rights, among duties, and between rights and duties (see Figures 2.2 and 2.3).

Here the only novelty to emerge in the interviews was to confirm emphatically that - as in the Peruvian systems - the most important factor defining equity or fairness in the eyes of local farmers is the uniform frequency, with the amount of water consumed by farmers in each turn being considered far less important. In order for rights to be proportional to each other, and thus to be equitable or fair under conditions of scarcity, the frequency must be the same for everyone. This may seem an obvious point but, as we will see later, it has important implications for how one should view the many other systems in the world where such proportionality - but not uniformity - is reported to exist.

A high degree of transparency was acknowledged by nearly everyone to exist within the system, as shown in Figure 2.3, and most farmers understood that this feature is largely created by the contiguous pattern of water distribution. The principle is vital because it provides farmers with a basic sense of security (affirmed by $84 \%$ of the interviewees) by making it possible for them to assist in enforcing the rules and thereby to protect their own water rights. Significantly, in discussing its importance people generally agreed that transparency is the main reason why the frequency of water theft has always been remarkably low in Valencia. 54\% of the people interviewed estimated that the frequency was either extremely low or virtually nil, while a total of $94 \%$ thought that it was low or better than that. This important issue will be discussed further below.

Two of the remaining principles, boundary maintenance and graduated sanctions, which were first identified by Ostrom $(2005,1992,1990)$ - and which are not shown in Figures 2.2 and 2.3 - were again confirmed by almost everyone in the study, with many people noting that they are crucial in explaining why the local tradition works so well. Note, however, that the system has been expanded - by mutual agreement among the farmers and their representatives - in the recent past, by incorporating the aforementioned extremales in some WUAs. Despite this, people generally gave very high ratings to Valencia's system, as shown in Figure 2.3, in terms of its general effectiveness, as compared to other irrigation systems in Spain with which they were familiar: $43 \%$ 
rated it as optimal, or the best that people can do, while another 34\% rated it as superior to all others in the country. Only 15\% rated it as average, and just $8 \%$ of people felt that it rated worse than that. This reflects great pride in the system, for which the local farmers are well known, but also expresses a high level of confidence in the effectiveness of its institutions, revealing one of the main reasons why people tend so strongly to obey the rules. The final principle, direct feedback on the level of rule conformance, will be discussed below.

The more pessimistic people interviewed, although few in number, placed great emphasis on certain inequities that have emerged recently in the in the use of nontraditional sources of water, to be examined below. This dissatisfaction is significant because it again confirms, by implication, the fundamental moral importance of a uniform frequency of irrigation, while also revealing an emerging and growing threat to the system, one that could ultimately cause cooperation among the farmers to break down.

\subsection{Results: the distribution and use of water during droughts}

The drought that began in 2005 was the worst of the last fifty years, posing a stiff test of the farmers' capacity to adapt through collective action. The failing rains soon caused the water stored in the upstream reservoirs to decline to half its normal level, leading the JDWA to declare a state of drought pre-alert early in 2006 (BOE, 2007; MAGRAMA, 2007). The WUAs of the Huerta, like others throughout the watershed, were required to find ways of reducing consumption accordingly, by $50 \%$, so as to adjust to the slower rate at which water would henceforth be released from the dams.

The Sindics conferred and accomplished this contraction very quickly, by implementing a traditional procedure - again, known as "la dobla"- which was modified slightly to fit the new circumstances. This extended the general watering cycle from its previous duration of one week to a total of two weeks, a frequency that prevailed thereafter throughout most of the Huerta until the drought ended three years later.

The elongation was accomplished mainly by altering the sharing arrangement between WUAs: Moncada and the groups of the inner Huerta simply began to alternate and to use the entire river flow, rather than dividing the flow in half and irrigating at the same time. First, Moncada would use the whole flow for a week; during which not all of its lands would be serviced (see below); then the other WUAs would take over, 
alternating just as they had done before, but now using twice the previous amount of water. The result was a stable two-week cycle covering the majority of the irrigated lands in the Huerta.

The crucial thing to understand about this massive voluntary reduction in the intensity of people's water use - one that is apparently unprecedented in the world literature on irrigation - is that it was accomplished in such a way that, over a large part of the system, all of the operating principles were preserved. This discovery again confirmed our hypothesis, showing that it is the principles underlying the working rules - which themselves are somewhat changeable - that make the Valencia system so robust. However, an additional drought measure was also implemented at the time over roughly half the total area, one that compromised the principles of uniformity and contiguity and greatly complicated the task of monitoring.

A prioritization among crops was introduced by putting one of them - oranges on a much lower frequency, effectively creating a separate cycle for irrigating citrus crops. Note that this rule only took effect in Moncada, which covers slightly more than half of the total land in the Huerta. It is the only WUA where a significant amount of citrus is produced (on approximately $74 \%$ of its land). During the drought, citrus trees were only entitled to be watered every 45 days, which meant that farmers could only irrigate them, along with the other crops, during every fourth turn of the general twoweek cycle. This limit was implemented in Moncada without putting the matter to a vote, apparently being accepted by the farmers for several reasons.

First of all, some further curtailment was necessary in order to achieve the required 50\% reduction, and this change affected the farmers in the WUA fairly equally because most of them do produce some citrus crops. Secondly, orange trees are able to withstand aridity much better than the other crops grown locally; even in the best of times they do not need watering more than once every three weeks or 21 days. Hence the restriction was seen as causing a minimal amount of harm, one that fell rather evenly on most of the farming households. Fourthly, most of the farmers had access to wells upon which they could rely to take up the slack, as we will see below. Finally, the restriction was a traditional one, even though it had not had to be implemented for many years.

When asked about how the restriction was enforced, from a practical point of view, both farmers and water officials explained that monitoring had to be intensified throughout the system, with some also acknowledging that most of this burden now fell 
heavily on the water distributors and less so on the farmers themselves. By all accounts this was a big challenge, but one that the Guardas in Moncada rose to successfully.

The widespread use of the groundwater was crucial in adapting to the drought, but in order to appreciate its role an important point must be understood. Up until passage of the Water Law of 1985, groundwater was legally regarded as a separate resource, essentially an open-access one suitable for private exploitation (Guillet, 2000, 1997). Although the WUAs could have drilled wells for communal use prior to that time, adding the groundwater to the river water and then using the two flows together, only one of the groups, Tormos, assumed the management of a well previously drilled by a group of farmers. Thus the groundwater historically had little to do with the tradition of communal irrigation in the Huerta.

However, in 2006 the JDWA, as part of its drought adaptation plan, drilled one large emergency well for communal use in each of the canal WUAs (MAGRAMA, 2007). That groundwater is now combined with the river water, and both are used conjunctively - with the JDWA's permission - throughout the canal system of each usergroup whenever the conditions require it. Thus its communal distribution and use are, in the case of those particular wells, governed by the same principles as the river water.

The number of 'private' well societies in the Huerta today clearly runs in the hundreds, but our efforts to specify it were unfortunately not successful. At least 75 were confirmed to exist within the nine WUAs of the inner Huerta (Ortega-Reig, 2009), which in each case can be considered overlapping surface and groundwater water user associations. However, two of those user-groups - Mislata and Rovella — do not have any wells, for reasons that are not entirely clear. Several hundred more were reportedly established through time in Moncada, some of which are no longer operating today (Ortega-Reig, 2011).

The JDWA is now in the process of trying to register all of the active ones, a process that is also underway in other parts of Spain. Local water officials appear somewhat reluctant to divulge much information about them, mainly because they fear that a full disclosure will cause their traditional rights to the river water to be reduced. That traditional entitlement, to surface flows that also provide the city with its drinking water supply, is increasingly being challenged today in the local media of the Valencia region, as the amount of river water continues to dwindle.

The groundwater is extracted from the wells at a steady rate by coin-operated 
electric pumps, and fed into the canal networks spanning specific command areas within the Huerta. Although some are used "on demand" much of the time, these largely 'private' wells are only operated when the canals lie empty, i.e. when the river water is not circulating. Irrigators must buy the special-purpose coins, called fichas, from well-society officers, but they do so at two different rates. Founding members of the societies - i.e. people who contributed to the initial well costs - pay a discounted hourly rate, while non-members pay substantially more when making a water purchase, up to twice that amount. However, all landowners within a given well's command area have the right of access; and no one who wants the water and is willing to pay for it can be denied. In this sense, use of the wells conforms to the principle that the frequency of irrigation must be the same for everyone using a given source of water.

Two other arrangements affect the amount of groundwater that can be used each time a person irrigates from a well. In some societies, membership and water access are based only on the possession of land (or in some cases of land-shares) in the well's command area, so that under normal conditions irrigation is on-demand and water purchases are not limited in any way. During droughts, however, such use is restricted by making the frequency of irrigation the same for all fields, and by limiting watering time per hectare to a single ratio or proportional amount. In this sense, the use of the groundwater - again, a fairly recent development — has been strongly shaped by the Huerta's long tradition of communal water use.

In other societies, access to the well water is based on the initial buying, by farmers, of individual time-shares, which did not necessarily have to be proportional to the land area irrigated, although one suspects that they probably were in most cases. Here, however, water purchases are limited to a uniform number of hours per share, under both normal and drought conditions. During droughts, however, a further restriction is imposed, namely alternation or turn-taking: a farmer cannot buy or use more coins to start the next round until everyone who wishes to irrigate in a given cycle has taken their turn (Ortega-Reig, 2009, p. 39). The watering frequency under emergency conditions is thus the same for everyone, again revealing a strong shaping effect.

It is important to point out that, despite the fairly liberal and uniform rules of access to the wells, significant portions of the total areas served by some of the Huerta WUAs remain excluded, being out of reach of any of the 'private' water: e.g., approximately $60 \%$ of Quart, $52 \%$ of Mestalla, and from 3\% to $10 \%$ of Xirivella, Rascanya, and 
Favarra. Moreover, two of the canal WUAs have no private wells at all, continuing to rely almost entirely on the use of the river water and an additional emergency well. This disadvantage becomes doubly great once one takes into account the fact that the other canal WUAs - those that have wells - have the option of purchasing well water in bulk from the well societies, for communal or collective use when they need it. Several WUAs did this repeatedly during the recent drought, spending a lot of money — funds pooled together by the farmers - in order to deal with the three-year emergency.

The interviews showed that the well water is routinely used during years of normal rainfall in order to prevent delays in situations where the precise timing of irrigation is critical, such as during crop planting. The more regular use during droughts is far more important, but this is done specifically in order to supplement, or effectively to shorten, the general cycle of surface-water use. The farmers strongly prefer the water of the Turia River, due to its very low cost and relatively good quality. Thus the more expensive - and slightly saline - groundwater was used during the drought to irrigate a second time, in the week immediately following the twice-monthly cycle of surfacewater use (which itself took one week), in order to limit the total time that passed between waterings to one week rather than two, specifically to benefit commercial crops (excepting oranges) (Andreu et al., 2010).

Most farmers did this, despite the substantial increase in their production costs, in order to maintain the high quality standards that are imposed today by the supermarkets, both domestic and foreign, especially in the production of melons, onions, and garden vegetables. In Moncada, many of the orange producers also relied heavily on purchased water during the drought. They used the groundwater, again as a supplement but in a less regular manner, in order to make certain that no more than 20 to 30 days passed between irrigations, a limit that otherwise could not have been maintained.

The significance of this advantage should again be emphasized, as should the resulting inequity, not among people's water rights but in their actual access to the resource. Many of the excluded farmers feel that both kinds of water should be communally owned, and that the two flows should be combined and used together for the benefit of everyone, as is the case with the emergency wells. Such criticism was either expressed directly or implied in the remarks of most of the farmers who felt that the Valencia tradition, while equitable and highly successful in comparison to most others, 
is still far from perfect.

One of the most important things we were able to confirm was that, despite the much higher frequency of groundwater purchases during droughts, the rate of water theft remained amazingly low, even though it was higher than during the years of 'normal' rainfall. Glick (1970, pp. 54-59) and Ostrom (1990, pp. 74-75) were the first scholars of Valencia to explore this matter, using remarkable records of the 15th-century from nearby Castellón - a highly similar but much smaller Huerta - to argue that the rate of theft in Valencia during medieval times was probably similarly low. The two authors were able to calculate that the Castellón farmers were fined for rule violations at a rate of only $.008 \%$ per year, with an average of 200 fines issued each year during a period when the farmers together irrigated more than 25,000 times annually, which of course were opportunities to steal water. This rate, however, did amount to more than one fine per day, indicating that a high level of vigilance prevailed at that time throughout the system.

This argument based on extrapolation through both space and time was bolstered recently by Favrettto (2004), who was able to gain access to the written records of Valencia's Water Tribunal and to count the number of denuncias, or formal accusations of rule violations, that were sustained and punished by the court each year during the period from 1945 to 2002 . Her analysis documents a notable decline throughout the entire period in the rate of infractions of all kinds, but particularly in those for water theft. Interestingly, beginning in the 1980's there was a conspicuous drop in reports of infractions that she categorizes as 'traditional' - e.g., those attributable to people's efforts to get more water, or to their tendency to waste it or take it out-of-turn - and a marked increase in violations associated with, or attributable to, the ongoing process of urbanization, such as building in the canal right-of-way, or throwing contaminated water and refuse into the canals.

Favretto's data can be used to calculate the extremely low rate of accusations of water theft that prevailed in the inner Huerta during the latter half of the 20th century. Throughout the 57-year period, the thousands of farmers there would have had more than 90,000 opportunities to steal water each year, during at least 24 turns of a two-week watering cycle (or 48 turns of a one-week cycle). Yet the number of fines issued each year for theft varied from only 1 to as many as 49, with a mean of 15.6 and a large standard deviation of 16.0. The rate of reported theft during the entire period 
was therefore $.0002 \%$ per year, which amounted to an average of only 2 cases reported during every million acts of irrigation. This translates into less than one reported theft for every round of the irrigation cycle for the inner Huerta, which involved more than 10,000 farmers.

The pattern was equally impressive during this time in the other half of the irrigation system, in Moncada. We were able to gain access to the records of its Water Tribunal for the 12-year period from 1999 to 2011, which included both normal and drought years (Ortega-Reig, 2011, p. 75). During the years of normal rainfall (2001, 2002, 2003, 2004, 2009, and 2010), the rate of reported theft was .000003\% per year, with only 8 complaints adjudicated during the entire 6-year period. During the years considered ones of drought, including the recent emergency (1999, 2000, 2005, 2006, $2007,2008)$, the rate was nearly four times as high, or $.00001 \%$ per year. Yet this amounted to only 16 cases reported during that entire time, among more than 9800 irrigating farmers. As Ostrom (1990, p. 74) basically predicted in her analysis, the rate is generally astonishingly low, but it remains sensitive to the prevailing conditions; it could be doubled, tripled, or even quadrupled and yet still indicate a remarkable degree of conformance with the rules. To call Valencia's tradition successful and robust is therefore to understate greatly the hydrological and social reality. The degree of social order and cooperation sustained in Valencia throughout the years and even the centuries, in situations of prevailing scarcity, may well be unrivalled anywhere else on the planet.

\subsection{Discussion: the hypothesis of convergent evolution}

The striking parallels among the institutions existing today in Valencia and those in the previously-studied systems in Peru are evidently the result of convergent social evolution: the emergence, among unrelated and distinct societies, of highly similar adaptations to similar environmental conditions, in these cases to general aridity and to drought. It is extremely unlikely that traditional practices in Valencia somehow diffused to the communities in the Andes where the operating principles were first identified. All of those communities are small indigenous villages, located in high-mountain valleys noted for their geographic remoteness (Trawick, 2001a, 2001b; Treacy, 1994a, 1994b).

The possibility does have to be considered, since farmers from Spain's Mediterranean coast are known to have migrated to other parts of the New World quite early in the colonial period. Spanish colonists, probably originating from the area 
around the city of Granada, established themselves at that time in northern Mexico and in what would eventually become New Mexico in the U.S., bringing with them practices and techniques of Islamic origin and building entirely new irrigation systems, ones apparently modelled on Valencia's. In some of these acequia systems a highly similar "canal culture" persists to this day (Brown and Rivera, 2000; Cox and Ross, 2011; Rivera, 1998).

There is no evidence that this happened in Peru, however. There, the villages and irrigation systems - including those previously studied (Trawick, 2003a, 2003b, 1994; Treacy, 1994a, 1994b) — are known to have predated the arrival of the Spanish by hundreds of years, having been built by the Incas and their predecessors. Independent emergence is a far more plausible explanation, a phenomenon that probably occurred for one simple reason: the principles of operation are simple and yet work extremely well. Indeed, when found together as a set, we feel that they form a kind of optimal social configuration, a model for coping effectively with scarcity and with drought, at least for a certain type of farmer.

The possibility of a direct evolutionary link arising from the colonial system of governance has been discussed elsewhere, and there is no need to review that argument fully here (Trawick, 2001a). In her analysis of Valencia, Ostrom (1990, p. 81) observes that the policies and practices imposed by the Spanish Crown in governing the New World generally originated in Castile, in central and western Spain, at a time when the municipalities of the Mediterranean coast - those belonging to the eastern kingdom of Aragón, such as Valencia - were largely autonomous, especially in irrigation, a freedom they had been enjoying for centuries. She notes that colonial governance policies were generally "modelled on Castile" rather than Aragon, and the evidence on early water law in Peru strongly bears this out.

In ethnohistorical research done on Cuzco, the former Inca capital, during the 17th-century, Villanueva and Sherbondy (1979, p. xvii) have shown that the colonial Spaniards, who partly reorganized local irrigation in Peru at that time, imposed foreign practices only on the lands that they directly owned and controlled — the haciendas while they "...respected the ancient water regime of the lands of the indigenas and left the distribution of water in their hands, according to ancient usage". That policy was still faithfully followed more than two centuries later in the provisions of Peru's Water Law of 1902 (Pasapera, 1902), which was closely modelled on the earlier Spanish Water 
Law (Trawick, 2003a, pp. 159-160). Both laws stipulated that water utilization in the indigenous communities was to continue undisrupted, and to follow traditional 'uses and customs'. The colonial policy was a dual one based on the feudal pattern of allowing private ownership of water on hacienda lands - thus mirroring traditional practices in Castile rather than Aragon — while not interfering with indigenous practices in any way ${ }^{12}$.

In considering the convergence hypothesis, it is important to note that the specific rules from which the operating principles are derived, although similar today in the various systems in question, are not identical. For example, the order of water distribution and use in the Peruvian communities, while fixed and contiguous, appears to be bottom-up in every case rather than top-down as in Valencia. Such a reversal is hardly the kind of change one would expect to be imposed by the rulers of a rigid and feudal colonial society, especially if those people came from Valencia.

Furthermore, the terminology of local practices in the two cases - although exhibiting the kind of overlap one would expect to see today in Peru, when nearly all people in the highlands are bilingual and fluent in Spanish - is linguistically distinct. In the Peruvian communities, the local terms denoting key elements of the distinctive kind of irrigation system being described here - from diversion dams (yutas), tanks (qochas) and canals (yarqhas) to turn-taking (mitay), equitable water shares (rakis), and standard water-containment features (atus) — are in Quechua, the Inca language (Trawick, 2003a, 2003b, 2001a, 2001b; Treacy, 1994a, 1994b). Today those terms coexist with, but probably pre-date, their Spanish counterparts, which admittedly are also used. But one does not see this kind of dual terminology in parts of North America that were colonized by people originating from the Valencia region. There the only terms used are Spanish (Rivera, 1998, pp. 227-232), obviously because the local irrigation traditions were established by Spanish people rather than by indigenous ones, as in Peru.

Finally, and most importantly, there is the fact that highly similar communitymanaged irrigation systems - ones likely to conform to the same model — clearly exist in many other parts of the world. There too farmers appear to have converged on the same set of principles in learning to cope with scarcity. The various comparative analyses of successful systems that have been done to date all cite proportionality among rights

12. See Trawick's discussion (2001a, p. 363) of Garcilazo's well-known ethnohistorial account of how irrigation was supposedly carried out in the provinces under the Incas, one that mentions most of the principles discussed here and is entirely consistent with the moral economy model. 
and duties (Coward, 1979; Maass and Anderson, 1978; Ostrom and Gardner, 1993; Siy, 1982; Wade, 1986), or among benefits and costs (Agrawal, 2002; Baland and Platteau, 1996; Ostrom, 2005, 1992, 1990; Tang, 1992) as the central organizing principle. In so doing, they point to an important commonality in the way that the central value of equity, or fairness, is defined in a great many local irrigation societies throughout the world. It can be said to arise from the fact that in nearly all of them water is seen as directly, and inseparably, tied to the land.

If it is true, however, that water rights cannot be proportional to each other unless the irrigation frequency is the same for everyone - as the farmers in both Valencia and in the Peruvian systems seem to insist - and unless watering techniques are also fairly uniform, then such uniformity is highly likely to exist in most or all of those previouslystudied systems. As was the case in Valencia, the principle may have been overlooked, or perhaps been implicitly assumed to exist, in the earlier published accounts. In either event, its full significance was clearly not understood.

If such uniformity is indeed present, then most of the successful systems documented to date in the world literature must conform to a single model. Based on that likelihood, we assert that this type of equitable, transparent, and robust irrigation system - which we call the "moral economy of water" (Trawick, 2010, 2008, 2001a, 2001b) - has emerged repeatedly, and often independently, in many different parts of the globe, wherever small farmers have learned to cooperate in coping successfully with a persistent scarcity. It appears to exist in hundreds of locally-governed canal systems, of various scales and degrees of social complexity, in Peru (Treacy, 1994a, 1994b), Spain, Mexico (Palerm-Viqueira and Martínez-Saldaña, 2000), New Mexico (Cox and Ross, 2011; Rivera, 1998), India (Wade, 1987, 1986), Nepal (Lam, 1998; Ostrom and Gardner, 1993; Shivakoti and Ostrom, 2002), Bali (Lansing, 1987, 2006, 1991), and the Philippines (Coward, 1979; Siy, 1982), as well as in many Islamic countries.

The principles do work extremely well, which must explain why they have repeatedly been invented or discovered and then adopted so widely in coping with scarcity. This ethnological point can now be appreciated from both the emic, or culturespecific perspective of the local farmers, and also from a more etic, or scientific and pan-cultural, point of view. When found together as a set that underlies local practices, the principles interact in a unique way, forming a kind of integrated whole or model, a configuration whose combined effect is to strongly reinforce people's motivation to obey 
the agreed-upon rules.

Note that this incentive is basically a positive one, rather than a merely negative one resting on the near certainty that any violators of the rules will be detected and punished. And here the uniform frequency of irrigation, that most basic commonality and equality among people's water rights, is the key, as the vast majority of our interviews in both Spain and Peru have confirmed.

The arrangement is of course fair, and for that reason uniformity should perhaps be seen as inherent in, or as logically implied by, the principle of proportionality. But it is crucial for practical reasons as well as moral ones. Such uniformity has the effect of creating a direct and obvious link, to the individual farmer, between the 'efficiency' and orderliness of water use and the duration of the irrigation cycle, one that cannot be created through any other kind of institutional arrangement.

When everyone waters their land in a single rotation, and when any expansion of the overall system is prohibited, the water saved by people through frugality and selfrestraint causes the distribution cycle - the great circle turning at the heart of things - to run faster. This is in part because it minimizes the total surface area of canals in use at each moment in time, this reducing evaporation and filtration. By limiting watering to the shortest acceptable period and by obeying the rules, people are thus able - quite visibly and obviously - to irrigate more often, as often as possible throughout the year and from a long-term point of view. This benefit was captured beautifully in one Valencia farmer's account of irrigation during the dry season of a normal year:

"...we endeavor to be there at the edge of the field waiting for the water when it arrives, standing as next in line, so that we finish quickly and in that way the water arrives at Puçol and then returns. [With] this 'water wheel' that we make, we are irrigating every eight days, and we don't spend money on the wells." (Ortega-Reig, 2011, p. 67).

This image of a noria or water wheel is a striking metaphor for the kind of maximizing and yet self-restrained and cooperative behavior that clearly predominates throughout the Valencia system. People standardize and limit their own water consumption in the short term in order to maximize its availability for themselves and everyone else in the long term. Such behavior is mostly inwardly focused within each local user group, in response to what is widely perceived to be a basic compatibility, even a congruity, between individual self-interest and the common good, two social constructs that are often defined in purely abstract terms and assumed to be opposed. 
In an irrigation system of this kind, the peculiar characteristics of water make it possible, not just to mediate, but to transcend this most basic of all conceptual oppositions. Most of the people interviewed in Valencia, like many of those involved in the earlier studies in Peru, seem to see the two concepts as entirely compatible in irrigation, provided that the watering frequency is the same for everyone. In this regard, the farmer's reference to eight days in the above quote is extremely significant, and drives home the point being made.

Today the river water circulates in Valencia during the seasonal low water of a 'normal' year for one week, while during a drought year the duration is two weeks; this refers to how long the main canal gates remain open in each WUA. But there is an additional delay of one day that passes between irrigations for each person in each of those cycles, due to the fact that the water, once released, is somewhat slower to circulate and to be used throughout the canal system. In our interviews, farmers invariably referred to people irrigating every 8 days or every 15 days, and, unless they were Sindics or Guardas, they never described cycles as lasting one week or two, nor did we ever hear reference to 7 days or 14 days passing between waterings, a discrepancy that was puzzling to us at first.

The reason has since become clear: the length of the formal distribution cycles and the number of days that pass between waterings are two different things. In explaining how the system works, farmers invariably focus on the latter — unlike the water officials - because that number is far more important from a social point of view, being the most basic thing that the farmers have in common. The discrepancy, it should be noted, cannot be inferred logically from the written ordenanzas; its existence can only be discovered through interviews and then ultimately confirmed through observation.

In an irrigation system of this kind, free-riders - people who ignore the rules and sometimes succumb to the temptation to steal water or to waste it - interfere with the efforts of others to shorten the watering cycle and instead cause it to lengthen and slow down. The arrangement generates strong social pressures against such behavior, pressures that, in a highly transparent system, are ultimately effective in controlling a category of persons who are highly stigmatized in Valencia, just as they are in Peru: “espavilats" [exceedingly bold or brazen individuals] "parásitos" [parasites]; "ratas" [rats], “listos” [literally 'sharp ones'], and “personajes “ [characters or 'important' persons] are terms that were consistently used in referring to such individuals. And, as more than one 
farmer in Moncada observed,“...they are always the same characters, and all of us know who they are." (Ortega-Reig, 2011, p. 68).

The central adaptive feature - a strong incentive to be both efficient and vigilant so as to maximize the frequency of irrigation for one's self and for everyone else - is clearly evident in the use of surface water in Valencia, as we have seen. It makes possible the integrated use of the two kinds of water in successfully adapting to drought, a process that, on the basis of the river water alone, has been going on in the Huerta for centuries. The set of institutions which creates that basic and successful adaptation can now be fully appreciated, one that must also exist in a great many other systems throughout the world, 'peasant' or smallholder systems in every case.

Note that the entire Valencia tradition rests on this equitable and robust foundation. The customary and regular use of the river water makes possible the parallel but more periodic and limited use of groundwater, specifically in order to meet the high crop-quality standards that competing in the global 'marketplace' nowadays imposes, a competitive social pressure that comes into the foreground most forcefully during droughts. This pattern of syncopated and supplementary groundwater use, built on a foundation of equitable but adjustable surface-water use, parallels a similar arrangement found in some of the previously studied communities in the Andes (Trawick, 2003a, $2003 \mathrm{~b}, 1994)$. Thus it is not entirely unique to Valencia. The arrangement is, however - despite its current inequities - notably more 'efficient' and sustainable than the practices prevailing today in most other parts of the world.

Before concluding, it is important to point out that, with the one notable exception of the Water Tribunal, the hydraulic tradition in Valencia is predominantly secular and lacks any element of ritual. The contrast could hardly be greater with the previously studied systems in Peru, where farmers clean the main canals together each year through communal and highly festive group labor, after making burnt offerings and drinking to the mountain deities (Gelles, 2000; Trawick, 2003a, 2003b, 1994; Treacy, 1994a, 1994b).

In Valencia there are no priests and water temples, such those of the famous subaks of Bali (Lansing, 1987, 2006, 1991), just a weekly public court that is a rather sombre affair, witnessed silently by hundreds of onlookers. Yet even in the case of Bali the similarities with the Water Court are obvious; and important matters are, in both cases, ultimately decided democratically by the farmers, with or without the blessing 
and the guidance of the goddesses and gods.

It is possible that a stronger ritual dimension once existed but has gradually been lost in Valencia, which, like other cities in Spain, is widely known for its vibrant annual saint's day fiesta. In any case, the largely secular nature of the local tradition shows that big group celebrations, as exciting and expressive of comunitas as they are, are not necessary in order to maintain order in irrigation and to renew a strong ethos of cooperation. A number of factors appear to interact in Valencia to sustain that communal spirit, all of them necessary but probably not sufficient conditions that encourage success, both here and in other parts of the world: a high degree of cultural homogeneity, a limited range of stratification among households, and small farms with similar but not identical water needs.

Ultimately, however, the authority of the elected leaders and the hired water guards, like the quasi-sacred character of the rules themselves - both written and unwritten - are vested in the fact that they are outcomes of collective choice and collective action. Above all, they are effective and they work, maintaining an equity and transparency almost as reliable as the circular motion of a noria, a water wheel.

\subsection{Conclusion}

In concluding, it is worth considering some of the reasons why the widespread existence of this kind of successful local irrigation society has not previously been recognized. The argument for convergent evolution has been made before, though only briefly, in discussions of the Peruvian data (Trawick, 2001a, 2001b) and in preliminary overviews of the research that was then ongoing in Spain (Trawick, 2010, 2008). Those presentations relied mainly on reading between the lines of the existing literature, arguing that uniformity had to exist wherever proportionality did, in Valencia and more widely throughout the world. That initial argument drew little response, but the ensuing silence and apparent scepticism of readers seemed to rest on two critical foundations.

One set of readers, exemplified by Boelens and his research group (Boelens and Dávila, 1998; Boelens and Hoogendam, 2002; Roth et al., 2005), has consistently taken the position that equity in irrigation means different things to different people, that fairness is defined and achieved in very diverse ways in various settings throughout the world. There is said to be no significant commonality among those local definitions, and little to be learned from looking at them comparatively and ethnologically, as we 
have done here.

This research group, which has done remarkable work on irrigation development in many locales in Latin America, has thankfully been one of the most prominent defenders of the water rights of indigenous people and peasant farmers, in the Andes and elsewhere. Those rights are under threat today, by mining companies, chemical companies, and agribusinesses (Bebbington, 2009), all driven by the same relentless processes of expanding consumption and rapid urban growth that threaten the rights of the farmers in Valencia.

Their defence, however, has been couched in a language (Boelens, 2008) expressing opposition to all forms of conceptual abstraction, hostility to analytical models, even an antipathy towards generalization itself. The clear implication is that such abstract thinking is always aimed at the "normalization" or standardization of local practice, and is therefore ethnocentric, neo-colonialist and hegemonic, peculiar to the dominant Western tradition and the capitalist way of life, and certainly alien to the thought of indigenous people. This is simply not true, as our research in both Peru and in Spain has shown. We feel that the interests of indigenous people and peasant farmers have not been adequately served by adherence to this post-modernist and post-structuralist position, however fashionable it may have been during the last three decades.

To defend "difference" as somehow inherently valuable, no matter what forms it takes, is clearly problematic, in irrigation or in any other domain of social life, especially when underlying similarities or commonalities in practice are ignored. And the position has certainly been counterproductive in an era when competition over tightening water supplies is demanding, quite inevitably, that peoples' use of the resource be shown empirically to be 'efficient'.

A second set of readers, exemplified by Mosse (2006a, 2006b, 2003), has, in a similar way, expressed great scepticism that any set of rules or principles exists which can lead, in a predictable way, to desired social outcomes. The many variables of social history and physical setting are said to be so complex and specific in irrigation that they will ultimately defeat people's intentional efforts to adapt to them. It is therefore questionable that such a thing as a successful or robust irrigation system even exists; and we can certainly never predict what the outcome of a particular local effort to create one will be. 
Importantly, it is Mosse who has shown, based on an analysis of several cases in India, that the rules supposedly governing communal irrigation systems often turn out to be idealized representations bearing little resemblance to social reality. Indeed, his firm scepticism has been one of the main forces driving us forward in this research, in an effort to provide the kind of documentation - grounded in interviews if not always in comprehensive ethnography - that would allow a rebuttal. And we believe that we have finally done that here.

As Mosse demonstrates quite clearly, the Indian systems he analyzes so closely - which appear to conform to the moral economy model in theory but not in practice were never 'bottom-up' or self-organized and self-governing systems, either in their construction or in their operation, until the very recent devolution of governance responsibility to local farmers under a program of national irrigation reform. Thus it is hardly surprising that, in local village societies based on ancient and rigid divisions of caste, the outcome today is widely as he describes, featuring marked discrepancies in the frequency with which people actually get their water. The cases do demonstrate that no set of rules - even the simple and elegant set that we have defined here - is selfenforcing, but surely that is something we already knew.

If the "moral economy of water" does exist in all of these parts of the world, in so many different local settings, then clearly it is of great theoretical and practical significance. The evidence would now appear to be abundant, and convincing, that this kind of irrigation system can be built intentionally around an explicit set of rules, in a way that does produce somewhat predictable outcomes. The resulting systems are often equitable, transparent, and robust, as well as being both socially and environmentally sustainable. And they are based on a distinctive, and eminently social, idea: that irrigation is about sharing a scarcity of water fairly among fields and households, not about providing optimal amounts of water to crops.

The underlying principles strongly promote efficiency in water use, as we have seen, in order to minimize the prevailing scarcity. But that benefit remains firmly tied to the land, so that it can be enjoyed by all fields, all landowners, and all crops, equitably and in proportional amounts, as Maass and Anderson first recognized. The uniformity principle is, however, the key to why the system often works so well. And it, in turn, is based on an assumption of scarcity, the idea that in irrigation - as in so many other domains of social life - there is often far less than enough to go around. Under this kind 
of regime, decisions about the crops are left up to the farmers and their families, and the system is in no way designed with crop requirements in mind.

That being the case, the moral economy type of system departs fundamentally from, and even opposes, the agronomic and technocratic model that guided government water policy throughout most of the world during the 20th century, a model that also underlies recent neo-liberal proposals for worldwide water reform (World Bank, 2004). Therein lies its real contribution: the challenge that it poses, based on the traditional practices of indigenous people and peasants all over the world, to business-as-usual in irrigation, and even to nearly all forms of national water law (e.g., Peru's 1969 law, or the current law of Ecuador, as well as Peru's 2009 reform law).

The conventional model, which provides the foundation of most of those laws and remains hegemonic today in most countries, is based on the idea that irrigation is about meeting the water 'needs' of crops, providing plants with optimal amounts through procedures too complex for local people themselves, without technical assistance, to oversee. It in turn rests on the assumption that enough water is available to do this, an idea that, in many parts of the world, has outlived any usefulness it may once have had as a basic approach. Because of it, irrigation under scarcity has long been seen as a special case or an intermittent challenge, rather than as being the normal state-of-affairs.

Provided that surface water is used sparingly and equitably during its yearly fluctuations, in the manner we have described here, there may be, under some circumstances - perhaps even in a great many local cases - enough groundwater available to supplement routine irrigation and to meet the 'needs' of the most important crops. In such situations it may be possible to optimize water allocation for commercial crop production, as in Valencia, by using groundwater regularly as a supplement and then employing it especially intensively during droughts. But the agronomic model is ultimately neither adaptive nor sustainable as a basic approach, one standing on its own, in a context of growing scarcity being induced by population growth and climate change. We feel that the management of water resources in many parts of the world will not prove to be successful in the long run unless it is rebuilt on a moral economy foundation.

Some authors (Bakker, 2011, 2007; Bolding et al., 1995; Mollinga et al., 2007), in pointing to the limitations of community-based irrigation - and of participatory approaches to resource management more generally - have cited the literature on farmer- 
managed systems, specifically those where (as in India) operation and maintenance have recently been taken out of the hands of government bureaucracies and turned over to local irrigator groups. This "Big Bang" devolution of management responsibility was carried out, primarily in large-scale canal systems of surface-water use, in many countries beginning in the 1970's: e.g. in India (Bharadwaj, 1990; Narain, 2003; Sengupta, 1991), the Philippines (Korten, 1982; Siy, 1989), Mexico (OECD, 2013), and even in Peru (Trawick, 2003b). And the results proved to be mixed, exhibiting in many cases failures in which the uncontrolled local use of groundwater is now a serious problem.

Several authors, most significantly Ostrom (2007), have rightly noted that this massive experiment showed that community-based management is not a panacea, any more than water markets are, or state bureaucratic control, an assertion with which we heartily agree. They argue that we should therefore abandon the search for simple solutions based on primary reliance on a single approach to management.

Yet, throughout all of these national attempts at reform through devolution, the agronomic model for irrigation has remained dominant, guiding most local efforts to change the way things were done. The idea that different crops require different amounts of water - and that they should get it, on different schedules and cycles - has reigned supreme as the basic approach (Bharadwaj, 1990; Narain, 2003, pp. 26-30; Sengupta, 1991). Unfortunately, in the hands of small farmers and peasants, who often grow the same array of crops and whose water needs are therefore fairly uniform, it is a recipe for chaos and conflict, at least when water is scarce. Systems based on this approach are invariably opaque, rather than transparent ${ }^{13}$; and people lack any strong incentive to conserve the resource because they irrigate at several different frequencies on different cycles in an order that is, above all, flexible and changeable. The crucial link that can provide farmers with an incentive to be 'efficient', the link between the conditions of individual water use and the duration of the watering cycle, does not exist. Unfortunately, the farmers in the large-scale government-built systems that have recently been reformed, apparently lacking any management tradition of their own peasant farmers in nearly all cases - were given no other model to guide them ${ }^{14}$.

13. See Trawick (2003a), Chapter 7 for a well-documented example in Peru.

14. The famous warabandi systems of Pakistan and India, the largest in the world, were of course strongly promoted by the World Bank for more than a decade as both a model and a test case for decentralization and for participatory irrigation management (Khan, 1984, pp. 26-30; Malhotra, 1982; Singh, 1984). The problem with this plan, and the main reason for its disappointing 
How different might the results have been, had these reforms been guided by a different model, a more traditional one based on more realistic assumptions? Perhaps someday we will have the opportunity to find out. The evidence now available suggests that the jury may still be out on these massive efforts to bring about much-needed change. But it is no longer out on the merits, or at least the potentials, of communitymanaged irrigation, on the capacity of small farmers to successfully manage their own water, in a world characterized increasingly by fluctuation and scarcity.

results, is that in the warabandis there is no link, in the eyes of the farmers, between the 'efficiency' of their water use and the duration of the irrigation cycle. The frequency and duration of people's turns are both fixed but the amount of water available to them each time is not, so that under scarcity farmers are unable to irrigate all of their fields and often all of their crops in each turn. One turn is thus not necessarily equivalent to another, and more than one is often necessary to irrigate all of a person's land. Thus, by using water more frugally, farmers are not therefore able to irrigate more often, a form of negative feedback and maximization of benefit that is crucial to the success of the moral economy type of system. The warabandis are so enormous, consisting of 50,000-hectare blocks of land, that this crucial link does not and apparently cannot exist. Furthermore, they were not initially bottom-up organizations, either in their construction or their operation, having been built in the late 19th and early 20th centuries by the colonial British. 



\title{
The Integrated Use of Surface, Ground and Recycled Wastewater in Adapting to Drought in the Traditional Irrigation 3. System of Valencia
}

\author{
Ortega-Reig, Palau-Salvador, Cascant i Sempere, \\ Benitez-Buelga, Badiella and Trawick (2014), \\ Agricultural Water Management, 133, pp. 55-64. ${ }^{15}$
}

\subsection{Introduction}

As climate change continues and water supplies in many regions of the world grow increasingly scarce, scholars in several fields are showing great interest in the study of irrigation. On a theoretical level, discussion among irrigation specialists often focuses on adaptation - the means farmers employ of coping with less water in adapting to major fluctuations in the supply_-particularly on revealing the ways in which farmers modify their use of diverse kinds of water resources. A consensus seems to have emerged that agricultural water use in the 21 st century should be both "integrated" and "adaptive" in these respects (Pahl-Wostl et al., 2007). An integrated management should include the use of the resource in a broad perspective (e.g. water for irrigation, preservation of groundwater, flood risk and integrity of ecosystems). In addition, adaptation refers to changes in the processes or structural elements of the governance of water resources as a response to changes in societies or the natural environment (Pahl-Wostl, 2009, 2007a, 2007b).

However, very few concrete examples of such sophisticated practices appear to exist. This paper focuses on one case-the irrigation system belonging to farmers of the famous Huerta of Valencia in Eastern Spain-where the use of water involves the integrated use of multiple sources, and where traditional use is being modified in order to cope with droughts that appear to be caused by human-induced climate change.

15.@(1) $(2014$, Ortega-Reig, Palau-Salvador, Cascant i Sempere, Benitez-Buelga, Badiella and Trawick. Licensed under the Creative Commons CC-BY-NC-ND 4.0 license. The definitive peer-reviewed and edited version of this article is published in Agricultural Water Management, 133, pp. 55-64, 2014, doi: 10.1016/j.agwat.2013.11.004. 
Valencia is one of the best-known examples in the vast literature that now exists on successful farmer-managed irrigation systems in different parts of the world. Maass and Anderson (1978) describe the operating rules in Valencia. Sales-Martínez (1988) studies how the traditional Valencia system has, over the past few decades, included land that formerly had no rights. And Ostrom (1990), based on Maass and Anderson (1978), has drawn attention to the conditions under which farmers groups manage water successfully. In addition Garrido $(2012,2011)$ has reviewed, based on historical data, the evidence used in the work of Ostrom (1990) for the study of irrigation institutions in eastern Spain.

Several studies of irrigation focus on operating principles through field empirical case studies (Lam, 1998; Mabry and Cleaveland, 1996; Ostrom, 2002, 1992, 1990; Tang, 1992) also on ethnographic research (Coward, 1979, 1976; Hunt, 1989; Hunt and Hunt, 1976; Trawick, 2008, 2001b; Wade, 1987). Moreover, Boelens and Hoogendam (2002) pay further attention to how individual and collective rights are created in peasant farming systems, and other authors have reviewed the relation between inequality, heterogeneity and cooperative behaviour in irrigation systems (Bardhan, 2000; Bardhan and Dayton-Johnson, 2002). Regarding multi-source management the case of Tehuacan valley shows a case were cooperation between individuals and organizations took place to manage multiple water sources (Palerm-Viqueira and Martínez-Saldaña, 2000).

In the studied case of Valencia, nine WUAs define a unique irrigation system with around 4,100 ha because they act conjointly in decisions concerning deriving water and water sharing. In addition, channels and derivations of upstream and downstream WUAs are connected. This complex system contrasts with the smaller and more homogeneous irrigation systems, usually managed by a single WUA, that generally predominate in that growing literature.

However, the irrigation system of the Huerta of Valencia comprises two different kinds of organizations. On the one hand, the nine old and traditional WUAs which derive surface water from the Turia River, who recently began to use other resources in drought situations, such as Drought Emergency Wells or recycled wastewater. On the other hand, the Groundwater User Associations (GUAs) which are independent organizations located within the Huerta area, although they are smaller and use groundwater exclusively.

Based on comparative ethnographic research, Trawick (2008, 2005, 2001b), has 
argued that profound similarities exist among the rules that local farmers have worked out for sharing scarce resources in different parts of the world. He suggests that equity and transparency - two system characteristics that are vital to adaptive success and longterm sustainability — can often be created by applying a relatively simple set of principles. These principles may turn out to be the same for a great variety of systems, regardless of their scale and level of structural complexity, including the Valencian system.

The principles proposed by Trawick (2008, 2001b): autonomy, contiguity, uniformity, proportionality and transparency (Table 3.1) are known to be applied to surface water use in the Huerta of Valencia-where cooperative use has always been the foundation of the local irrigation system-as Glick (1970), Maass and Anderson (1978), Ostrom (1990) and others have shown. However, in the pages that follow, we will study how other water resources such as groundwater or recycled water, which in recent decades have become increasingly important to the farmers of the Huerta, affect the operation of Trawick's principles.

Valencian farmers have been able to integrate groundwater, recycled and traditional surface water use in a single system. When this occurs, conflict among uses and users has to be solved, new rules may arise for the two new water sources, interacting with the traditional water system. As has been pointed out by some authors, this is not a trivial matter (Blomquist et al., 2004, 1994; Schlager, 2007). In a number of instances, farmers have stopped contributing to the management and maintenance of surface water irrigation systems once groundwater became available (Shah, 2009, 1993). In addition, the reuse of recycled water has been shown to be a valuable strategy to adapt to water scarcity, even though it poses some challenges where farmers' perceptions play an important role (Carr et al., 2011).

The integrated use of those three kinds of resources was crucial in adapting to the recent drought occurring between 2005-2008, an extreme event that is highly likely to recur as climate change continues, as we shall see. Thus, the present work aims to provide a more complete view of this local irrigation system, providing insights about how farmers have integrated ground and recycled water into a traditional irrigation system, to successfully adapt to the drought emergency context occurring between 2005-2008. 
Table 3.1. Basic principles of irrigation in Huaynacotas adapted to La Vega de Valencia (Trawick, 2008, 2001b).

- Autonomy: The community has and controls its own flows of water. The WUAs have exclusive competence on managing the water resources according to their own rules or institutions.

- Contiguity: In this irrigation system, when surface water is used, water distribution follows a contiguous pattern and irrigation order takes place based on the location of each plot. In order to irrigate farmers follow an order of irrigation from top to bottom, canal by canal and plot by plot, until water reaches the end of the sector and one irrigation cycle is finished

- Uniformity among water rights and in technique: Everyone receives water with the same frequency and everyone irrigates in the same way. When a whole irrigation cycle has run and all plots have received water if needed, irrigation can be retaken again upstream ensuring that all parcels have right to irrigate with the same frequency. By obeying the rules and conserving water, farmers are maximizing the frequency of irrigation for themselves and for anyone else; as they will be able to irrigate more often in the long run making the irrigation cycle will run as fast as possible.

- Proportionality among water rights and duties: No one may use more water than the amount to which the extent of their land entitles them; nor can they legally get it more often than everyone else. People's contributions to canal maintenance must be proportional to the amount of irrigated land they have. Proportionality is a consequence of the order of irrigation because the rules establish that no one can irrigate upstream until all parcels downstream in a sector have already irrigated.

- Transparency: Everyone knows the rules and has the capacity to confirm with their own eyes whether or not those rules are generally being obeyed, to detect and denounce any violations that might occur. In Valencia irrigation is a social issue where farmers discuss and keep attention on each other as they are waiting for their surface water turn to irrigate. In addition to free-riding detection, for surface water, effective sanctions or conflict resolution mechanisms under the respected Tribunal de las aguas, are also important to provide security to the water users.

\subsection{Method}

In order to understand the irrigation system rules and underlying principles, but focusing on users' perceptions and opinions, data was collected through a series of inperson interviews with farmers, water officials and members of the management boards of the WUAs and GUAs during the summers of 2008, 2009 and 2010. 23 individuals were interviewed about groundwater use in GUAs. The 23 interviewees were members of 34 out of the 75 GUAs. For recycled wastewater, 35 farmers were interviewed. The sampling was purposive, with the purpose of including interviewees from the different WUAs and having access to the different water sources. Interviewees were contacted while they were irrigating in the different areas. All interviews were conducted using a semi-structured interview guide. The guide included questions where interviewees had 
the option to show agreement or disagreement, on a 5-point Likert scale, and multiplechoice questions, but they were additionally asked to include any considerations and comment on the statements. Furthermore, interviews were conducted with 10 selected persons related to wastewater and groundwater management (the Júcar District Water Authority, the Water Tribunal, the WUAs, a Wastewater Treatment Plant, and a specialized journalist). A comprehensive overview of the kinds of organizations and water resources involved in the irrigation system studied is shown in Table 3.2.

Table 3.2. Different kinds of organizations in the irrigation system of the Huerta of Valencia and water resources managed.

\begin{tabular}{ccll}
\hline Organization & Number & \multicolumn{1}{c}{ Water Resources } & $\begin{array}{c}\% \text { of the area } \\
\text { covered }\end{array}$ \\
\hline WUAs & 10 & River Turia & 100 \\
& & Groundwater from Drought & 67 \\
& & Emergency Wells & 63 \\
GuAs & 75 & Gecycled Wastewater & 78 \\
\hline
\end{tabular}

\subsection{La Vega de Valencia and its irrigation system}

\subsubsection{Historical context and evolution}

Surrounding the city of Valencia, on the central eastern coast of Spain, ten WUAs have been managing water from the Turia River to irrigate an agricultural landscape known as the Huerta, which dates from medieval times and is of Arabic origin. Nine of these ten WUAs meet together in one of the oldest customary courts of Europe, the well-known Water Court or Tribunal de las aguas (hereafter Water Tribunal), with jurisdiction over water conflicts and problems in the area served by these WUAs. The nine WUAs and their Water Tribunal nowadays cover an irrigated area of approximately 4,100 ha, (Table 3.3). This Irrigation System is also known as La Vega, to distinguish it from the neighbouring WUA, the 'Real Acequia de Moncada' (4,600 ha). The latter WUA is not represented in the Water Tribunal and will not be studied here; it follows an internal organization different from the Water Tribunal, although both organizations coordinate and act conjointly on some issues (Maass and Anderson, 1978).

Valencia is characterized by a semi-arid climate consisting of irregular rainfall and seasonal summer scarcity that occurs when irrigation requirements are at their 
height (Carmona and Ruiz, 2007). The predominant agricultural crops in the Irrigation System of La Vega are citrus (22\%) and horticulture (64\%), the remainder consists of rice $(12 \%)$ - located within an area connected with the wetland of the 'Albufera' Lagoon in the WUA of Favara-and ornamental crops (2\%). The Mediterranean climate, in combination with the existing cropping pattern, creates a situation where water is vital for farmers. On the one hand, most horticultural crops require frequent irrigation (weekly during the summer season) and thus the effects of a decreased supply are soon noticed. On the other hand, the time required between irrigation intervals is longer for citrus crops, although the consequences of severe water scarcity may entail irreversible losses in production for the remainder of their productive life. Land-tenure structure is characterized significantly by minifundia; hence it can also be referred to as a "peasant" system (Coward, 1976; Trawick, 2005), or rather as a small-holding system, as most landowners own less than 1 ha, broken up into several small plots across one or more WUAs.

\subsubsection{The irrigation operating principles in Valencia using surface water from the Turia River}

Farmers in Valencia have developed a wide institutional framework which has allowed them to become coordinated and devise a predictable system of water allocation. Water resources for irrigation have been managed for centuries by WUAs that have devised rules for sharing water, minimizing and avoiding conflict when it becomes scarce. Irrigation has prevailed over the long-term, in spite of existing limitations due to a characteristic water scarcity. Trawick proved that a set of operating principles are applied in small Huaynacota communities in Peru (Trawick, 2001b), but pointed out that these principles were also valid for larger communities, such as the Valencian region, and that they contribute to success in local water management (Trawick, 2008). The mentioned principles are presented in more detail in Table 3.1.

Within each WUA in Valencia farmers follow a clearly defined set of rules, even allowing for their complexity, the principles identified in other parts of the world seem to be present in Valencia as well (Trawick, 2008, 2001b). By following these principles, farmers adapt to drastic fluctuations in river flow while maintaining an equitable sharing of water resources. The existing institutions are successful at adapting to drastic fluctuations in water availability, maintaining an equitable sharing between 


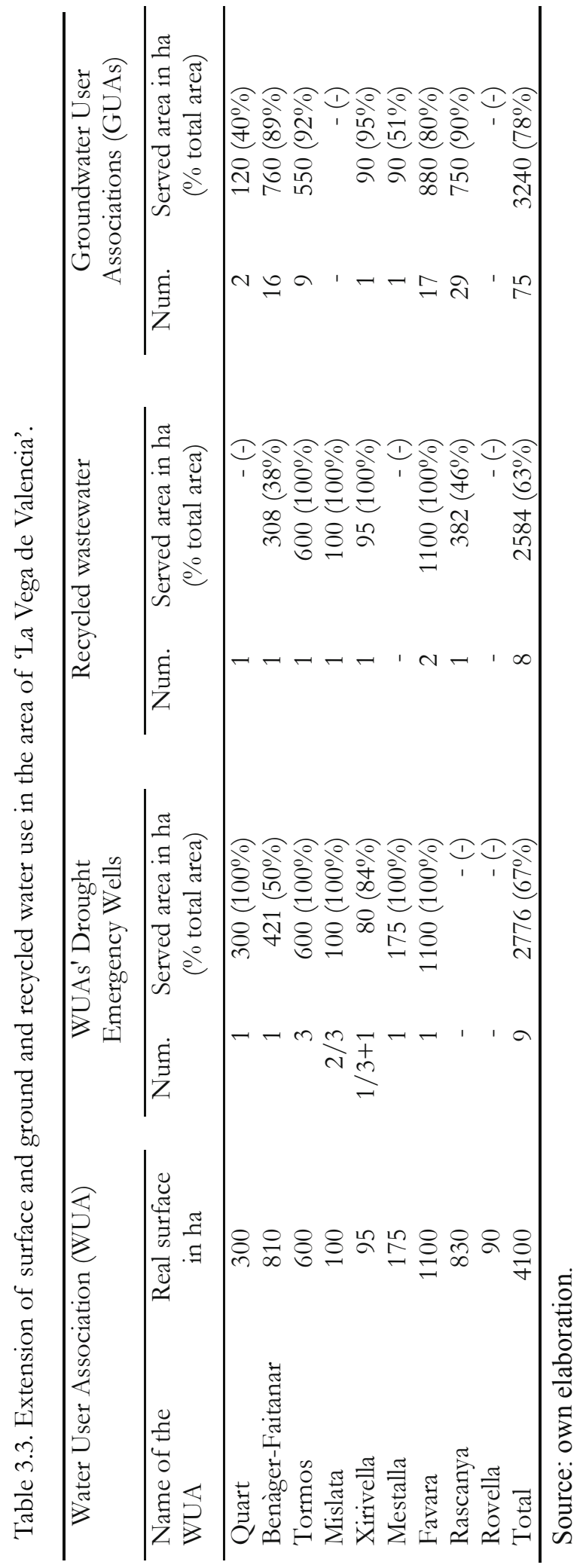


head and tail-enders and minimizing free-riding when there is scarcity. Since farmers have autonomy to distribute their water resources, they have devised their own rules to share the resources and duties in a proportional and uniform manner, in this way creating a strong sense of equity and transparency where individuals have a high level of security about their water rights.

\subsubsection{The importance of infrastructure to maintain uniformity and proportionality} Representatives from WUAs participate in the Comisión de Desembalse (Reservoir Release Commission) of the JDWA ${ }^{16}$, where they propose the amount of water to be delivered to them. Then, according to the established water rights and taking into account water reserves, the Comision de Desembalse decides the amount of water to be released from the upstream reservoirs.

In the channel system, the proportion or water share distributed to each channel and sector depends on two determining factors: infrastructure design and time allowance. Infrastructure design is stable; the amount delivered to each WUA depends on the height of their low diversion dam, although improved regulation is now achieved with sluice gates and channel size determines the maximum capacity. Similarly, the amount delivered to different sectors within a WUA depends on the water-diverting infrastructure. Water-diverting devices, known as partidores, allow water to be diverted from primary to secondary channels and tertiary channels. They are usually equipped with sluice gates, typically made of wood or metal, which are operated manually.

The infrastructure component of the irrigation system cannot be easily changed as it is the result of past agreements on water rights, the well known filas, to share the river flow proportionally according to the amount of irrigated land (Glick, 1970). However, time allowance and flow regulation by means of sluice gates provide the possibility of modifying the proportion of the water delivered or maintaining it by means of time agreements, which are also present in the irrigation system. Currently, WUAs located on the right side of the river (Quart, Benàger-Faitanar, Mislata, Xirivella,Favara and Rovella) irrigate from Monday until Thursday-midday. Afterwards, irrigation is conducted in the ones on the left side (Tormos, Mestalla and Rascanya) until Sunday.

16. The Júcar District Water Authority (in Spanish Confederación Hidrográfica del Júcar) is the public body dedicated to the administration of water and hydrological planning in the Júcar District. The Júcar district encompasses various basins, including the Júcar River District and the Turia River District. 


\subsubsection{Supplementary resources for WUAs}

\subsubsection{Provision of the WUAs' with Drought Emergency Wells}

The construction or operation of emergency wells is a measure to respond to droughts that are more severe or longer than usual. During situations of critical scarcity, WUAs are allowed by the JDWA to use Drought Emergency groundwater sources. The existing Drought Emergency Wells were drilled by the JDWA or the regional government, who have since transferred the duties of operation and maintenance to the WUAs.

This kind of groundwater use has the main function of supplementing river water, increasing the available flow. By doing so, it is possible to irrigate the same area in a shorter time. However, the groundwater resources from Drought Emergency Wells are not in themselves sufficiently abundant to be able to supply the entire service area. For this reason, irrigation with Drought Emergency Wells normally takes place when there is some availability of river water.

The distribution of Drought Emergency Wells by WUAs is presented in Table 3.3. These wells are normally located upstream of the distribution channel of each WUA in order to serve the greatest number of members possible. As shown in Table 3.3, Drought Emergency Wells serve nearly the entire area of the WUA. As these wells are managed by the WUAs and are normally used when surface water is available and as a supplement rather than a substitute, their use follows exactly the same principles of distribution as those applied to surface water irrigation.

\subsubsection{Recycled Wastewater}

In summer 2007, the JDWA agreed with the WUAs on the use of recycled wastewater generated by the city of Valencia (around 1 million people). The recycled wastewater is treated in four main treatment plants located on both sides of the Turia River. In Tables 3.3 and 3.4, and in Figure 3.1, information related to the size and location of each Wastewater Treatment Plant can be found.

This recycled wastewater is managed by the WUA as a supplement rather than a substitute. Even though the introduction of recycled wastewater does not drastically affect the management of the WUAs, when dealing with recycled water it is more difficult to achieve the same arrangements between WUAs as with surface water. This is because the recycled water discharge points are not located at the head of the system in the Turia 
River, but instead discharge directly into a WUA's infrastructure (and not at the head of the WUA either). However, within a WUA, agreements regarding distribution are easier to achieve. Each autonomous WUA is allowed to distribute their available resources (both surface and recycled water), hence they may destine a greater amount of surface water to the areas of the WUA where the infrastructure does not permit the possibility of irrigating with recycled water.

Table 3.4. Flow rates from WWTP $\left(\mathrm{m}^{3} / \mathrm{s}\right)$ derived for each WUA.

\begin{tabular}{ccccc}
\hline & Pinedo & Quart & Carraixet & Paterna \\
\hline Quart & - & - & - & - \\
Benàger & - & - & - & - \\
Faitanar & - & 0.45 & - & - \\
Mislata & - & 0.1 & - & - \\
Xirivella & - & 0.23 & - & - \\
Rovella & - & - & - & - \\
Favara & 0.5 & Surplus water & - & - \\
Tormos & - & - & - & 0.13 \\
Mestalla & - & - & - & - \\
Rascanya & - & - & 0.27 & - \\
\hline
\end{tabular}

\subsection{Autonomy}

The principle of autonomy is maintained by the WUAs because they still self-govern the water once it is in their canals. The farmers were aware of this, although two comments should be noted in regard to this principle. On the one hand, almost 39\% of the interviewees claimed not to have enough information on this issue and claimed that they did not have information on how the wastewater was introduced into the system (Figure 3.2). On the other hand, there was also a small percentage of farmers that believed that the WUAs lost autonomy because the flow rate depends on the wastewater plant, although this is not entirely true because, as mentioned earlier, this water is used to complement the river water.

\subsection{Contiguity, Transparency and Proportionality}

For these three principles, there are no differences between surface and recycled water and their management once the water is in the canals is exactly the same. This statement was confirmed by $100 \%$ of the interviewees (Figure 3.2). The sanctions or conflict resolution mechanisms are also regulated by the respected Water Tribunal; contiguity is 
also maintained when the surface water rota is strictly applied in drought situations; and proportionality is also dealt with in the same way as with surface water, with the same regulations and considerations regarding the types of crop and their needs.

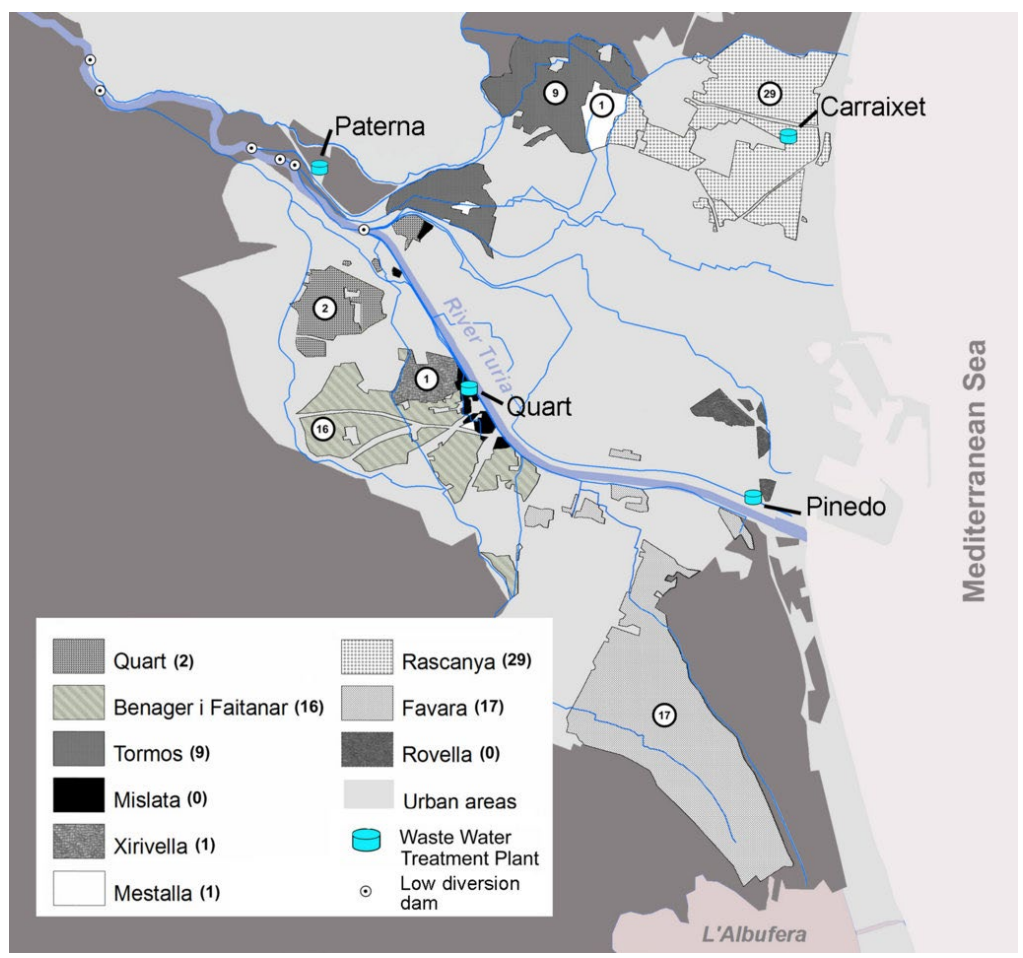

Figure 3.1. Surface irrigated and location of the WUAs in La Vega de Valencia. The number of Groundwater User Associations is shown between brackets in the legend.

\subsection{Uniformity}

As the use of recycled water is comparatively recent, it is not possible to make generalisations in the procedures and uses involved as they may still be evolving. However, the use of recycled wastewater affects the principle of uniformity. In ordinary conditions, WUAs do not renounce surface water but use the additional flow from recycled water to irrigate more often or with a higher volume of water.

\subsubsection{Overall perception of the supplementary resources}

The results show that the existing supplementary resources do not drastically change the way that the system is managed by the farmers. The main difference that appears when 
recycled wastewater is introduced in the system concerns the uniformity in the frequency of irrigation, as the WUAs with access to the wastewater treatment plants have water more frequently (sometimes more than once per week) while the other WUAs have to wait their turn for their resource from the Turia River.

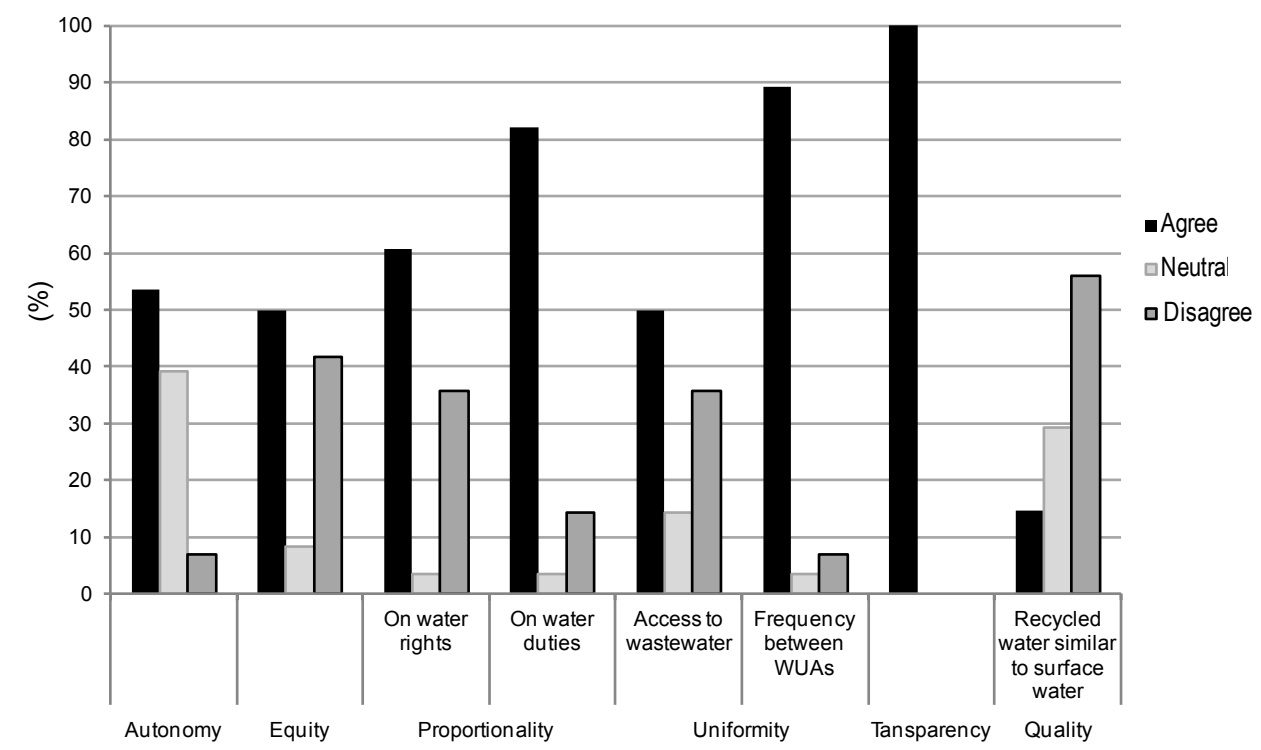

Figure 3.2. Response distribution for questions a about basic principles of irrigation with recycled wastewater.

\subsection{Groundwater User Associations (GUAs). Understanding the overlapping of Water User Associations (WUAs)}

For groundwater use, farmers have formed groups or societies that have drilled wells and who sell water by the hour, to themselves or to other farmers (Maass and Anderson, 1978). Farmers in GUAs manage and maintain a well collectively. These wells are used for irrigation in accordance with the rules of each GUA. The regulation and control of groundwater abstraction is the responsibility of the JDWA. Each GUA has an authorized volume allowance per year regulated by the JDWA but, in most cases, no reliable control mechanisms are enforced. The existing wells are mainly used to overcome the deficit in river water, which itself depends not only on river water availability but also on crop requirements.

These groups exist in the Huerta of Valencia within the same area and are mostly 
comprised of the same users as the WUAs. They use the same distribution system of canals and interact with the WUAs managing the river water; there is overlap among the users' associations in each case.

As shown in Table 3.3, the number of existing GUAs, a total of 75, is significantly higher than the number of Drought Emergency Wells, and they appear to be the most important type of groundwater use. The GUAs studied irrigate a smaller area than WUAs, ranging from 15 to 100 ha and from 30 to 150 irrigators. These associations have typically one or two wells exploited collectively, with a theoretical flow ranging from 2500-6000 $\mathrm{l} / \mathrm{min}$ and a pump with power ranging from 17 to $70 \mathrm{HP}$. Most of the wells have an electric engine, with an average minimum cost of 150 Euros per month whether they use it to irrigate or not. In the GUAs studied, members pay their respective GUA for water by the hour and this revenue is used to cover the ordinary expenses.

As shown in Table 3.3 and Figure 3.1, the distribution of GUAs is not homogeneous throughout the system. Therefore, in three of the larger WUAs (BenàgerFaitanar, Tormos and Rascanya) and Xirivella, this type of groundwater use covers approximately $90 \%$ of the surface; two WUAs only have around $50 \%$ of their surface served (Quart and Mestalla); and two do not have GUAs (Mislata and Rovella).

Several factors seem to have influenced the expansion of groundwater use. First of all, expansion was triggered during drought periods and maintained after that initial investment. Secondly, crop necessities have determined the expansion of groundwater throughout the system, developing more wells in areas where there is a predominance of horticultural crops. Thirdly, downstream areas (Rascanya and Favara) are located in places where the aquifer is shallower, which allows them to exploit less costly and more abundant groundwater. Hence, in downstream areas there are a larger number of GUAs; even though they irrigate smaller areas and have a smaller number of members.

\subsubsection{The operating principles in Valencia in Groundwater User Associations}

As in WUAs, farmers in Valencia have joined together to use groundwater. They have devised rules for water allocation and defined their property rights in order to share water resources equitably and minimize the amount of conflict between irrigators. The operating principles for groundwater in Valencia, together with how its use has been integrated with the use of surface water, will be discussed below. 


\subsubsection{Autonomy}

With regards to their autonomy, GUAs can be considered independent from WUAs. They have their own governing board consisting of a president, a secretary, a treasurer and elected members. They have written rules or a statute for the governance of the association. In addition, the supreme authority is the general assembly which comprises all members of the WUA, and is the body that decides if an investment is made or the service area expanded to include new members. This structure is fairly similar to the one existing in WUAs; nevertheless, they are smaller in scale.

All the interviewees agreed with the statement that GUAs have autonomy to decide how the water resources of the WUA are shared and managed (Figure 3.3). It was pointed out though that this is true when no surface water is flowing through the canals. The reason is that GUAs do not own any distribution network. Subsequently, water is delivered through the canal systems of WUAs. Groundwater from GUAs can only be used to irrigate when river water is not flowing in the canal because, as ensured by the rules of WUAs, if groundwater from GUAs gets mixed with river water, the right to irrigate will always remain with the one irrigating with river water. Both institutions overlap in terms of area and farmers. However, the perception of the farmers reflects their capacity for self-governing.

\subsubsection{Contiguity}

In Valencia, distribution of groundwater from GUAs does not follow a contiguous pattern. A farmer that wishes to irrigate arrives at the well and writes his name on a blackboard. Subsequently the order of irrigation takes place based on the order in which the farmers wrote down their names. Thus, the order is normally set by demand, as $91 \%$ of the interviewees confirmed (Figure 3.3). However, $48 \%$ of the interviewees also pointed out that irrigation would be contiguously applied if so required in the event of scarcity.

\subsubsection{Proportionality and Uniformity}

While in WUAs water rights and duties are proportional to land, two different types of GUAs are found according to how water rights and duties are defined. In the first type, similarly to WUAs, water rights and duties are directly linked to a piece of land; individual rights in the association are acquired by having a plot inscribed in the GUA 
and, in some cases, linked to a fixed number of shares per hectare inscribed (land-shares). Furthermore, farmers contribute to the association costs according to the surface they have. Although all farmers have equal rights to use water according to their entitled land, if water availability allows, the amount of water use is not limited in GUAs. The second type of GUA use a time-share based system. Irrigators own a determined number of shares equivalent to a limited number of water hours per month.

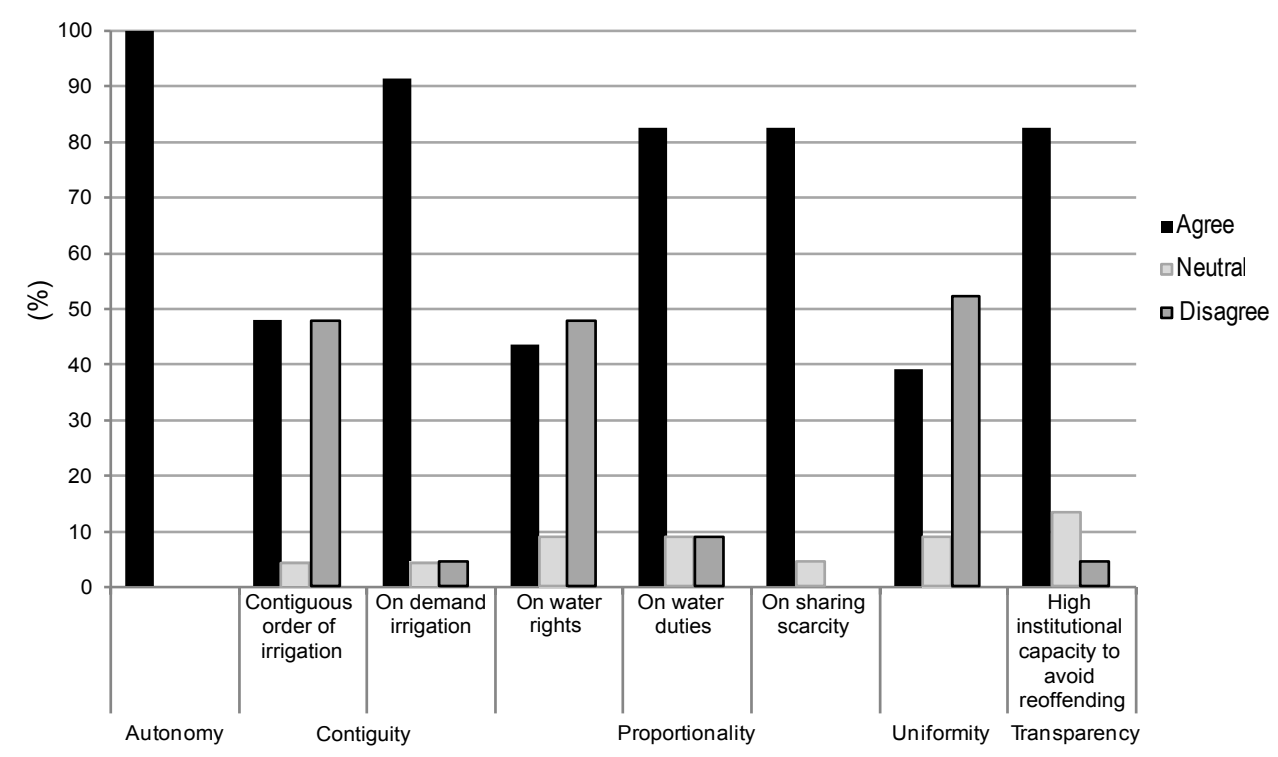

Figure 3.3. Response distribution for questions about basic principles of irrigation with groundwater from GUAs.

These differences, 1) lack of limitation, based on water availability conditions, and 2) use of time-shares, explain why only $43 \%$ agreed with the statement that water rights are proportional to land area in the case of groundwater from GUAs. The main reasons are that, in the second type of association, water rights are proportional to time-shares. In addition, in the first type of association, limitation of water use has not occurred recently as it appears to only happen in extremely severe droughts. However, with regard to water rights rather than water use, this system remains, in practice, very similar to the traditional one because the farmers interviewed have a fairly homogeneous number of shares in proportion to the land they own.

Regarding uniformity, it should be noted that in associations using a time-share 
based system, water rights correspond to a limited number of hours of water per month. Hence, a uniform irrigation frequency is explicitly set according to the number of timeshares owned by each member. In contrast, in the type of GUAs where water rights are linked to land, no limit on groundwater use is established.

Uniformity in irrigation technique is also necessary in order to provide a similar water allowance to every plot, thus achieving proportionality. As observed during fieldwork and confirmed by water officials, the use of drip irrigation is very limited and most of the farmers use gravity irrigation (so called $a$ manta), the fields are levelled so as to have a similar gradient, the use of furrows is compulsory and farmers use fairly similar irrigation procedures throughout the system. Therefore, the uniformity in technique is also present in the case of GUAs as the irrigation distribution network and plots are the same as those employed for surface water use.

It has been observed, however, that in ordinary conditions, groundwater from GUAs is only seldom used due to reasons related to flexibility in schedule. Some reasons may be: avoiding irrigation at night or, in the case of part-time farmers, avoiding lengthy waits for their turn of surface water. However, the main reason interviewees gave for bearing the cost of the wells was the factor of added security in the event of severe water scarcity.

In order to use groundwater, members of both types of GUA are required to pay for water by the hour and to follow the rules of the association. The price per hour is set by the association in order to cover maintenance and operation costs. Furthermore, if the association incurs additional expenses, they are shared among members in accordance with the land, land-shares or time-shares registered. Thus, $83 \%$ of the farmers believed that there is proportionality on water duties according to water use and entitled land or shares (Figure 3.3). In other words, proportionality among rights and duties exists throughout the community, even though it is established in a different way to surface water. In the case of GUAs using a time-share based system, proportionality does not concur with Trawick's definition $(2008,2001 b)$. In these cases, water duties are shared according to water use as there is an established price per hour. Generally, non-members can use the well in times of scarcity — water availability permitting — by paying for water at an additional price. In so doing, members feel that this compensates for the fact that they do not normally participate in the association. Nevertheless, it was mentioned that if non-members require water regularly, they are asked to become members and to 
accept the conditions established by the association.

\subsubsection{Transparency}

The interviews also intended to ascertain the farmers' confidence in the rules and agreements, especially when they fall outside of the jurisdiction of the ancient Tribunal de las aguas, as is the case in groundwater use from GUAs. Most of the interviewees, $83 \%$, agreed that when rules were violated, the fine applied by the GUA would be sufficient to deter reoffending (Figure 3.3). Furthermore, all the interviewees pointed out that this generally does not happen as the level of compliance with the rules is very high.

In order to understand why a strong sense of transparency exists, providing that no contiguous order of irrigation is applied in ordinary conditions, it should be noted that some distinctive characteristics are in place in the case of GUAs. In the first place, GUAs are smaller in scale, which may enhance the role of mutual monitoring. In addition, the right to use groundwater from GUAs is acquired not only by paying an hourly rate, but also by respecting the rules of the association. Moreover, in order to activate the pump independently, farmers use special-purpose coins marked with characteristic grooves. The use of coins is also present in time-share associations, where coins have a number stamped on them that pertains to each member. In this way, the monthly time-use of each member can be monitored in this type of GUA. The use of falsified or similar coins from other GUAs exists, but was reported to be minimal and most of the farmers stated that it is possible to identify the offender because they know which neighbouring plots have the right to irrigate and which not. What is more, one interviewee was warned about irrigating a field that was not registered with the GUA; hence, he was not allowed to irrigate that plot, even though other plots of his property possessed water rights from that same GUA.

Since the use of groundwater from GUAs is dependent on the absence of surface water, its use is more isolated and limited to a smaller area. In these circumstances, farmers believe it is easy to detect free-riding as, when water levels in the canal diminish, they can simply trace back upstream to see where the water is being used. In this case, a farmer irrigating outside of the turn given to him by the GUA will always be causing direct harm to another irrigator. This has been noted by Garrido (2011) as being an important incentive to follow the rules, even more so than when farmers are 
only indirectly affected. Together, these characteristics may help to explain why farmers seem to have high level of confidence in how the system is managed and why a strong impression of transparency exists. These results show that the frequency of water theft, the most disruptive form of free-riding, is extremely low, being virtually nil. The high level of assurance and trust in the existing institutions are an incentive for users to follow the rules.

\subsubsection{Overall perception of GUA management}

The relevance and extent of access to groundwater from GUAs in the traditional irrigation system of Valencia appears to be significant, as its use is widespread throughout most of the system. Even though the use of this kind of groundwater is not uniform throughout the system, most of the farmers do not perceive it as a factor of inequity, as $83 \%$ of the farmers interviewed during the summer of 2009 stated. Rather, it is seen as a complementary source that can be used by farmers who want to have access to it at moments of critical scarcity, thus increasing reliability. This impression may be explained by the fact that cooperation takes place within both institutions. The general perception of the farmers interviewed was that these wells can be used for irrigation by the WUA in cases of severe drought or break-downs in the system, where the cost of the resource is subsequently paid to the corresponding GUAs . Similarly, some interviewees remarked that non-members, who have not contributed to the initial investment and subsequent maintenance costs, can make use of groundwater from GUAs, albeit at a higher price.

Moreover, the principles of autonomy and transparency are also present in the ordinary use of groundwater from GUAs even though these associations are outside of the jurisdiction of the ancient Tribunal de las aguas. Proportionality on water rights and duties exists and is perceived as important but it is not linked, in some cases, to land ownership. Contiguity and uniformity are not ordinarily followed for the application of groundwater from GUAs; nevertheless, a considerable number of interviewees stated that they are applied in case of scarcity. This last aspect will be discussed below.

However, some farmers do not have access to private wells because their plot is located in an area where groundwater use has not been exploited by means of a GUA, or it has been abandoned. In these cases, new licenses for groundwater extraction are extremely limited, therefore not everybody has the chance to use this source to overcome drought conditions. 


\subsection{Adapting to Drought: Integrated Management of Surface, Ground and Recycled Water. Special measures in severe drought emergencies}

This research was partly conducted in summer 2008, in a context of drought emergency, when a reduction by $50 \%$ in the surface water supply had been applied for the previous three years (2005-2008). Although water in Valencia is ordinarily limited, a reduction in frequency does not happen on a regular basis. This situation takes place when the water supply is restricted by the JDWA due to the accumulated deficit in the reservoirs (JDWA, 2003). The main measures to cope with scarcity are restrictions on river water to some crops or alternating supply (tandeo) with the other large WUA irrigating from the Turia River (Real Acequia de Moncada) and the use of complementary resources, such as recycled wastewater or groundwater.

When irrigating in alternation, the WUAs from the Water Tribunal divert all the water available for irrigation for one week, similarly, the following week all the water is diverted by the other WUA (Real Acequia de Moncada), providing the possibility to irrigate with a higher volume of water at the expense of reducing irrigation frequency down to every two weeks at the most.

With regard to the increase of the irrigation cycle to two weeks, it should be noted that, in order to maximize the area served during one irrigation cycle with river water, other supplementary resources, such as groundwater from Drought Emergency Wells or treated wastewater are used in order to increase their available flow. In the same way, field-by-field irrigation was applied with less flexibility. Consequently, as most of the farmers were waiting to irrigate, the surface water turn took place day and night while mutual monitoring became strengthened. Additionally, the rules and basic principles underlying the use of surface water were maintained during drought. By doing so, farmers adapt to water scarcity by extending the irrigation cycle. Thus, they achieve the aim of serving all the users in the WUA if water availability allows for this and, if not, the impact of drought is absorbed equally across all the plots. This supports Trawick's (2008) argument that proportionality on water rights is related to uniformity on irrigation frequency in the case of Valencia. However, access to wastewater and groundwater from GUAs creates inequality across the system. In this sense, there is no uniformity between areas with and without access to groundwater from GUAs.

Another measure used in this period was the restriction on irrigating citrus crops for less than a 45-day cycle, which demonstrates the importance of the drought 
that occurred during this period and illustrates the autonomy of the WUAs to limit the amount of water used in each WUA.

Another way to adapt to the fluctuations on surface water is the relatively recent introduction of new water sources, such as groundwater and recycled wastewater. Even taking into account the differences in uniformity and management in the WUAs and GUAs, accomplishing an integrated use of multiple sources provides a higher reliability of supply and diminishes potential damages; this is happening in Valencia by taking advantage of these new opportunities. The main barrier encountered to a multi-source management by the same organization involves institutional differences. This has been noted by Bomquist et al. (2004) to be a difficult situation to deal with. The introduction of recycled wastewater for irrigation is very recent, dating from less than six years ago. In addition, in the 20th century, groundwater use became possible across the entire system.

For groundwater resources, the conflict that may arise between surface and groundwater use is limited by the existing rules. As GUAs do not have their own infrastructure, farmers willing to irrigate are not allowed to use groundwater at the same time as surface water is flowing through the canals. Except in the case of informal agreements, surface water use has priority over groundwater from GUAs. In addition, the higher groundwater price is also an incentive to continue using surface water when it is available.

For recycled wastewater, water is used as a supplementary resource for those WUAs with access to the wastewater plants. During the drought of 2005-2008, the use of recycled wastewater introduced a difference in uniformity between the WUAs of the Tribunal, as the WUAs with access to recycled wastewater could irrigate with more frequency at a constant flow rate.

Nonetheless, even if WUAs with access to recycled wastewater renounce a part of the surface water flow, they could be able to irrigate every week. Meanwhile, WUAs without access to recycled wastewater were able to irrigate only once every two weeks. This was confirmed by $40 \%$ of the interviewees, who considered that the use of wastewater has introduced inequality in the water distribution system. Moreover, around $60 \%$ of the farmers claimed that the quality of recycled water was not the same as that of river water, although they agree to relinquish their rights to river water in a drought emergency only if they recover their access to it once the emergency is over (Figure 3.2). However, this was not perceived as a lack of uniformity by almost $50 \%$ of 
the farmers, who argued that the increase in frequency was offset by the reduction in quality of the recycled water. In addition, $90 \%$ of the farmers agreed that the frequency is the same within the WUA and farmers from one WUA had the right to irrigate with the same frequency (Figure 3.2).

The system, in all its complexity, has quickly adapted to this resource and the farmers use it in the same way as the river water. Nonetheless, the fact that the water discharge point is not at the head of the system means adjustments on water distribution have to be made in order to share available water resources fairly (as perceived by farmers) within one WUA. In this sense, surface water may be used upstream of the discharge point in order to compensate for not being able to use recycled water for irrigation, as is the case further downstream.

\subsection{Conclusion}

This research has shown that the existing institutions have devised a community-based system that is successful at managing surface water resources that integrate recycled water and groundwater. Since farmers have autonomy to distribute their water resources, they have devised their own rules to share the resources in a proportional and uniform manner. Thus, this has created a strong sense of equity and transparency where individuals have a high level of security about their water rights.

Moreover, the use of additional resources such as groundwater from Drought Emergency Wells or recycled wastewater in the system has not produced any conflict. They were used intensively in periods of severe drought as a supplementary more than a complementary resource. Although it seems mainly to affect the uniformity between different WUAs, when extraordinary measures are applied, such as tandeo, farmers do not perceive this situation as inequitable because the WUAs with access to the wastewater plants or emergency wells temporarily renounce their right to the Turia River water.

The relevance and extension of the access to groundwater and recycled water seems to be significant in the traditional irrigation system of Valencia, as it is widespread over some areas. Even though the use of groundwater and recycled water is not uniform throughout the system, farmers do not perceive it a source of inequality or conflict but rather as a complementary source that can be used by farmers who want to have access to it at times of critical scarcity, increasing reliability. Despite the fact that WUAs and GUAs are not the same organization, nevertheless it seems that the collective and 
overlapping management of both sources results in an effective strategy for adapting to drought. However, it should be noted that the predominating informal conjunctive use may exclude plots not inscribed with GUAs. Therefore, having a higher reliability of supply entails the duty of cooperating with the GUA and contributing to its associated costs in the long-term.

In addition, the principles of autonomy, proportionality and transparency are also present in the ordinary use of groundwater from GUAs. However, it was strongly suggested that contiguity and uniformity be applied in the event of scarcity because, in the view of the farmers, it is characteristic of a correct and equitable water management.

In general, it is possible to conclude that collective management in Valencia occurs not only for surface water but also for supplementary resources such as recycled wastewater or Drought Emergency Wells, and for complementary resources such as groundwater in GUAs, thanks to a simple set of rules and strict self-monitoring between farmers. 


\section{Institutional and Management Implications of Drip Irrigation Introduction in Collectively Managed Irrigation Systems in Valencia}

Ortega-Reig, Palau-Salvador, García-Mollá, SanchisIbor, Avellà-Reus (2015), (manuscript).

\subsection{Introduction}

Water in Spain is scarce, mainly due to a semi-arid climate and strong competition over water resources. The expansion of agriculture together with tourism and urban development has led to water demand exceeding availability, resulting in scarcity, overexploitation of groundwater and damage to ecosystems from reduced water flows to rivers and wetlands (OECD, 2008). For these reasons, the need to reduce water consumption has become a priority in agricultural policy.

The region of Valencia is located in the Júcar District, where $80 \%$ of the total water demand corresponds to agriculture (JDWA, 2014a). In the region of Valencia there are 285,701 ha of irrigated land, $44 \%$ of the total agricultural area in the region. In 2014, the distribution of the different irrigation systems was: 91,585 ha $(32 \%)$ of gravity irrigation and 192,267 ha (67\%) of drip irrigation. Drip irrigation has increased by 83,400 ha $(77 \%)$ since 2004 , whereas gravity irrigation has decreased by 54,642 ha (37\%) (MAGRAMA, 2015a).

In the Spanish context, drip irrigation implementation can be divided into two phases. The first phase consists of early drip irrigation implementation arising from the initiative of individual farmers. The second phase, consists of the development of projects in the framework of the Spanish National Irrigation Plan (Ramón-Morte, 1995; Sanchis-Ibor et al., 2016). The Spanish National Irrigation Plan represents an important initiative of the Spanish national and regional governments (with strong support from European Union funding) consisting of investment and subsidies to promote a shift towards drip irrigation.

More than a decade after the introduction of the Spanish National Irrigation Plan, 
little information is available on the effects of drip irrigation implementation and water use, with large differences between data sources and problems of lack of transparency (López-Gunn et al., 2012b; OECD, 2010; WWF/Adena, 2015). Furthermore, the plan included measures to train farmers and technicians, to evaluate irrigation systems and to improve water management. However, a clear monitoring and evaluation plan and a careful analysis of the results (from an economic, social and environmental point of view) of this large investment program is still missing (López-Gunn et al., 2012b).

Irrigation and water management policies are facing important and complex challenges. Regarding the technical aspects, there is an ongoing debate about the misunderstandings the term 'efficiency' generates, especially when improvements in efficiency are assumed to imply the creation of more available water (Clemmens and Molden, 2007; Jensen, 2007; Perry, 2008, 2007; Perry et al., 2009; Ward and PulidoVelazquez, 2008). Allan (1999) and Playan and Mateos (2006) question this focus on improving technical efficiency in projects driven by the public sector. The authors argue that this alternative is an uncompromised solution that creates no clear losers, in comparison with the improvement of water management, which also needs to be addressed. Other voices claim drip irrigation is generally promoted as an innovation that implies efficiency, productivity and modernity (van der Kooij et al., 2013a; Venot et al., 2014), although this assumption requires more solid evidence (van der Kooij et al., 2013a, 2013b).

This technology-centered perspective has paid little attention to farmers, their practices and reasons for adopting drip irrigation (van der Kooij et al., 2013a; Venot et al., 2014). In this sense, some authors argue that drip irrigation performance is context specific (Garb and Friedlander, 2014; Medellín-Azuara et al., 2012; Sanchis-Ibor et al., 2016) and needs to include the perspective of users (Benouniche et al., 2014a, 2011; van der Kooij et al., 2013a; Venot et al., 2014). Some authors also noted the importance of users understandings of performance, as in some cases irrigation practices and reasons for adopting drip irrigation were scarcely related with water savings but with ease of use, labor reduction, increasing quality or quantity or the product, field slope or increasing the irrigated surface (Benouniche et al., 2014a; van der Kooij et al., 2013a). Gómez-Espín et al. (2006) noted the importance of the participation of farmers in drip irrigation projects, and also to assess their perception and satisfaction to achieve a positive implementation. 
In the Spanish context, water is public. District Water Authorities are the responsible bodies for the management of water at basin level, the regulation of water allowances and the delivery of water up to WUAs or user intake. In addition, throughout the Mediterranean area there is a longstanding tradition of collective irrigation management. In Spain, there are more than 7,000 registered WUAs. WUAs are regulated under the current Water Law, dating from 1985, as groups of irrigators that hold collective water rights. They are autonomous to manage and distribute water in a particular irrigable area and they have their own bylaws regulating water management and their organizational arrangements.

Understanding the process of adopting new technologies and practices is a requirement for the formulation of water management policies. The adoption of agricultural technology has been addressed using approaches that model decisions, based on the different characteristics of farmers and regional aspects (Fissel et al., 2013; Koundouri et al., 2006; Medellín-Azuara et al., 2012; Shrestha and Gopalakrishnan, 1993; Sunding and Zilberman, 2000). In addition, other authors have shown the significant role of the motivations and perceptions of farmers to explain the implementation of technologies or conservation practices (de Graaff et al., 2008; Greiner et al., 2009; Greiner and Gregg, 2011; Kessler, 2006; Marra et al., 2003). This process has also been framed using systemic approaches focusing on social-technical interaction (Garb and Friedlander, 2014; Jansen and Vellema, 2011). However, most of these approaches have focused on the adoption of new technologies or practices as an individual choice.

From an institutional point of view, the implementation of drip irrigation in the Spanish context entails an important shift in rules and institutions for collective irrigation management (López-Gunn et al., 2012b). Although drip irrigation implementation projects conducted under the Spanish National Irrigation Plan framework have mostly been initiatives of WUAs, the involvement from farmers in the design and implementation of the projects has been moderate. Collective conversion from sprinkler to drip irrigation in the Gharb (Morocco) has shown how farmers have adapted drip irrigation practice to their own needs from what was proposed in the initial project (Benouniche et al., 2011). Similarly, in the case of Morelos (Mexico) groups of farmers have appropriated this technology and implemented it by themselves (González-Pérez et al., 2013). In addition, Kuper et al. (2009) have shown that collective drip irrigation projects require a broad shared understanding of irrigation management (technical, 
economic, social, etc.). These cases contrast with farmers implementing the technology directly, as in other cases in Morocco or India (Ameur et al., 2013; Benouniche et al., 2011; Venot et al., 2014), or with drip irrigation schemes driven by the public sector and given to farmers in the form of turnkey projects (Venot et al., 2014).

In Spain, where promoting irrigated agriculture has been a basis of social development in the 20th century, drip irrigation programs are the logical evolution of irrigation policy towards improving productivity and the quality of life of farmers (e.g. avoiding irrigation turns and irrigation at night) and increasing the guarantee of supply and the flexibility of crop choice.

Changes in technology imply uncertainty, but also reshaping of the technical and institutional aspects (Benouniche et al., 2014b). The first objective of the work is to analyze the reasons for shifting to drip irrigation, from the perspective of both farmers and WUAs. The second objective is to assess the main changes occurring regarding the management of this technology, both in the organizations in charge of irrigation management and at the level of farmers.

The paper is structured into the following sections: Section 4.2 presents the methods and describes the case studies; Section 4.3 analyzes the reasons WUAs and farmers give for shifting to drip irrigation; Section 4.4 presents and discusses selected aspects of the technical change; Section 4.5 analyzes the perception and satisfaction of farmers; and Section 4.6 draws a conclusion.

\subsection{Method}

In order to understand drip irrigation uptake and use, data was collected through a series of in-person semi-structured interviews with farmers and managers of the WUAs during the summers of 2011 and 2012. In total, 82 farmers were interviewed. Interviewees were contacted in the field ( 60 of them) or by means of the WUA ( 22 of them). The 70 interviewees who had drip irrigation were further interviewed about their reasons for adopting drip irrigation, and regarding irrigation and fertigation management, training received, differences observed with gravity irrigation, general evaluation and also the general characteristics of the individual farmer (age, size of the exploitation, crops, and dedication).

In addition, interviews were conducted with the managers of 5 WUAs: the WUA of the Acequia Real del Júcar; three WUAs from the Júcar-Túria Channel (JTC) and a 
WUA in the Vall d'Uixò Valley. The interview guide included the following subjects: general characteristics (irrigated surface, number of members, drought experiences and water use), reasons for adopting drip irrigation, difficulties involved in the process, previous existing water conservation measures, training for farmers and changes in the rules, water delivery system and irrigation management.

A comprehensive overview of the organizations and the water resources used in the irrigation system studied is shown in Table 4.1.

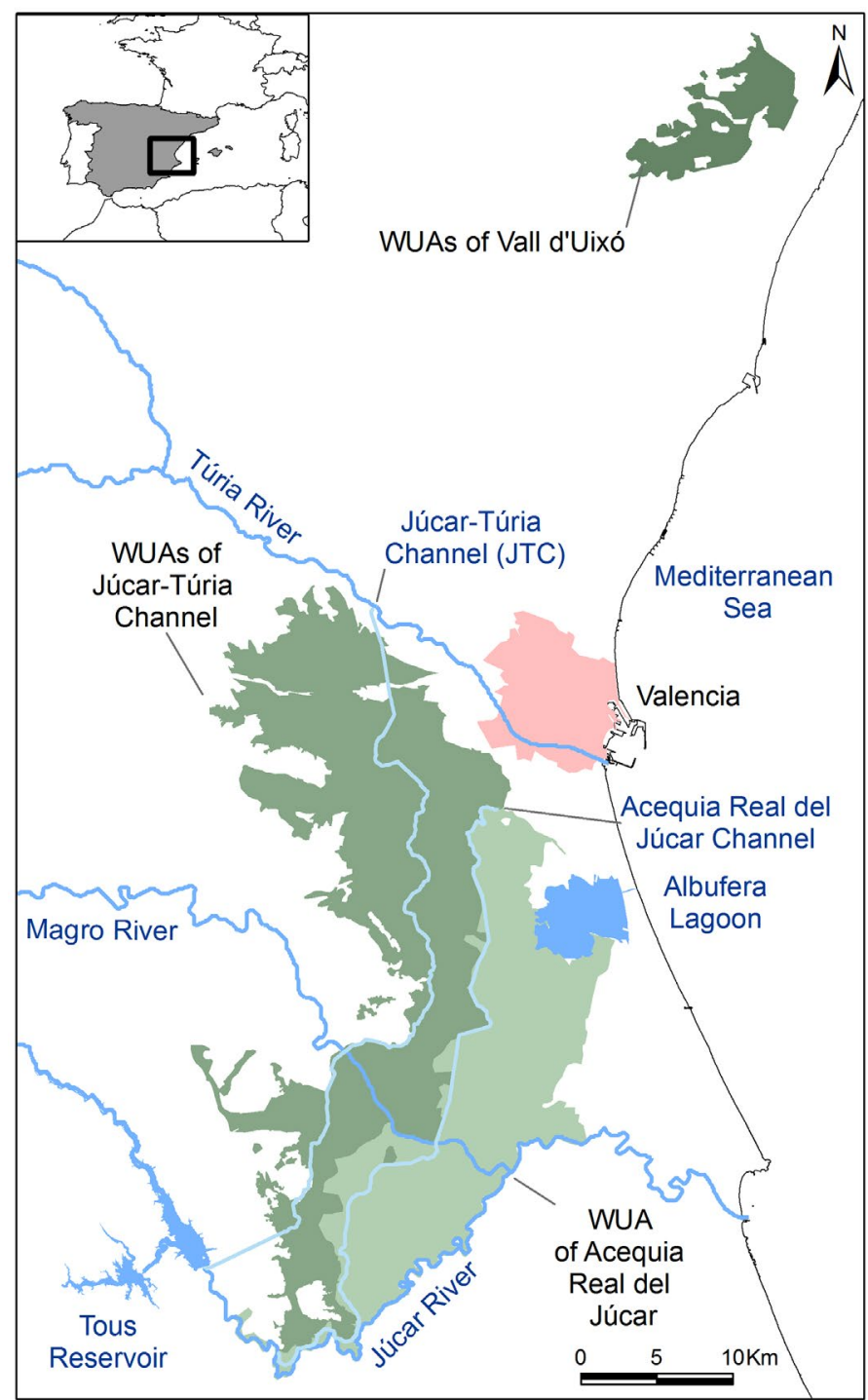

Figure 4.1. Location of the case studies analyzed. 


\subsubsection{Case study description}

The study area is located in the Valencia Region (Figure 4.1). Valencia is characterized by a semi-arid climate consisting of irregular rainfall (the average rainfall ranges from 400 to $600 \mathrm{~mm}$, generally involving a lack of rainfall in July and August), seasonal summer low water at the moment of maximum irrigation requirements, and drought with a recurrence interval of approximately 10 years. In the studied area, water resources are scarce and under increasing pressure due to competition with other agricultural, urban, industrial and environmental uses.

The areas studied are characterized by small-scale agriculture (the average exploitation size is $2.66 \mathrm{ha}$ ), part-time dedication ( $86 \%$ of farmers dedicate less than $50 \%$ of their working time to farming activities), use of family workforce (only $23 \%$ of farmers have temporary or permanent employees) and the high age of farmers (approximately $40 \%$ of farmers are over 64 years old, 26\% are between 64 and 55 years old, $20 \%$ are between 54 and $45,10 \%$ are between 44 and 35 years old and only $3 \%$ are below 35 years old) (NSI, 2009).

\subsubsection{Acequia Real del Júcar (ARJ)}

The origin of the ARJ dates back to 1258 . The channel was extended in the 18 th century to bring water to the Albufera wetland. As a juridical indication of its antiquity, this WUA has preference over other agricultural users in the Júcar River Basin (e.g. the areas irrigated by the JTC).

The total irrigated surface today covers 19,437 ha and uses surface water from the Júcar River. The most dominant crops are citrus (orange and mandarin) and persimmon. The latter is currently experiencing a rapid expansion to the detriment of citrus cropping. Rice production, limited to the area surrounding the Albufera Lagoon, and intensive horticulture (comprising two or three crops per year) are also important (Carles-Genovés et al., 2008).

In the case of the ARJ, there is a governing board that covers the whole irrigation area and 21 local governing boards whose area of influence is the irrigated area at municipality level (Figure 4.2). The Governing Board has ten members that make decisions regarding the administration of the ARJ. Each local governing board has its own council of users (comprising all irrigators in the district), a management council and an irrigation jury. Once a year, all 30 representatives of the local councils attend 
a general assembly, from which the ten members of the Governing Board are chosen (Carles-Genovés et al., 2008; Pimentel Equihua, 2006).

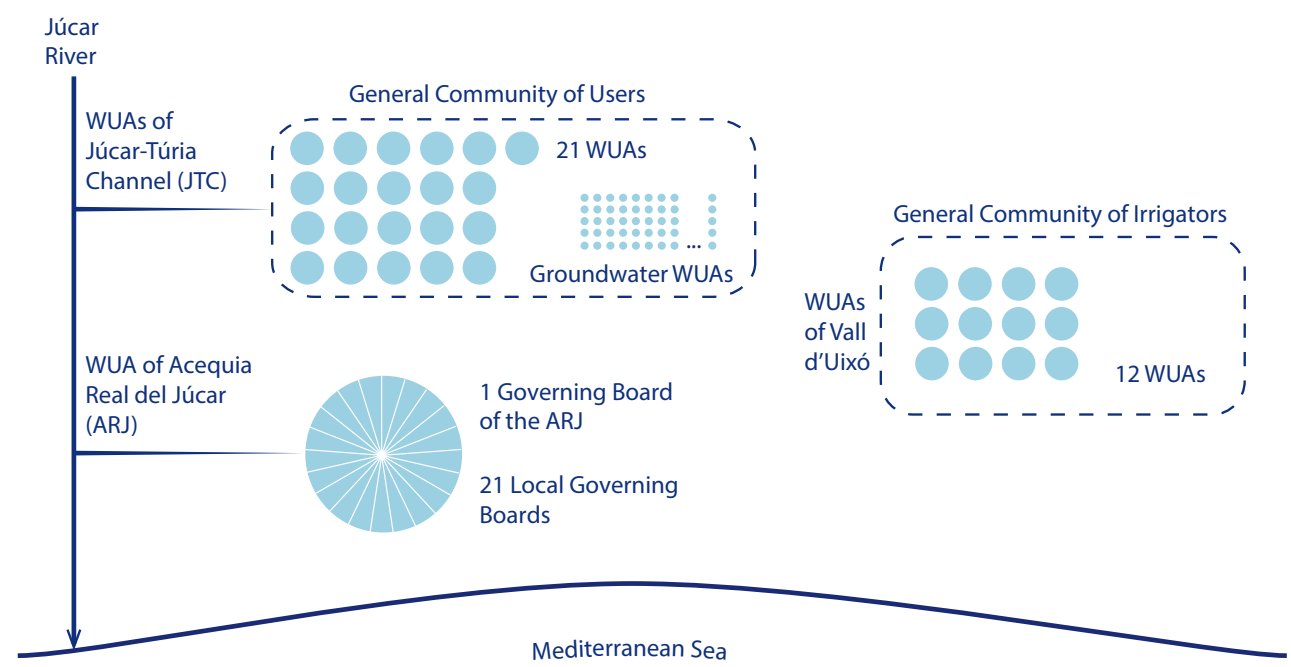

Figure 4.2. Scheme of the organizations of the analyzed case studies.

\subsubsection{General Community of Users of the Júcar-Túria Channel (JTC)}

The JTC is a water transfer channel from the Júcar to the Túria River built in 1978. Before the construction of the JTC, there were also Groundwater User Associations, formed by landowners who came together to drill and exploit a well, and small spring irrigation systems dating back to Arab times or the Middle Ages. The channel was conceived to ensure water supply to the city of Valencia and to create new irrigation lands. WUAs of the JTC use both surface and groundwater to irrigate.

The total irrigated area covers 17,953 ha approximately. Citrus is the dominant crop, but recently persimmon and other fruit trees are gaining importance. At WUA level, conjunctive management of water resources (Foster et al., 2010; Shah et al., 2006) is conducted by irrigation administrators. The volume of surface water supplied is assigned by the Júcar District Water Authority and they use as much surface water as possible because the price of water paid to the Júcar District Water Authority is lower than groundwater pumping costs. When restrictions in surface water are applied, they increase groundwater extraction to compensate for the deficit of surface water.

Water management is currently conducted by the General Community of Users 
of the JTC, created in 1985. It comprises 21 WUAs grouped in the General Community of Users of the JTC (Figure 4.2). Each of these WUAs has an individual water allowance regulated by the Júcar District Water Authority. The government organs of the General Community of Users of the JTC consist of a General Assembly of Users (36 members), a governing board composed of one member of each WUA, Valencia and Sagunto town halls (23 members). In addition, there is an irrigation jury composed of 7 members.

\subsubsection{General Community of Irrigators of Vall d'Uixó}

Irrigation in the area was developed during the 20th century, mainly based on groundwater use. Out of the 2,932 ha with irrigation rights only 2,395 ha are irrigated, as a result of a decrease in irrigation in the past years (mainly due to urban growth, and abandonment related to the ongoing crisis in the citriculture market). The main crop is citrus fruits, especially mandarins. Landholding structure is characterized by minifundia, as reflected by the number of members in the General Community of Irrigators, adding up to 3,996 (García-Mollá et al., 2013).

Groundwater is managed collectively by 12 WUAs. They come together in the General Community of Irrigators of Vall d'Uixó (Figure 4.2). This organization conducts the administration and represents the irrigation associations before the Government. However, each WUA manages its own water sources for irrigation and has a water allowance. In total there are 56 boreholes (12 are not in use), with a depth ranging from 40 to $299 \mathrm{~m}$.

\subsection{Reasons for adopting drip irrigation}

\subsubsection{Reasons for adopting drip irrigation, by Water User Associations (WUAs)}

Beyond other factors, water conservation is the main or critical reason these WUAs have adopted drip irrigation, due to the growing pressure on water resources in the region. After various decades of significant investments on concrete lining of irrigation channels, drip irrigation was perceived as the logical step in the technological process for reducing the agricultural use of water. Drip irrigation, entrenched within a powerful discourse of modernization, was irresistible for those WUAs facing scarcity or growing competition for water resources throughout the region. 
Table 4.1. Main characteristics of studied areas and farmers interviewed.

\begin{tabular}{|c|c|c|c|}
\hline & \multicolumn{3}{|c|}{ Water User Associations (WUA) } \\
\hline & $\begin{array}{l}\text { Júcar-Túria } \\
\text { Channel }\end{array}$ & $\begin{array}{l}\text { Acequia Real del } \\
\text { Júcar }\end{array}$ & Vall d’Uixó \\
\hline Irrigated area (ha) & 17,953 & 19,437 & 2,395 \\
\hline Area with water rights (ha) & 24,952 & 20,169 & 2,932 \\
\hline Farmers (number) & 35,000 & 29,403 & 3,996 \\
\hline Water allowance $\left(\mathrm{Mm}^{3} /\right.$ year $)$ & $95^{\mathbf{a}}$ & 212.3 & $13.6^{b}$ \\
\hline \multicolumn{4}{|l|}{ Water source in $2009\left(\mathrm{Mm}^{3}\right)$} \\
\hline Surface water & $95.7(63.51 \%)$ & $220.5(99.86 \%)$ & \\
\hline Groundwater & $54.9(36.49 \%)$ & $0.3(0.14 \%)$ & $14.8(90.80 \%)$ \\
\hline Treated wastewater & & & $1.5(9.20 \%)$ \\
\hline Total & 150.7 & 220.8 & 16.3 \\
\hline \multicolumn{4}{|l|}{ Demand in $2009\left(\mathrm{Mm}^{3}\right)^{\mathrm{c}}$} \\
\hline Net & 99.4 & 107.0 & 10.7 \\
\hline Gross & 150.7 & 220.8 & 16.3 \\
\hline $\begin{array}{l}\text { Gross summer } \\
\text { (April-September) }\end{array}$ & 123.6 & 159.8 & 14.8 \\
\hline $\begin{array}{l}\text { Gross winter } \\
\text { (October-March) }\end{array}$ & 27.1 & 61.1 & 1.5 \\
\hline \multicolumn{4}{|l|}{ Crops $(\%$, allowance } \\
\hline Citrus fruit trees & $57 \%, 4,050$ & $58 \%, 4,050$ & $96 \%, 3,827$ \\
\hline Other fruit trees & $39 \%, 4,050$ & $8 \%, 4,050$ & \\
\hline Horticulture & $4 \%, 2,566$ & $11 \%, 4,600$ & \\
\hline Rice & & $22 \%, 9,400$ & \\
\hline Other & & & $4 \%, 3,125$ \\
\hline \multicolumn{4}{|l|}{ Irrigation system (\%) } \\
\hline Surface gravity & 38.7 & 77.8 & 4.0 \\
\hline Drip & 61.3 & 22.2 & 96.0 \\
\hline Theoretical efficiency $(\%)^{d}$ & 65.9 & 50.8 & 64.5 \\
\hline $\begin{array}{c}\text { Interviewed number of } \\
\text { farmers }\end{array}$ & 39 & 32 & 11 \\
\hline
\end{tabular}

Source: Prepared by the author, based on the Júcar District Management Plan (JDWA, 2014a) and data obtained from interviews with Water User Associations.

a The WUAs of JTC water allowance refers only to surface water resources, although they are also irrigated from groundwater sources. They have 55 additional $\mathrm{Mm}^{3} /$ year corresponding to surface water rights that cannot be attended due to the lack of available resources.

b The water allowance in WUAs of Vall d'Uixó includes $11 \mathrm{Mm}^{3}$ from groundwater resources, $1,1 \mathrm{Mm}^{3}$ from springs and $1,5 \mathrm{Mm}^{3}$ from treated wastewater.

c The demand in 2009 is calculated in the Júcar District management plan according to the established net crop water allowance for different established agricultural areas.

d The theoretical efficiency is established in the Júcar District Management Plan, assuming in the case of the ARJ that only $6 \%$ of the area uses drip irrigation. 
At the Vall d'Uixó valley, during the decade of 1980, 19 WUAs were using groundwater resources for irrigation. Farms belonging to these WUAs were scattered and interspersed over the whole valley, and irrigable areas overlapped. For this reason, irrigation networks were too long and frequently crisscrossed, causing low irrigation efficiency and an unusual water consumption for citrus areas (higher than 10,000 m3/ ha). Year after year, water pumped exceeded the aquifer recharge rate. As a result of this intensive use of groundwater, marine intrusion and aquifer salinization severely affected most of the irrigation wells (Barba-Romero et al., 1998).

In 1989, the WUAs created the General Community of Irrigators of Vall d'Uixó, following the legal obligation (in case of groundwater overexploitation) to constitute a collective institution for water management. The aim was to regulate groundwater use due to the existing salinity and water shortage problems. The creation of this organization did not improve groundwater levels and, at the beginning of the 21 st century the General Community of Irrigators of Vall d'Uixó decided, together with the public administrations, to introduce drip irrigation. The aim of this change was to reduce the amount of water pumping, by introducing an irrigation technique widely considered as more efficient, but also through the reorganization of the overlapping irrigation network. Thus, drip irrigation was part of a wider modernization and integration plan, partially subsidized, which involved a complete redesign of the common irrigation network, and concentrated pumping on the best-preserved wells.

At the Júcar River Basin, pressure on water resources also markedly increased at the end of the 20th century, mainly because of the expansion of agricultural uses in La Mancha Region (upstream). In light of this situation, the Júcar District Management Plan of 1998 considered the modernization of the low Júcar irrigation systems as a strategic option to preserve the balance between uses and resources in the whole basin. This was the main reason why many irrigation systems of the Valencia region obtained public subsidies to stimulate drip irrigation installation. Throughout the first decade of the current century, the WUAs belonging to the JTC obtained public grants to subsidize part of the modernization project costs $(60 \%)$, and the rest of the investment was financed by the WUAs.

In the case of the ARJ, the ultimate purpose of this transformation to drip technology was specifically to release water resources for other agricultural uses. Water use reductions to be achieved at the ARJ through drip installation were allocated to 
meet the demands of the Vinalopó Valley (Province of Alicante) through an inter-basin water transfer. This goal was defined in the 1998 District Management Plan, and in 2001, the Ministry of the Environment, the regional government and the ARJ signed an agreement that, among other actions, stipulated the complete and non-refundable subsidization of the drip irrigation project of the ARJ and other traditional irrigation systems of the lower Júcar Valley.

The public administrations have played an influential role in the decisionmaking processes of these institutions. Since the severe drought of 1995, both the regional and the central government have had a strong commitment to reducing the agricultural use of water, and drip irrigation has been selected as a strategic tool to reduce water withdrawal in this sector. It has been promoted and subsidized by national and regional governments, which have developed modernization plans and projects at district or sub-basin scale. These economic and technical contributions have facilitated the involvement of WUAs in the technological shift.

The decision to introduce drip irrigation was made by the governing boards of these WUAs, and subsequently approved by their general assemblies. Interviewed members of the WUA governing boards highlight water conservation as the main or critical element for adopting this technique, although they also cited other reasons. One of the main advantages stated by four out of five WUAs was having a more convenient or comfortable irrigation system (with fewer duties to be conducted by the farmer). In addition, two WUAs mentioned fertilizer savings (due to centralized management and economies of scale) and one of them mentioned a main advantage of obtaining an increase in production.

\subsubsection{Reasons for adopting drip irrigation, by farmers}

When looking at the responses of farmers (Figure 4.3), the first reason for adopting drip irrigation was due to obligations from the WUA (50\% of the farmers interviewed), followed by: to obtain an increase in production (16\%) and to save water (9\%). When looking at other drivers (2nd and 3rd reasons), reasons such as obtaining an improved product quality, convenience of the technique, knowing about the experience from other WUAs, economic and labor savings were mentioned by at least $10 \%$ of the farmers.

In order to understand why $50 \%$ of the farmers mentioned were obliged to implement drip irrigation, it should be noted that the decision was taken at WUA level. 


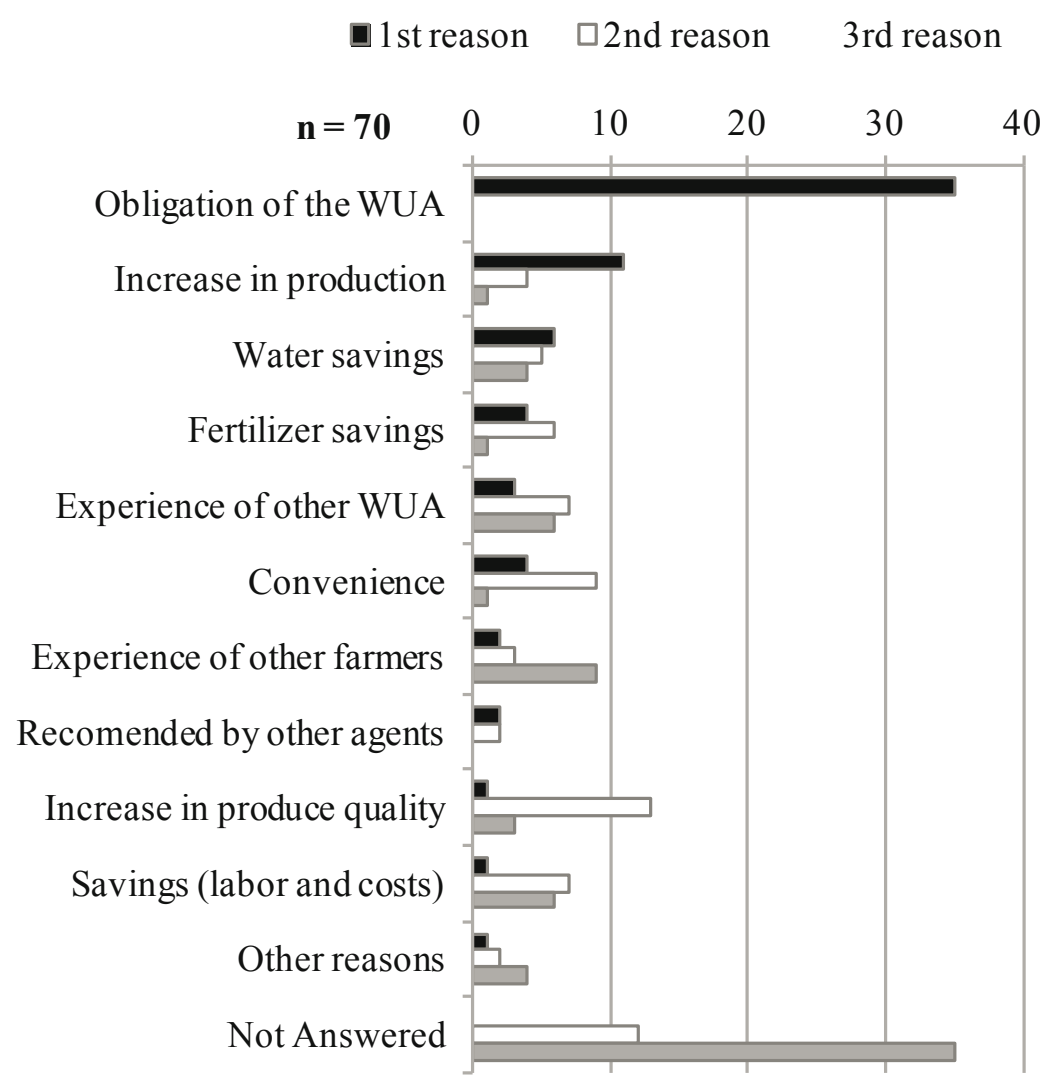

Figure 4.3. Response distribution for the reasons for adopting drip irrigation.

Even though the shift to drip irrigation had been approved by their general assemblies, the participation of farmers in these assemblies is usually low. Hence, if they did not adopt the technology they could not continue irrigating in many cases. In addition, some WUAs have a higher water price for furrow than for drip irrigation (an incentive to adopt drip irrigation), or the existing channels are in increasingly worse state due to lack of maintenance and as a result of the majority of farmers shifting to drip irrigation (increasing water use and hence the water cost where they pay an amount related to water use).

Another highlighted aspect of drip irrigation implementation was the fact that the decision to implement drip irrigation (at WUA level) was taken in a context of the citrus harvest being well valued. Currently, this is not the case with citrus fruit in the Valencia Region. Some of the farmers interviewed mentioned that they felt deceived, 
because drip irrigation implementation was recommended as 'something that should be done'. In some cases they say they were told it was for free, subsidized, and now some of them are experiencing financial difficulties.

When looking at the farmers who did not adopted drip irrigation, most of them mentioned they did not yet have the possibility to connect, but would do so as soon as the project was finished. Land tenancy and organic farming (if centrally managed fertigation is applied) are other factors hindering the uptake of drip irrigation.

\subsubsection{WUAs measures to stimulate drip irrigation uptake among farmers}

Once the WUA invests in a new infrastructure and the project is finished in a certain area, farmers can connect to the network. In the JTC, one WUA mentioned having 5\% of farmers not connected, and another mentioned having a range somewhere between 30 to $40 \%$ (they finished the drip irrigation project in 2008). In the case of the ARJ, $14 \%$ of farmers are not connected (in areas where drip irrigation is available).

If the number of farmers not connected to the network were very high, it would pose serious financial problems for the WUA. In order to solve or to prevent this problem, some WUAs made it compulsory to install drip irrigation or set a higher price to discourage gravity irrigation. By contrast, one of the interviewed WUAs from the JTC does not oblige farmers to connect. The managers argued farmers are already experiencing a difficult situation. In the case of the ARJ, they give a maximum deadline of three years to connect to drip irrigation. In addition, in order to connect they sign an agreement for complying with the obligation of paying drip irrigation network maintenance, even in case of future application for termination of the service.

In the case of the ARJ, the obligation to connect is a measure that may not be accepted easily. Subsequently, during the informative meetings for farmers, conducted when the drip irrigation service is going to start in an area, they clearly explain the justifications of the WUA. Some of the arguments used are legal: water law mentions that water allowances may be reviewed by the Júcar District Water Authority when the same task can be conducted with less consumption or with an improvement in technique that contributes to a better use (BOE, 1985, sec. 65.2). Other arguments are related to the collective interest of the WUA in general. For instance, the reduction of the water allowance has to be collectively shared and a better performance of the network is expected if everyone uses drip irrigation. 


\subsection{Management changes and adaptation to drip irrigation technologies}

When an existing technology is embedded into a new context, an intricate process of socio-technical integration occurs. In this sense, technology is not understood as hardware with taken-for-granted outputs but it is accommodated in a social context. Both the context and the technology influence each other. Hence, roles and implications of the technology itself are not established but are modified according to the context and requirements of the users (Benouniche et al., 2014b; Garb and Friedlander, 2014). In this sense, this section analyzes the process of drip irrigation adoption paying attention to irrigation management (and the adaptation and appropriation of the technology), WUAs and farmers involved, as well as institutional arrangements that shape the context of technology adoption.

\subsubsection{Changes in the organization: centralization in water management}

The ARJ started implementing drip irrigation in 2000, and continues to do so now. Currently, the pressurized conveyance network is concluded and replaces the openchannel to deliver water. However, this channel is still in use to transport water for rice cropping from April to September. At present, drip irrigation serves an area of 4,482 ha, $30 \%$ of the 15,000 ha included in the drip irrigation project. Additionally, for 1,473 ha (10\%), the works were already finished in 2011, although the start of the drip irrigation service has not yet occurred due to the financial problems of the regional government and their delay in the payment to the construction company.

The Governing Board of the ARJ has guided and promoted the drip irrigation implementation process. After the design of the pressurized irrigation network, the new drip-irrigation sectors do not follow the structure of the previously existing local governing boards. By contrast, drip irrigation sectors are managed by the ARJ. This fact poses the question of what the functions of local governing boards will be in the future. In the case of surface irrigation, they had the responsibility of irrigation management at local level, maintenance of the network in the municipality, and calling the irrigation jury when required to solve existing conflicts. The result is an intended centralization of tasks in the central Governing Board.

In the case of the JTC, when the channel started the service in the beginning of 1980s, the system overlapped in some areas with the previous groundwater users. In these previously existing GUAs, farmers acquired water rights buying shares of the 
association. Water rights were proportional to entitled shares (equivalent to irrigation hours). Besides, GUAs management was conducted by the farmer shareholders belonging to the association, which have their own governing boards (Martínez, 2006). Hence, the JTC assimilated the previous groundwater irrigated areas, complementing them with surface water, although the associations remained independent, keeping their statutes and providing water in case of scarcity. This integration process occurred gradually in all the groundwater-irrigated areas with the development of irrigation from the JTC during the 1990s, consolidating this irrigated area.

In 1996, the regional government approved the works for the irrigation 'modernization' of the irrigated area, consisting of regulation ponds, pumping infrastructure, irrigation networks and a part for improvement and management. In 2008, drip irrigation implementation was concluded in $15,295 \mathrm{ha}$ (61.3\% of the area).

In the case of the JTC, drip irrigation implementation has prompted the merging process of WUAs managing surface water and GUAs. As described by the farmers interviewed in the area, in order to be able to use the new drip irrigation network, farmers had to pay an economic contribution. In addition, they had to agree to cede to the WUA shares from the GUAs they belonged to. This was done as follows: in order to compare or 'value' the different shares, the shares of each association were assigned a value in hours (e.g. the higher the flow available the higher the value in hours of the corresponding shares). Hence, farmers had to cede an amount of shares equivalent to 2 hours per hectare owned. The amount of shares depended on the GUAs they came from. As a result of this process of share ceding to WUAs, the WUAs became important shareholders in many GUAs.

Due to the fact of having a new water source and irrigation network available there was less interest in becoming a member of a GUA. In this sense, anyone who wanted to shift to drip irrigation could easily acquire the shares needed to join the WUA and use drip irrigation. With drip irrigation implementation, some GUAs were connected to the new distribution network built for drip irrigation.

In this context, there has been a change in management scale and centralization in the management of surface and groundwater. One of the interviewees mentioned that before there were small GUAs (managed by farmers) and now in many GUAs the control of water is an oligarchy. The WUAs have shares from GUAs; these shares are equivalent to water rights that they use when they do not have enough surface water 
from the JTC.

In the case of the WUAs of Vall d'Uixó, the process of drip irrigation implementation triggered the merging of the existing groundwater associations and the rationalization of the irrigation network. Before drip irrigation implementation, 19 WUAs supplied water to their members. Moreover, energy costs and water salinity were increasing due to aquifer depletion. In this context, farmers decided to shift to drip irrigation. The implementation of drip irrigation, with a new irrigation network to be designed, entailed important institutional changes. As a result, the number of associations dropped from 19 down to 12 and the new network followed a spatial criterion for water distribution, improving water use efficiency and stopping the use of water from the saltiest wells (García-Mollá et al., 2013).

\subsubsection{Changes in irrigation and fertigation management}

\subsubsection{Irrigation management}

Before drip irrigation implementation, in most cases the WUAs studied used a similar method for surface gravity irrigation: when water was going to be available in an area, farmers made requests to irrigate to the WUA, or sometimes to the person in charge of conducting irrigation (the regador). Then water was provided to the different plots following an upstream to downstream order and skipping the ones that had not asked for it (a turno system).

In addition, some measures were in place to improve efficiency on the canal network. These measures consisted mainly of works to improve the channels and the irrigation system in general (one WUA of the JTC even 'subsidized' with its own resources the investment in channel infrastructure to farmers). Besides this, other management measures and irrigation rules were adopted at plot level in water scarcity situations. Namely, during a drought, farmers were required to follow water-conservation rules on a regular basis. These rules consisted of using furrows to irrigate, having the plots properly leveled and having the canals clean and well maintained. In addition, they implemented a turno system in places where they commonly use on-demand irrigation, or a more strict application of the turno in areas where a turno system is already in place. The importance of looking at irrigation system performance and farmers behavior in situations of water supply constraints has been shown to be important in order to understand and assess water use over time (Soto-García et al., 2013b; Venot et al., 2010). 
In the majority of cases, for drip irrigation, the WUA sets a turn of irrigation for the different areas and crops, the irrigation schedule is set according to crop water requirements. Managing a fully automatized drip irrigation network of medium-large scale has the added complexity of properly integrating local conditions. Concerning the management of irrigation, it should be noted that in cases where a high level of automation exists in the network, decisions are mainly the responsibility of the WUA. By contrast, when an irrigation system is not completely automatic, farmers can make decisions about irrigation scheduling.

For instance, in a the JTC, there were three different coexisting systems: some areas where the WUA sets the irrigation schedule, other where the WUA sets a range of hours during daytime when farmers can irrigate if they open their valves manually, and other areas where they can irrigate whenever they want as the network works by gravity. In the cases when the WUA sets the schedule, some farmers mentioned sometimes asking the WUA for more irrigation time. For instance, in the case of the ARJ, modifying the schedule (increasing, reducing or stopping irrigation) represented around $70 \%$ of total reported problems.

It was also noted that farmers preferred irrigation turns that take place during the daytime, in order to be able to check irrigation performance, pressure and the clogging of filters and emitters.

From the point of view of water conservation, some contradictions were observed. For instance, one technician in charge of irrigation scheduling mentioned practicing 'psychological' irrigation. This particular practice was defined by the technician as irrigating more than crop water needs or earlier in the season. This practice was explained by the fact that, by doing so, the WUA avoids attending a significant number of complaints from farmers, personally or by phone. This seems to be a response to adapting to the logic of farmers to prefer, in some cases, the hydric comfort of the plant; a strategy that has also been observed by Benouniche et al. (2014a) in farmers in Morocco.

An unexpected effect of drip irrigation has been its susceptibility to robbery and vandalism. Furthermore, vandalism appeared to be of significant importance on a study conducted on 23 WUAs using drip irrigation in the Valencian Region. When technicians of the WUAs were questioned about the main technical problems found in water hydrants, 18 out of 59 reported incidences were related to robbery (solar panels, 
water meters, doors, and caps of equipment) (Miranda Ivars, 2011).

The interviewed members of the ARJ also mentioned the robbery of anything that is possible to sell as scrap metal as a significant problem, especially water meters (250 meters were stolen in one night, and approximately 2000 during 2012). The estimated cost of stolen equipment in 2012 was $€ 243,712$. In addition, vandalism is causing additional maintenance costs (repositioning, denouncements, vigilance, etc.). The problem is especially serious in areas where works have been finished but the drip irrigation service has not yet started. The existing solutions consist mainly of substituting metal equipment for other materials when possible, and disassembling some pieces to keep them in a storehouse until the beginning of the service.

\subsubsection{Duplicity of irrigation systems}

As previously mentioned (section 3.1), water conservation seems to be an important reason for the irrigation managers interviewed. However, this contrasts with the perception of the farmers interviewed who did not mentioned it as the main reason.

Moreover, during the interview, at least $10 \%$ of farmers mentioned conducting both drip and furrow irrigation (in areas where both systems were still in place). One of the farmers did this only during the first year of drip irrigation use, as an adaptation period, but the remaining farmers do so on a regular basis (once a month during the most water-demanding period, in July and August and, depending on the weather, they may also irrigate in June and September). Furthermore, one of the farmers mentioned doing this in order to perform tillage.

In addition, during the summer of 2012 (a dry year) the ARJ decided to conduct gravity-irrigation in a whole sector because, with drip irrigation alone, they had problems fulfilling irrigation water requirements. In order to do so, the WUA assumed the task of cleaning the channels needed to conduct surface irrigation once again.

The duplicity of irrigation systems is in place where farmers have not fully adopted drip irrigation, as in the ARJ and the JTC. The maintenance of both systems poses the dilemma of increased costs due to cleaning and maintenance of channels (usually once or twice a year). However, the abandonment and disuse of this existing infrastructure has also some negative effects. Some farmers mentioned they want the gravity system to be maintained, as a backup and because it is an investment that has already been made. Additionally, in the case of traditional irrigation systems, the 
network of channels usually has the function of drainage and water alleviation in case of heavy rains. Hence, the channels play the role of flood prevention in some of the neighboring villages.

\subsubsection{Fertigation management}

Concerning fertilization management, $63 \%$ of the farmers stated that they complemented the fertigation provided by the WUA by using venturi or other injection methods (by contrast, $37 \%$ of the farmers mentioned that the WUA made the decisions on its application and scheduling). This additional fertilization at field level may reduce the positive effect of reduced pollution highlighted by several authors (Cameira et al., 2014; Janat, 2008, 2007; Lecina et al., 2010a, 2010b; Oppong Danso et al., 2015).

Fertilization was one of the most conflictive issues from the perspective of farmers. On the one hand, the main reasons for disliking how fertilization is managed at WUA level were related to the lack of power farmers have in decisions on this issue. They also mentioned the lack of information on the amount and timing of fertilization applied. In addition, some farmers believe it is important to adjust the fertilizer dosage to the different existing crop varieties (although this may be technically difficult to achieve).

On the other hand, some farmers perceive collective irrigation only has to fulfill base fertilization (in this way they can decide on additional fertilizer expenses by themselves, and not incur costs they may not recover). In contrast with the opinions of smallholders in the area, one farmer who manages around 10 hectares of citrus (12 different plots) highlighted that he had difficulties controlling fertilization at every plot and he would prefer the WUA to add more fertilizers, which would also reduce his costs.

In addition, centrally managed fertigation seems to be a problem for organic farmers. In the case of the ARJ the solution has been to include them in turns without fertilization. However, it is technically difficult to guarantee them an absence of fertilization, which is necessary for labeling requirements.

Improved management of fertilization seems to be complex to deal with at WUA level due to the different expectations farmers have. The need to decide on fertigation and to adjust it to different varieties, together with a lack of confidence or transparency, seem to explain the high percentage of farmers adding fertilization at field level. 


\subsubsection{Changes in irrigation rules}

Despite the technological changes, none of the interviewed WUAs has modified its bylaws, and have yet to adapt them to the new irrigation method. However, new rules have been implemented. In the case of Vall d'Uixó, they set a maximum water use per day, over this threshold the valves are automatically closed at field level. A farmer from the JTC mentioned that the WUA provides them with more water than needed, and farmers adjust water use by closing their valves at field level. In another WUA there is a limit of volume use, and above this the price is higher.

In addition, the ARJ has also a flow rate limit allowed per plot. In order to meet this, they established technical guidelines to be followed (the use of self-compensating emitters, emitter flow rate, separation between emitters, filters, valves, etc.). This is checked by the WUA before admission to drip irrigation is registered and made effective.

One member of the management board of the ARJ stated that they are starting to work on the modification of the bylaws although "it is much more difficult to change the bylaws than to shift to drip irrigation" because it is where the quotas of decision power for the different irrigated areas are established.

\subsubsection{Changes in the structure of the staff and training for farmers}

Concerning labor force structure, modernization requires shifting from low qualified to technical staff. In this sense, new types of labor related to new irrigation technologies and management (automatisms, computerization, remote control, etc.) are generated (GilMeseguer, 2010). In all cases, the structure of the staff in the WUAs has changed with drip irrigation. The number of technicians has increased and some of the interviewed WUAs now employ one or several technicians to deal with irrigation scheduling and management. In cases where no technicians are hired, one person from the management board has assumed these functions. By contrast, the number of people in charge of conducting irrigation (regador) has significantly decreased in a range between $40 \%$ and $100 \%$. The number of administrative workers has remained the same in most cases.

WUAs also assume the maintenance of the drip irrigation network, except in the cases of Vall d'Uixó and in the ARJ (for the conveyance network and irrigation stations), where they opt to hire a company. The maintenance of the network is important to guarantee its proper operation and to avoid and prevent future problems. Currently, there is a predominance of corrective rather than preventive maintenance. In addition, 
the remote control system provides a great deal of information that has to be managed and prioritized. Quality assurance, action protocols, and system optimization appear to be the new challenges for WUAs in order to improve water management. SotoGarcía et al. (2013b) have shown the scope and advantages of improvements in this direction (early warning of vandalism, equitable and transparent water management, ITCs services, etc.).

From the point of view of water distribution, drip irrigation projects seem to reduce the importance of the role of farmers at plot level. However, in order to have a result of effective water management, plans to implement new technologies should also include training for farmers and capacity building programs and, above all, orientation about adequate crops and measures to industrialize and commercialize them (Gil Meseguer, 2010). This is a key issue to promote adoption of new irrigation technologies but also to promote best management at plot level. Best management requires trained farmers that are familiar with new technologies. In the area studied, $54 \%$ of the farmers stated that they had received some training. However, only 37\% mentioned having received any handbook or information on best practices for drip irrigation management.

\subsection{The perceptions of farmers and their satisfaction with drip irrigation}

When looking at the reasons for finding drip irrigation more convenient, several advantages were mentioned: there is no need to be in the field to irrigate, they avoid the task of adding fertilizer when conducting gravity irrigation. Furthermore, they avoid having to ask for the water turn and looking after and paying the irrigator (in some WUAs surface irrigation is always conducted by an employee of the WUA, in other cases farmers delegate this task to a third person they hire by the hour, whereas in others irrigation is conducted by the farmer). Some farmers mentioned that, with drip irrigation, they avoid having to argue with anyone else to get the water, as the process is automatic.

They also mentioned drip irrigation is easier to control, and that they do not have to worry about irrigation, as it only requires checking the state of the system regularly (once or twice a year). This contrasted with the opinion of other farmers that mentioned that this convenience should be put into context, because the drippers and filters get clogged, pipes need to be regularly substituted, and regular checking of the system is important (these farmers mentioned checking the system every 3 to 5 days). 
The latter farmers mentioned that, with surface irrigation, there is only a need to look after irrigation once every 3 to 4 weeks during spring and summer (in the case of citrus) and to perform the tillage. In addition, it was noted that drip irrigation reduces other farming tasks, mainly weed removal and tillage. Having a higher uniformity in irrigation or more confidence on the expert decision for irrigation and fertilizer application were also mentioned as advantages of drip irrigation.

When farmers were asked about their general satisfaction with drip irrigation in comparison with surface irrigation, $67.1 \%$ answered it was better, $15.7 \%$ claimed to be less satisfied and $15.7 \%$ stated it was the same (3\% of them did not answer this question).

\subsection{Conclusion}

Drip irrigation has been promoted as a widespread solution to reduce water consumption. In our attempt to study changes occurring with drip irrigation implementation in three case studies, we aimed to understand and explain how these technologies are used and adapted. Our analysis suggests that drip irrigation facilitates the integration of infrastructures and centralization of management. The WUAs have taken drip irrigation implementation as an opportunity to centralize management (irrigation tasks and water sources). However, they provide some flexibility to farmers (to modify the irrigation schedule, to add fertigation at plot level, etc.). Drip irrigation seems to have had a positive impact on the comfort of farmers, reducing some farming and irrigation tasks, and, in general, most farmers are satisfied with drip irrigation. Nevertheless, the tradeoff has been a reduction in the power of decision for farmers, resulting in fewer actors involved on water management, and less irrigation decisions taken at local level.

The technological change entailed a process of adaptation of irrigation rules (even though it is not reflected in their bylaws), institutions and irrigation management. In this process, WUAs and farmers have encountered difficulties and unexpected effects (higher fertigation, water use and vandalism). In order to face the complexity of irrigation management and how it is adapted to different contexts, irrigation policies aiming at new technology implementation may benefit from a wider understanding and focus on farmers, how they are affected by the new technologies and how they adapt to irrigation changes. 


\section{General Discussion of Results}

Irrigation and water policy have been evolving in the past decades in order to respond to the existing challenges: agricultural intensification, increasing competition on water resources, environmental concerns and sustainability. Initially, water resources management approaches were dominated by a technical approach focused on technical and end-of-the-pipe solutions, such as the improvement and development of water and irrigation infrastructure. In addition, concepts related to water policy have been shaping and steering the debates around water management in the past decades: integrated water resources management (IWRM), water governance, irrigation management transfers, public participation, and more recently adaptive water management and water-foodenergy nexus. In many cases, policy measures such as state management, farmer's management or water markets have been recommended as straightforward solutions without testing their results. However, environmental management problems are complex and cross-cutting. Hence, tackling them requires the integration of insights from natural and social sciences in order to produce relevant knowledge (Pahl-Wostl et al., 2013). In addition, contextual factors and water users are important to achieve expected results. Therefore, it is widely acknowledged the need to avoid applying panaceas in water management (Meinzen-Dick, 2007; Ostrom, 2007; Pahl-Wostl et al., 2012).

In different parts of the world there exist irrigation systems that have operated for hundreds of years developing flexibility and resilience to adapt to disturbances. In such systems, the intricate relations between farmers and the environment play an important role in adapting to local environmental variability. Hence, understanding the functioning of these systems can be useful to identify conditions contributing to successful collective-action over time. These cases offer a range of governance and management models were irrigation performance has been sustainable, robust and effective over long periods. 
In this thesis several aspects of irrigation management have been considered:

- Governance and operation of irrigation systems

- Integration of water sources

- Changes occurred with drip irrigation implementation

- $\quad$ Farmer's and WUAs manager's perceptions

These aspects are relevant and need to be considered in order to promote effective irrigation policies and also in order to evaluate them. These aspects are transdisciplinary and include both social and technical implications, which are related and interact, changing and evolving over time. In this sense the results presented in this thesis provide new insights, contributing to the improvement of decision-making related to irrigation policy and management.

In relation to that, this chapter presents, in first place, a discussion related to the use of the Trawick's theoretical model and the integration of new water resources (section 5.1). Afterwards, section 5.2 analyses in more detail the changes occurred with the implementation of drip irrigation. This is followed by an analysis of some crosscutting aspects related to the changes occurred with the adoption and adaptation of both new technologies and water resources (section 5.3). In this sense, selected aspects of governance and management are analysed for the studied traditional irrigation systems. Besides, a comparison of the influence of the processes of change occurred with the integration of new water resources and drip irrigation is provided. Lastly, section 5.4 considers the issue of robustness and sustainability of irrigation systems in relation to the studied cases.

\subsection{Trawick's theoretical model and the integration of different water resources}

It has been widely argued, that research-informed suggestions to improve natural resources management need to be adapted to the context into which they are embedded (Ostrom, 2007; Thiel et al., 2015). Therefore, prediction of outcomes, behaviours and explanations requires to be built in careful and sound studies. Yet, the consideration of every case as unique, due to its complexity and specificity may also make more difficult to devise a path towards more general policy recommendations. Thus, models and frameworks provide a ground for the examination of commonalities and differences 
between irrigation systems, although the challenge is to recognize the specificities of the context (Thiel et al., 2015).

Using Trawick's model (2008, 2001a), we have explored a range of operating principles that affect the degree of success of institutional rules to reinforce collective action in traditional WUAs in Valencia. These features do not take into account the general cultural, political and socio-economic conditions. Though, relations with other stakeholders and state organizations are relevant in framing the context where water management and governance takes place (Saravanan, 2015). Thus, these concerns motivate to further study these relations, especially in water scarcity situations, were coordination, negotiation and cooperation between water users and administrations seems to be important.

The principle of boundary maintenance, proposed by Trawick $(2008,2001 \mathrm{a})$, based in Ostrom's (1990) design principles, has been debated in the light of historical studies (Garrido, 2012, 2011). In a system where water rights are tied to land, irrigation expansion would imply the reduction of the irrigation frequency (when using contiguous irrigation), posing a social dilemma. However, we are aware that processes of unsustainable expansion of irrigated lands have occurred in many WUAs in eastern Spain (Garrido, 2011). Furthermore, the system is based on the existence of lands with priority rights (permanently irrigated lands in Table1.1) and lands with rights to surplus water only (extremales in Table1.1). This arrangement provides the possibility to adapt water management to the irregularity of Mediterranean rivers, and to control the impact of drought by ensuring a minimum quantity of water needed for the viability of crops (Garrido, 2012; Sales-Martínez et al., 2014).

In addition, in an initial phase of the study of drip irrigation cases, we used some concepts of this theoretical model to study farmer's perceptions about the changes occurred with drip irrigation implementation. This proved to be fairly difficult, probably because it involves a drastic change in operation and irrigation management, and because the operating principles proposed in Trawick's model $(2008,2001 \mathrm{~b})$ are based in gravity irrigation.

The theoretical operating principles proposed by Trawick are more general and abstract than the irrigation methods, in practice. Nevertheless, the use of the theoretical model has proved useful to deepen in the understanding of farmer's perceptions and working rules. This model has allowed us to develop and empirically test relationships 
between different aspects that support cooperation in irrigation management. In addition, it was useful to focus the attention, narrow-down and assess critical sociotechnical characteristics of collective irrigation management. In this respect, future research addressing the application of these principles to analyse self-governance of irrigation could be especially pertinent.

The irrigation system of the Huerta of Valencia has adopted groundwater and treated wastewater as new water resources. The contribution of our approach can be identified as the analysis of how self-governed water management institutions have been adapted to integrate these new resources. Especially given the limited literature exploring the conjunctive use of surface, groundwater and treated wastewater. In addition, this has helped to figure out how cooperation among GUAs and surface water WUAs takes place.

Moreover, groundwater and treated wastewater were used intensively in periods of severe drought. The use of additional resources has not produced any major conflict. However, from the point of view of collective use, the use of new resources as supplementary resources, or the introduction of new water resources upstream in the system, seems to contribute to a more equitable water distribution (as it respects the uniformity in irrigation frequency). It is important to consider that differences in irrigation frequencies between different areas or WUAs may be perceived as unfair. In addition, the availability of new water sources also implies a lower dependency in surface water. This aspect, may also contribute to the prevailing low level of free-riding.

Even though the lack of consensus on defining conjunctive use, our analysis suggest conjunctive use is applied to some extent in the Huerta of Valencia. The conjunctive use of surface water, treated wastewater and Drought Emergency Wells seems to conform more to the definitions of conjunctive management. In the sense that these resources are used in a coordinated and integrated way, responding to the concept of management at system or basin level. This is due to two reasons, firstly, because the same organization, the WUA, is in charge of its management and distribution. Secondly, because the use of these resources, in exchange for surface water flows, was negotiated with the JDWA during the 2005-2008 drought period. However, the role of GUAs in conjunctive management of surface water and groundwater responds more to a decentralized approach to adapt to drought.

In the cases studied in the Huerta of Valencia, the use of groundwater is limited 
to moments of higher scarcity. Farmers in GUAs share well ownership, operating costs and an initial investment. Similarly, GUAs could not distribute water without using WUA's system of channels. As a result, groundwater use restriction is linked to surface water availability and infrastructure. As noted by Rica et al (2012), sharing a common infrastructure and the need for group investment (not affordable individually) are relevant factors for cooperation in groundwater management.

In addition, the sharing of infrastructure between GUAs and WUAs is also a factor favouring cooperation. For instance, several interviewees argued that water from GUAs can be fed into the surface water system of channels, and mentioned this has been done in cases of severe drought. In addition, one WUA was found to contribute generously to cover the costs of GUAs located within their service area. This was seen as a measure to avoid abandonment of groundwater infrastructure, helping GUAs to cover the fix costs, especially during wet periods when groundwater use is low (and therefore, users do not pay for its use). The overlap of farmers, irrigated lands and infrastructure creates a situation of conjunctive use and cooperation between the different organizations.

Although this interactions occur informally, this type of spontaneous use or "in lieu" groundwater recharge appears to be an effective water management strategy, contributing to aquifer replenishment during wet years and using groundwater more intensively (and at a higher cost) during periods of scarcity, contributing to maintain a long-term balance. It should be noted, though, that water use expansion is limited, as the neighbouring agricultural areas are also irrigated. Kuper et al. (2012) have shown that in the Tadla surface irrigation system (Morocco), where surface water is used at a lower cost, access to groundwater has also provided buffer capacity for periods of scarcity. In addition, informal conjunctive use has resulted in diversification of cropping patterns and intensification of agricultural production (e.g. implementation of drip irrigation). However, it has also resulted in exclusion of small-scale farmers from groundwater. In the case of Valencia, although this last subject would require further study, the interviewed farmers (in areas where both resources are available) mentioned that exclusion was low and that water would be shared in case of scarcity.

Many irrigation systems operate in a conjunctive use context where both surface and groundwater are available, and often interconnected. Conjunctive use provides flexibility for farmers and it also provides operational flexibility for water managers and authorities (Pulido-Velazquez et al., 2004). In the case of the Huerta 
of Valencia, the existing institutional arrangements, comprising different organizations (WUAs and GUAs), limit a more integrated conjunctive management ${ }^{17}$. One of the reasons seems to be that by assuming the management of those wells WUAs may risk their collective water rights. In case they assume the management of a communal well, the Júcar District Water Authority may review their water allowance from river water in compensation for the water provided by the new water source. This policy, which seems logical from an administrative point of view, hinders, in practice, the more integrated use that would possibly take place if both sources would be conjunctively managed. In addition, the current situation of groundwater use and licensing would be easier to control by the administration than with the existing high number of GUAs. Additionally, the operation and maintenance costs could be equally shared among the members of the WUAs. Meanwhile, in the areas where groundwater use is minimal in ordinary conditions, it could continue allowing for the flexibility sometimes required by the schedule or by crop water needs.

\subsection{Changes occurred with drip irrigation technologies}

The upgrading of irrigation infrastructure, mainly the implementation of drip irrigation, has been, and continues to be, one of the most often-sought water policy measures to improve irrigation efficiency. Therefore, the literature focusing on institutional, water governance and management changes related to drip irrigation implementation has increased in the past five years. However, when looking especially at collective drip irrigation implementation the number of existing works we are aware of narrows down significantly. Our contribution explored this subject and revealed interesting insights about how this process led to an adaptation and use of the technology at farmer's and WUA's levels. Because of the limitations of the research design and method, our analysis focussed specifically on local collective management and did not tackle in a detailed manner farmer's daily practices, typologies, multi-level interactions and dynamics induced by power relations and cultural factors.

In the studied cases, WUAs had to take the initiative and decide to shift to drip irrigation, and then participate (at least moderately) in the design and implementation process. The role given to WUAs seems to have allowed for a better transition and

17. For instance, as it occurs with Drought Emergency Wells or in the case of the well managed by WUA of Tormos. 
acceptance than in other circumstances where it has been imposed by the administration. This contrasts with other cases, where the implementation of technological solutions has been directly conducted by the administration, treating irrigators as passive recipients or benefactors. For example, the case of implementation of automatic sluice gates in Australia in order to save water, causing significant management short-comings and important farmer's discomfort (Collett and Henry, 2014). In Seguia Khrichfa (Morocco), the implementation of circular orifices as off-takes at the bottom of the channels in a State rehabilitation project, resulted in farmers not using or destroying them. These orifices had implications on water disputes, as water delivery was more difficult to control and some farmers enlarged them, resulting in problems of lack of transparency (van der Kooij et al., 2015).

It has been stressed that it is essential for policy interventions, especially regarding natural resources management, to study and record unexpected effects (Ostrom, 2007). In addition, any technology implementation project dealing with water conservation needs also to proceed with caution as unintended impacts are possible (Collett and Henry, 2014). Due to the complexity of resource systems, and the inability to predict unintended effects accurately for different contexts, negative unforeseen impacts have to be considered for each case. Incorporating conditions to deal with them at multiple scales in policy implementation strategies is necessary to evaluate them in light of real results and to improve the knowledge about policy consequences (Salazar, 2014).

Regarding new irrigation technologies, technical unexpected effects may include communication breakdown in automatisms and measurement inaccuracies (Collett and Henry, 2014), two aspects that have also been mentioned by the WUAs managers interviewed. In addition, we have also noticed duplicity of irrigation and fertigation. Moreover, irrigation costs after drip irrigation implementation show some degree of uncertainty. This is due to the fact that factors such us the origin of the water sources, the decrease in water consumption achieved, energy use efficiency and energy cost play an important role (García-Mollá et al., 2014).

Another unexpected effect of new irrigation technologies includes the loss or deterioration of material and immaterial heritage. The implementation of drip irrigation often results in disuse leading to the abandonment or disappearing of channel irrigation networks (Sese-Minguez, 2012). The damage and loss of water heritage is not often considered in the decision making process of implementing piped irrigation networks 
(Sanchis-Ibor et al., 2016). In addition, water immaterial cultural heritage linked to gravity-fed irrigation is valuable and rich in traditional irrigation systems.

Paradoxically, policies promoting a collective shift to drip irrigation appear to favour the loss of water material and immaterial heritage. However, institutions and customary rights, knowledge and expertise to respond to local constraints, have demonstrated to be sustainable, even under extreme environmental conditions (Ftaïta, 2010). Therefore, drip irrigation may have a disruptive effect in irrigation organization as institutional arrangements for community management have traditionally been linked to gravity irrigation.

We have also mentioned one case when it was not technically possible to fulfil irrigation water requirements during a dry year. Hence, complementary gravityirrigation was performed at WUA level. In the future, this may not be easily done if the channel network becomes damaged. These considerations show that collective drip irrigation management is complex and requires good knowledge of the system over long periods.

Therefore, drip irrigation implementation draws attention to the evaluation of technological use and institutional arrangements and how they co-shape each other (van der Kooij et al., 2015), beyond performance and user satisfaction. Hence, paying attention to complex relations among stakeholders and their motivations, and recognizing the human and social dimension of technological innovation, may be useful to support the transitions involved and avoid failure and drawbacks in policy implementation.

\subsection{Adoption and adaptation of new resources and technologies}

Both the introduction of new water sources and drip irrigation technologies entail changes in governance and management of water resources. From the theoretical point of view it is relevant to go further than the state - irrigators dichotomy in the analysis of governance. For instance, looking at centralization and technocratization of management (Palerm-Viqueira, 2009). The different cases of famers-management give insights in relation to the debates about management models based on 'local' or 'technical' knowledge. 


\subsubsection{Irrigation management and governance in the traditional Water User} Associations of the Huerta of Valencia and the Acequia Real del Júcar (ARJ)

The long-lasting irrigation systems studied (the Huerta of Valencia and the ARJ) have a governance and management model consisting of different levels of farmer's representatives and hired workers, which seem to be necessary due to the mediumscale and complexity of these irrigation systems (Palerm-Viqueira, 2009). According to Palerm-Viqueira (2009) the cases of the ARJ and the WUAs in the Huerta of Valencia, including the Real Acequia de Moncada and La Vega (the nine WUAs comprising the Water Tribunal), correspond to a case where the authority is centralized. In both cases a governing body, including representatives of the different irrigated areas, is in charge of decision-making. However, in the case of the ARJ there are also local governing bodies.

In contrast, the studied GUAs in the Huerta of Valencia are smaller in scale than the studied WUAs. In some of the studied GUAs we found a person in charge of actioning the pump and sometimes also in charge of distributing water (known as motorista) (Table 5.1). In other cases, the pump is actioned by irrigators themselves by means of special-purpose coins. In these cases, all irrigation tasks are conducted by the irrigators.

From the point of view of irrigation management, the studied traditional irrigation systems present differences regarding the tasks conducted by hired staff and farmers regarding water distribution and infrastructure maintenance. In the case of the Real Acequia de Moncada and La Vega there are water officials in charge of distributing water to the different irrigated areas. By contrast, deriving water until the plot and irrigation at field level is conducted by farmers themselves. However, in the case of the Real Acequia de Moncada farmers may have the possibility, in some areas, to hire this task to a regador (in this case, the hired irrigator is not an employee of the WUA). In addition, meanwhile the maintenance of main channels is conducted by the water officials, every farmer has to clean the channels limiting with his field. In this sense, irrigation tasks are more decentralized than governance, as management tasks are divided between farmers and staff of WUAs (Table 5.1).

In the case of the ARJ, the local governing boards of the WUA have employees in charge of distributing water at village level and conducting gravity irrigation at field level. Similarly, the cleaning of the secondary channels is also assumed by the local governing boards. In this sense, the management arrangements in the ARJ can 
be considered more dependent on hired staff than in the Huerta of Valencia, because farmers do not participate in tasks related to irrigation management (even though they decide whether to irrigate or not within the turn). In addition, this system seems to be more decentralized in the sense that management tasks are divided between staff hired by the governing board and the local governing boards (Table 5.1).

\subsubsection{Comparison of changes related to the adoption of new technologies and water resources}

If we look at the introduction of groundwater (from Drought Emergency Wells) and treated wastewater, this process has not entailed major changes in water management and governance in the WUAs of the Huerta of Valencia. However, groundwater use expansion (in the traditional system based in surface water) was articulated by means of devising a new type of associations (GUAs). In this way it was possible to have access to a new water resource but the management remained the responsibility of the governing bodies of GUAs. Therefore, WUAs managers and users have gradually adapted management practices dealing with the challenges of integrating new resources. In this sense, new rules have been crafted and are applied to manage the use of different water resources and some informal coordination appears to exist.

By contrast, drip irrigation implementation involved an important technological transformation. This process entailed a fundamental change in the management of water in the studied cases, leading to a more centralized management. Although its positive impact regarding comfort and reduction of farming tasks, the trade-off is in some cases a reduced decision-making power at farmers level. We can also add that, in the case of the ARJ, there has been a technocratization of management. For instance, when using gravity irrigation, the Acequiero Mayor (trained on the job) is the person in charge of water distribution between the different villages. In addition, farmers decide when to irrigate. By contrast, with drip irrigation WUA's engineers decide how irrigation is managed, applying technical and agronomic criteria for water distribution and scheduling. However, in other studied WUAs (of smaller scale than the ARJ) drip irrigation scheduling is conducted by a member of the association, sometimes after an initial training or with advice.

Regarding the implementation of drip irrigation, it should be noted that in the theory of the commons technology does not play an important role in analysing how the 


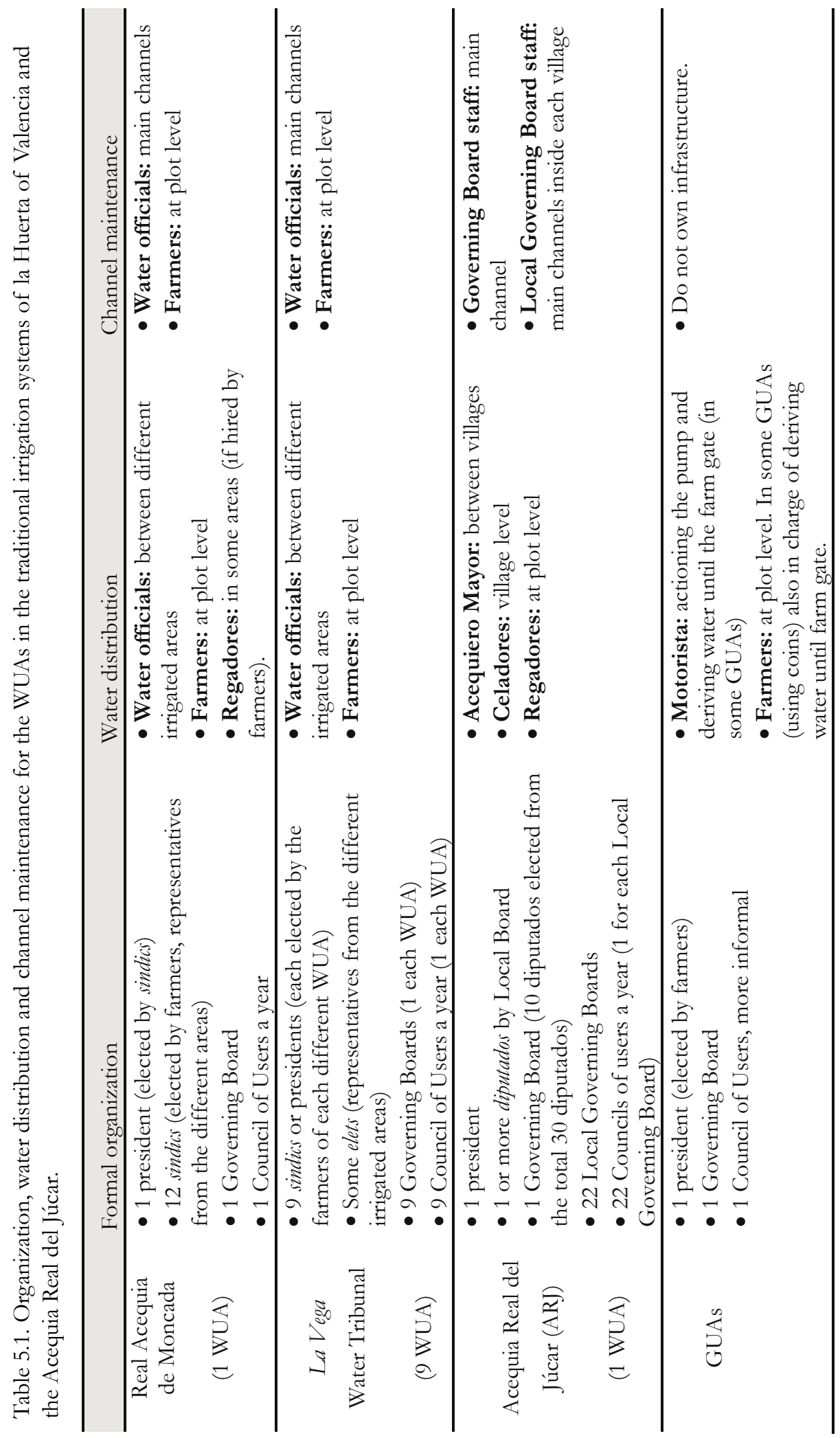


system works. Technology is rather understood as a contextual variable that affects the social and institutional context. Hence, it is an open question if irrigation technologies have an impact on robustness to drought and whether or not technological changes may increase or reduce incentives to cooperate (Poteete et al., 2011; Villamayor-Tomas, 2014). Here we have seen that community institutions and customary rights are not an obstacle for the implementation of new technologies, although drip irrigation implementation entails important changes regarding operating rules. In collective systems users interact and are affected by system features. As a result, such transformation processes will have winners and losers. Therefore, changes in the structure and institutions affect the distribution of risks and returns (Anderies and Janssen, 2011).

The implementation of drip irrigation aims at increasing efficiency using an agronomic approach, seeking to adjust water use to crop water needs. By contrast, as we have shown by looking at irrigation practices in moments of water scarcity, models based in local knowledge (or the 'moral economy') give more importance to water sharing agreements, especially in the moments when water becomes scarce. Although based in community management, the transformation to drip irrigation entails a shift from a system based on local knowledge to a system based in agronomic and technocratic management. However, satisfying crop water requirements in not necessarily a premise for effective governance. In this sense, the agronomic model seems to overlook the importance of arrangements covering broader concepts of water management.

As we have seen, the encounter of these two models results in important contradictions. Furthermore, the traditional irrigation practices challenge the dominant agronomic model guiding most of the irrigation management reforms in Spain and many other countries of the world. For instance, in the traditional systems studied here, the use of an irrigation turn with equal irrigation frequencies for the different users provides incentives to conserve water. By contrast, this type of feedback does not necessarily exist in drip irrigation schedules. However, the implications of the shift to drip irrigation are not so straightforward in practice. For instance, the use of pressure networks could result in a less transparent distribution. However, the interviewed farmers did not mentioned transparency problems with water, and seem to trust water distribution and metering, but they showed more concerns regarding fertilization management. Therefore, mechanisms providing transparency would be useful to avoid some collective management troubles. 
In order to bridge the divides between agronomic and water sharing considerations (and between water conservation policy objectives and farmer's aspirations) a shared vision of water management needs to be developed. This new perspective needs to include, combine and adapt characteristics of irrigation management prior to drip irrigation and new requirements linked to a new technology. For instance, including self-organization dilemmas: equitable sharing, transparent management, adaptation to drought and conflict resolution. However, the question of how collective drip irrigation systems will develop such a new perspective remains open.

Until now, approaches with a prominently technological focus seem to have hindered such processes. When farmers mentioned they have been obliged to convert to drip irrigation it seems that, even though drip irrigation implementation processes have been community driven (and accepted by the majority of the council of users), the transformation processes have not been based in extensive farmers participation nor subjected to intense debates regarding drip irrigation conversion and implementation. However, future research is required in order to elucidate more aspects of these transformation processes (decision-making, actor's participation, learning processes, etc.).

The studied cases have shown examples of how self-governed irrigation systems have integrated new water resources and adapted to the use of drip technologies. The integration of new water resources entailed the crafting of new rules and agreements for the coordination and use of these resources. In addition, new types of organization were devised for collective groundwater use. By contrast, drip implementation opens up the possibility to undertake major transformations in the organizations managing irrigation. These important transformations present new and important challenges for collective drip irrigation management. In order to address these challenges, in the future, water management policies need to include the broader aspects of water governance and a more contextualized understanding of water management.

\subsubsection{Other considerations regarding drip irrigation policy}

As a result of the fixation on the technological part of a technological intervention, social aspects are often overlooked. Therefore, less efforts are devoted to management aspects and social transition than to infrastructure development (Collett and Henry, 2014). For instance, although the Spanish National Irrigation Plan included 'support 
programmes' for training, follow up and evaluation, only $1 \%$ of the budget was assigned to these complementary actions meanwhile most efforts were devoted to infrastructural interventions (99\% of the public investment budget) (MAGRAMA, n.d., p. 443). Although the cost of infrastructural investment is usually higher than training measures, the plan seems to have underestimated the importance of management and social aspects in technology implementation.

Engineers, policy-makers and farmer's objectives may not coincide in statepromoted collective drip irrigation. Using an approach aimed at reflecting user's and manager's perspectives has proved useful to understand how irrigation systems work. In addition, it has shown how drip technology is used and what changes it has entailed. Irrigation performance at field level depends on the irrigation equipment, on irrigation practices and maintenance, but also on farmer's and WUAs manager's objectives and constraints. As ultimate users of irrigation technologies, farmers and WUAs are key actors in policy implementation. We have seen as examples the case of duplicity of irrigation systems or the 'psychological' irrigation practice. In addition, as shown by Benouniche et al. (2014a) in the Sais (Morocco), all studied farmers using drip irrigation were over-irrigating, and their motivations and practices where important to understand thier reason (and related to their different profiles). Therefore, an environment providing incentives for water conservation is also necessary in order to achieve the policy objectives (Vidal et al., 2001). Subsequently, to introduce technology as a way to ensure water 'savings' is a limited approach.

In addition, drip irrigation is not a panacea, nor the only technique that saves water (Vidal et al., 2001). The justification to transform traditional systems in drip irrigated ones is not straightforward and unequivocal (Luquet et al., 2005). Drip irrigation results may be excellent or poor. Water efficiency in drip irrigation may be similar to surface irrigation (or lower) when there is poor maintenance or farmers are not familiar with the technique (Benouniche et al., 2014a; Vidal et al., 2001). These considerations may be helpful to improve the scope of future irrigation policies.

In the WUAs of Campo de Cartagena, drip irrigation performance indicators were assessed during a 10-year period in order to understand farmer's strategies to adapt to water scarcity. Furthermore, performance indicators varied significantly over time, and water scarcity was the most important factor influencing them. Management improvements (automation, real-time monitoring, and online communication) had 
advantages such as reducing conflict, early warning of vandalism and providing more equitable and transparent water distribution (Soto-García et al., 2013a, 2013c).

New technology may create new expectations; its different characteristics imply advantages and solutions to existing problems but also new limitations. In addition, a technological shift implies a decision-making process, where underlying reasons to adopt technologies are also important to understand how technologies are used in practice. Both the use of new water sources and new irrigation technologies have entailed changes regarding water management and governance. Furthermore, how these technologies are implemented has implications for equity and water governance (Collett and Henry, 2014).

\subsection{Long-term sustainability of traditional systems}

The issue of long-term sustainability of traditional irrigation systems that have adapted to the existing social and ecological context has been the subject of many irrigation studies. The underlying assumption has been that the success of an institution is, to a certain extent, related to its prolonged existence. In these studies, concepts such as robustness, resilience and adaptive capacity have also played a role to assess the performance of irrigation management (Anderies et al., 2013, 2004; Costejà-Florensa, 2009; Cox and Ross, 2011; Dietz et al., 2003; Janssen et al., 2007). In many cases, institutions that have lasted for centuries have not been recognized or they have been dissolved. This was not the case of the Spanish legal context that provided a framework for these collective irrigation institutions to continue managing water resources, recognizing to some extent a model based on 'local' knowledge and farmer's management (Gimenez-Casalduero and Palerm-Viqueira, 2007).

The cases studied in this thesis show that collectively managed irrigation can be an effective way of managing water, integrating different water resources. The Huerta of Valencia, as an irrigation system lasting for centuries in a difficult environment, has been able to balance demand and supply through history developing robustness to drought. The studied WUAs have been able to devise rules and agreements and the existence of strong property rights facilitates cooperation among users. In addition, the integration of new water resources and water sharing agreements were useful to adapt to the reduction of water availability. In other traditional irrigation systems in New Mexico 
similar arrangements have been shown as well to contribute to provide robustness during water scarcity periods (Cox and Ross, 2011).

While the WUAs in the Huerta of Valencia have prevailed in an environment characterized by climate irregularity and recurrent droughts, other novel problems threaten nowadays the sustainability of these systems. Some of them include urbanization and city growth, pressure on natural resources and agrarian ecosystems, new water uses, decrease of agricultural profitability, feasibility of smallholder agriculture, land abandonment, ageing of the agricultural population and lack of generational relief (which influences the temporal horizon considered for decision-making).

Nevertheless, long-term sustainability does not imply the capacity to confront and adapt to these new circumstances (Costejà-Florensa, 2009). Furthermore, robustness is generally associated to fragility trade-offs. Systems with local robustness have interdependencies between farmers, infrastructure, institutions and the environment which are the result of past adaptation to local conditions. These interdependencies are associated to other fragilities that are often hidden, in the sense that they can be only revealed by system failure (Anderies et al., 2013; Anderies and Janssen, 2011). The transformation processes in the political, economic and social context have no precedents in speed and intensity. In addition, globalization increases the complexity of adapting to these uncertainties and disturbances, as changes occur at larger spatial scales and at multiple levels of organization (Anderies et al., 2013). These types of phenomena are not within the frontiers of previous similar situations where these irrigation systems are used to act, prevent, and soften the impact (Anderies and Janssen, 2011; Costejà-Florensa, 2009). However, this situation may lead to the erosion of institutional structure or to innovation, transforming its initial structure and developing new solutions that provide the possibility for the system to adapt (Costejà-Florensa, 2009).

Although it can be debated whether or not the material and immaterial heritage of these long-lasting systems constitutes an intrinsic value that deserves to be maintained (Cox and Ross, 2011), the knowledge and know-how in these systems has contributed to establish different models of collective-management. These models are not outdated as they establish an intricate connection between farmers and the environment, regulating 
and adapting management to the available resources and local constraints by means of customary rights (Ftaïta, 2010). The recession or disappearance of traditional irrigation may entail losing the opportunity to learn about irrigation practices and institutional arrangements for collective water management and governance (identifying its advantages or disadvantages) in comparison with other property right regimes (Cox and Ross, 2011). These aspects may be useful to address present water and environmental management challenges. 



\section{Conclusions}

This thesis deals with the effects of the integration of new water resources and drip irrigation implementation in community-managed irrigation systems. For this purpose, various features of technological use, integration of new water resources and their institutional arrangements were analysed in order to contribute to a better understanding of irrigation systems and adaptation to drought. In particular, paying attention to the organizations in charge of managing irrigation as well as farmer's perceptions. These aspects were examined by using theoretical models and comparing case studies.

The studied cases illustrate how self-governed irrigation systems have integrated new water resources and adapted to the use of drip technologies. The existing arrangements are crafted for context-specific settings, depending on the water resource, the technology, the actors, institutions and organizations. The analysed subjects encompassed the currently prevailing water policy measures in the Valencia region and at world level: drip irrigation implementation, reuse of treated wastewater and conjunctive use of surface and groundwater. Therefore, this thesis reflects on current water policy dilemmas.

In many places around the world irrigation systems originally supplied by surface water have increasingly developed the use of groundwater. This has led to an important decrease in water tables that is currently a major concern worldwide. In addition, another problem is the limited application of conjunctive use (Bouarfa and Kuper, 2012). Together with the development of groundwater use, new institutions (both formally and informally) have been developed locally, although informal institutions are not often recognized.

The integration of multiple resources is a strategy to increase water supply and to adapt to drought. The different resources available (surface water, groundwater and treated wastewater) differ in temporal availability, cost, quality and flexibility of use. These resources are complementary and therefore they need to be used in a coordinated way. Thus, collective institutions seeking additional resources such as groundwater or 
non-conventional resources (treated wastewater and desalinated water) need to develop and craft new rules accordingly.

As it happens in Mexico (González-Pérez et al., 2013), South Asia (Shah, 2007) or the North of Africa (Ftaïta, 2010), Spain has developed a wide experience of collective management. In order to tackle sustainable groundwater management and the integrated use of water resources, the analysis of groundwater, surface water and treated wastewater institutions, as well as formal and informal coordination, may contribute to find to new ways of water governance. The challenge is then how to draw some lessons from these local arrangements that could be able to contribute to policy-making.

In the studied cases in Valencia, groundwater organizations are formally recognized, however the arrangements dealing with their interaction are mostly informal. The studied cases have shown how cooperation and informal institutions have been useful in dealing with the existing water management challenges, developing conjunctive use and integrating treated wastewater use. The existing local arrangements address issues of equity, restrict groundwater use, deal with common infrastructure, shape the interaction of different sources and provide flexibility, therefore complementing formal policies. However, a formal recognition of these rules in use may also benefit both farmer and authorities.

Drip irrigation is one of the prevailing measures in state-led interventions to improve irrigation efficiency and for demand management. The promotion of drip irrigation is based in an agronomic model seeking to adjust water use to crop water needs. However, community management traditionally has focused in devising arrangements for sharing water in an equitable and transparent way, especially when water becomes scarce.

In many cases, drip irrigation extends over areas previously irrigated by systems of channels which used gravity irrigation for centuries. This entails a process of change and transformation of institutions and organizations managing irrigation. The encounter of both systems results in some paradoxes and challenges for collective drip irrigation management. In this context, WUAs need to find new ways to adapt the characteristics of prior irrigation management to the requirements linked to the new technology.

The studied cases shed light in the necessary assessment of collective drip irrigation. We have shown how drip irrigation could entail important transformations in the organization and could lead to a centralization and technocratization of management. 
In this sense, in contrast with the integration of new water resources, drip implementation made possible to undertake major transformations in the organizations managing irrigation. In contrast to gravity irrigated systems, the existing local arrangements for drip irrigation do not tackle explicitly how to share the resources equitably or to provide incentives to reduce consumption. To recognize the limitations of drip irrigation looking beyond the current dominant agronomic model, including context-specific adjustments and considering actors and their interaction with technology as a part of the innovation will broaden the perspectives in current irrigation policy and ultimately contribute to gain a wider understanding about how drip irrigation can contribute to sustainable water management.

In what follows, a summarized view of the concluding remarks is provided for each chapter:

\section{Chapter 2}

- Principles such as autonomy, contiguity, uniformity (on irrigation frequency and in technique), proportionality and transparency prove appropriate to understand rules reinforcing collective action.

- Community management in the traditional irrigation system in the Huerta of Valencia has been shown to successfully adapt to fluctuation in water supply and severe scarcity.

\section{Chapter 3}

- Conjunctive use including groundwater and treated wastewater was important to deal with the 2005-2008 drought period, increasing the reliability of water supply.

- New water sources may be integrated without major conflict in a system based in surface water use. However, it is important to consider equity implications if these resources introduce differences in the regularity of supply among users.

- The existing organizations have developed rules for self-governance of new water sources and spontaneous "in lieu” conjunctive use, although institutional arrangements hinder a more coordinated use of surface and groundwater. 


\section{Chapter 4}

- The shift to drip irrigation entails a major technical and institutional change. This process has facilitated the integration of infrastructures and the centralization of management.

- Collective irrigation management may imply having to deal with unforeseen effects and diversity of expectations. Therefore, water policies may benefit from a wider understanding and focus on farmer's and WUA's views and motivations to implement drip irrigation.

- It is necessary to incorporate in future policies technical and institutional arrangements, as well as their synergies, in order to achieve the technical and social advantages drip irrigation aims to generate.

\section{Chapter 5}

- The distinction between management and governance was useful to assess the occurred changes and the differences between the studied irrigation systems.

- Both the use of new water sources and drip irrigation has implications for collective water management rules and institutions. However, the important changes entailed by drip irrigation implementation make possible a significant transformation in the organization.

- The disappearance of traditional irrigation systems may entail losing the opportunity to learn about collective practices and arrangements that have been useful to adapt to scarcity. 
From these conclusions, and from the previous discussion, several lines for future research can be drawn:

1. Relevant aspects of collective irrigation management are well captured by Trawick's model $(2008,2001 b)$. In this sense, future research addressing the relative effectiveness of these working rules would be useful to contrast its applicability in different contexts.

2. Reuse strategies seem to be increasing in peri-urban agriculture. Some work has been done in order to assess its extent and importance, but further research is essential. In particular regarding farmer's perception and, in the case of Spain, regarding the compliance with the Spanish legal framework. The current absence of water allowances may result in a loophole or informal use, with implications for health concerns.

3. Cooperation between surface and groundwater management organizations for water use has proved useful to restrict groundwater use while providing flexibility to adapt to scarcity. Similar arrangements are likely to occur in places where different water sources are available. The study and comparison of institutions to govern different water sources would be valuable for finding new manners of coordinated use.

4. In the case of collective implementation of new irrigation technologies user's and manager's perceptions and practices are just starting to be considered. There exist thus promising opportunities to set up context-specific expertise in this area. Furthermore, it is a challenge to devise political schemes, strategies and contexts reconciling the existing differences with water managers towards achieving water conservation objectives.

5. Evaluation of the impacts and unanticipated outcomes of the proposed policy measures, including transformation to drip irrigation projects, is missing. Future research should address these issues.

6. Moreover, the reasons to adopt drip irrigation and its effects need to be addressed considering the cultural and political setting, as well as the role of power relations. This will allow for a more contextualized understanding of water management policies. 



\section{List of Figures}

Figure 1.1. Drip irrigation policies in Spain between 2002 and 2009 . . . . . . 42

Figure 1.2. Evolution of irrigated surface by irrigation method and total water use 44

Figure 1.3. Evolution of water use by irrigation method and total water use . . . 45

Figure 1.4. Research questions. . . . . . . . . . . . . . . . . . . . 49

Figure 1.5. Structure of the Thesis . . . . . . . . . . . . . . . 53

Figure 2.1. WUAs in the Huerta of Valencia.. . . . . . . . . . . . . . . 59

Figure 2.2. Percentages of responses to questions about the operating principles. . 71

Figure 2.3. Percentages of responses to questions about the operating principles. . 73

Figure 3.1. Surface irrigated and location of the WUAs in La Vega de Valencia.

The number of Groundwater User Associations is shown

between brackets in the legend . . . . . . . . . . . 105

Figure 3.2. Response distribution for questions a about basic principles of irrigation with recycled wastewater . . . . . . . . . . . 107

Figure 3.3. Response distribution for questions about basic principles of irrigation with groundwater from GUAs . . . . . . . . . . 109

Figure 4.1. Location of the case studies analyzed. . . . . . . . . . . . . . 121

Figure 4.2. Scheme of the organizations of the analyzed case studies. . . . . . . 123

Figure 4.3. Response distribution for the reasons for adopting drip irrigation . . 128 



\section{List of Tables}

Table 2.1. Service areas of WUAs in the Huerta of Valencia in 2009 and 1965 . . 61

Table 2.2. Pattern of landholdings in the WUA of Real Acequia de Moncada in $2009 \ldots \ldots$. . . . . . . . . . . . . . . . . . . . . . . . . . .

Table 2.3. Categories and numbers of informants . . . . . . . . . . . . 65

Table 2.4. Operating principles of irrigation under scarcity in Valencia . . . . . 68

Table 3.1. Basic principles of irrigation in Huaynacotas adapted to La Vega de Valencia (Trawick, 2008, 2001b). . . . . . . . . . . 98

Table 3.2. Different kinds of organizations in the irrigation system of the Huerta of Valencia and water resources managed . . . . . . . . . . . 99

Table 3.3. Extension of surface and ground and recycled water use in the area of La Vega de Valencia . . . . . . . . . . . . . . . . . 101

Table 3.4. Flow rates from WWTP $\left(\mathrm{m}^{3} / \mathrm{s}\right)$ derived for each WUA . . . . . . . . 104

Table 4.1. Main characteristics of studied areas and farmers interviewed. . . . 125

Table 5.1. Organization, water distribution and channel maintenance for the WUAs in the traditional irrigation systems of la Huerta of Valencia and the Acequia Real del Júcar . . . . . . . . . . . . . . . . . 149 



\section{References}

Agrawal, A., 2002. Common resources and institutional sustainability, in: Ostrom, E., Dietz, T., Dolsak, N., Stern, P.C., Stonich, S., Weber, E.U. (Eds.), The Drama of the Commons. National Academy Press, Washington, DC., pp. 41-85.

Allan, T., 1999. Productive efficiency and allocative efficiency: Why better water management may not solve the problem. Agricultural Water Management 40, 71-75. doi:10.1016/S0378-3774(98)00106-1

Ameur, F., Hamamouche, M.F., Kuper, M., Benouniche, M., 2013. The domestication of a technical innovation: Diffusion of drip irrigation in two villages in morocco. Cahiers Agricultures 22, 311-318. doi:10.1684/agr.2013.0644

Anderies, J.M., Folke, C., Walker, B., Ostrom, E., 2013. Aligning key concepts for global change policy: Robustness, resilience, and sustainability. Ecology and Society 18, 8. doi:10.5751/ES-05178-180208

Anderies, J.M., Janssen, M.A., 2011. The fragility of robust social-ecological systems. Global Environmental Change 21, 1153-1156. doi:10.1016/j. gloenvcha.2011.07.004

Anderies, J.M., Janssen, M.A., Ostrom, E., 2004. A framework to analyze the robustness of social-ecological systems from an institutional perspective. Ecology and Society 9, 18, [WWW Document] URL http://www.ecologyandsociety.org/vol9/iss1/ $\operatorname{art} 18 /$.

Andreu, J., Sahuquillo, A., Solera, A., Pulido-Velazquez, M., Pulido-Velazquez, D., Paredes, J., 2010. Uso conjunto de aguas superficiales y subterráneas., in: Proceedings of the XII Congreso Nacional de Comunidades de Regantes de España. Tarragona, Spain.

Araral, E., 2014. Ostrom, Hardin and the commons: A critical appreciation and a revisionist view. Environmental Science \& Policy, Interrogating The Commons 36, 11-23. doi:10.1016/j.envsci.2013.07.011 
Avellá, L., Carles, J., Sanchis-Ibor, C., 2009. La Directiva Marco de Agua: ¿Un modelo alternativo del uso del agua?, in: Gómez-Limón, J.A., Calatrava, J., Garrido, A., Sáez, J., Xabadia, À. (Eds.), La Economía Del Agua de Riego En España. Una Perspectiva Regional. Fundación Cajamar, Almería, Spain.

Aymard, M., 1864. Irrigations de midi de l'Espagne. Lacroix, Paris.

Bakker, K., 2011. The ambiguity of community: debating alternatives to private-sector provision of urban water supply. Water Alternatives 1, 236-252.

Bakker, K., 2007. The "commons" versus the "commodity": Alter-globalization, antiprivatization and the human right to water in the global South. Antipode 39, 430-455.

Baland, J.M., Platteau, P., 1996. Halting degradation of natural resources: is there a role for rural communities? Food and Agricultural Association of the United Nations, Rome, Italy.

Barba-Romero, J., Corchón, F., Ferrer-Polo, J., 1998. Determinación del perímetro de delimitación de los acuíferos utilizados por la Comunidad de Regantes dela Vall d'Uixó (Castellón), in: Jornadas sobre la contaminación de las aguas subterraneas: un problema pendiente. Valencia 1998. AIH-GE. pp. 373-379.

Barbero, Á., 2006. The Spanish National Irrigation Plan, in: OECD (Ed.), Water and agriculture: sustainability, markets and policies. OECD Publishing, Paris.

Bardhan, P., 2000. Irrigation and Cooperation: An Empirical Analysis of 48 Irrigation Communities in South India. Economic Development and Cultural Change 48, $845-865$.

Bardhan, P., Dayton-Johnson, J., 2002. Unequal irrigators: Heterogeneity and commons management in large-Scale multivariate research, in: The drama of the commons. National Academies Press, Washington, DC., pp. 87-112.

Bebbington, A., 2009. The new extraction: Rewriting the political ecology of the Andes. NACLA Report on the Americas 45, 12-20.

Benouniche, M., Kuper, M., Hammani, A., Boesveld, H., 2014a. Making the user visible: analysing irrigation practices and farmers' logic to explain actual drip irrigation performance. Irrigation Science 32, 405-420. doi:10.1007/s00271014-0438-0. 
Benouniche, M., Kuper, M., Poncet, J., Hartani, T., Hammani, A., 2011. Quand les petites exploitations adoptent le goutte-à-goutte : initiatives locales et programmes étatiques dans le Gharb (Maroc). Cahiers Agricultures 20, 40-47. doi:10.1684/ agr.2011.0476

Benouniche, M., Zwarteveen, M., Kuper, M., 2014b. Bricolage as innovation: Opening the black box of drip irrigation systems. Irrigation and Drainage 63, 651-658. doi:10.1002/ird.1854

Bharadwaj, K., 1990. Irrigation in India: alternative perspectives, research in economics: second survey, monograph 3. india Council of Social Science Research.

Bijker, W.E., Hughes, T.P., Pinch, T., 2012. The social construction of technological systems: New directions in the sociology and history of technology, Anniversary ed. ed. MIT Press, Cambridge, US.

Blomquist, W., Heikkila, T.A., Schlager, E., 2001. Institutions and conjunctive water management among three western states. Natural Resources Journal 41, 653684.

Blomquist, W., Schlager, E., Heikkila, T., 2004. Common waters, diverging streams. Linking institutions and water management in Arizona, California y Colorado. Resources for the Future, Washington, DC.

Blomquist, W., Schlager, E., Tang, S.Y., Ostrom, E., 1994. Regularities from the field and possible explanations, in: Ostrom, E., Gardner, R., Walker, J. (Eds.), Rules, Games and Common-Pool Resources. University of Michigan press, Ann Arbor, US, pp. 301-318.

BOE, (Boletín Oficial del Estado - Spanish Official Gazette), 2009. Real Decreto Ley 14/2009, por el que se adoptan medidas urgentes para paliar los efectos producidos por la sequía en determinadas cuencas hidrográficas, 4th December. 293 of 5/12/2009, 103532-103544.

BOE, (Boletín Oficial del Estado - Spanish Official Gazette), 2008. Real Decreto $1725 / 2007$, por el que cierran las inversiones del primer horizonte del Plan Nacional de Regadíos en mejora y consolidación de regadíos, 21st December. 14 of $16 / 01 / 2008,3137-3140$. 
BOE, (Boletín Oficial del Estado - Spanish Official Gazette), 2007. Orden MAM/698/2007 por la que se aprueban los planes especiales de actuación en situaciones de alerta y eventual sequía en los ámbitos de los planes hidrológicos de cuencas intercomunitarias, 21 st May. 71 of 23/3/2007, 12820-12821.

BOE, (Boletín Oficial del Estado - Spanish Official Gazette), 2006. Real Decreto 287/2006, por el que se regulan las obras urgentes de mejora y consolidación de regadíos, con objeto de obtener un adecuado ahorro de agua que palie los daños producidos por la sequía, 10th March. 60 of 11/03/2006, 9848-9858.

BOE, (Boletín Oficial del Estado - Spanish Official Gazette), 2005. Real Decreto Ley $10 / 2005$, por el que se adoptan medidas urgentes para paliar los daños producidos en el sector agrario por la sequía y otras adversidades climáticas, 20th June. 147 of 21/06/2005, 21542-21551.

BOE, (Boletín Oficial del Estado - Spanish Official Gazette), 2002. Real Decreto 329/2002, por el que se aprueba el Plan Nacional de Regadíos, 5th April. 101 of 27/04/2002, 15558-15566.

BOE, (Boletín Oficial del Estado - Spanish Official Gazette), 2001. Real Decreto Legislativo 1/2001 por el que se aprueba el texto refundido de la Ley de Aguas, 20th July. 176 of 24/07/2001, 26791-26817.

BOE, (Boletín Oficial del Estado - Spanish Official Gazette), 1985. Ley 29/1985 de Aguas, 2nd August. 1989 of 8/8/1985, 25123-25135.

Boelens, R., 2014. Cultural politics and the hydrosocial cycle: Water, power and identity in the Andean highlands. Geoforum 57, 234-247. doi:10.1016/j. geoforum.2013.02.008

Boelens, R., 2008. The game of the rules and the rules of the game: normalization and resistance in Andean water control (PhD Dissertation). Wageningen University, Wageningen, Netherlands.

Boelens, R., Dávila, G., 1998. Searching for equity: Conceptions of justice and equity in peasant irrigation. Van Gorcum \& Comp, Assen, Netherlands.

Boelens, R., Hoogendam, P., 2002. Water rights and empowerment. Koninklijke Van Gorcum, Assen, Netherlands. 
Boelens, R., Vos, J., 2012. The danger of naturalizing water policy concepts: Water productivity and efficiency discourses from field irrigation to virtual water trade. Agricultural Water Management, Irrigation efficiency and productivity: scales, systems and science 108, 16-26. doi:10.1016/j.agwat.2011.06.013

Bolding, A., Mollinga, P., Vanstraaten, K., 1995. Modules for modernization - colonial irrigation in india and the technological dimension of agrarian change. Journal of Development Studies 31, 805-844. doi:10.1080/00220389508422392

Bouarfa, S., Kuper, M., 2012. Groundwater in irrigation systems: From menace to mainstay. Irrigation and Drainage 61, 1-13. doi:10.1002/ird.1651

Brown, J.R., Rivera, J.A., 2000. Acequias de Común: The tension between collective action and private property rights, in: Papers \& Abstracts, Workshop in Political Theory and Policy Analysis, Indiana University, [CD-ROM ISBN 1-889740047], IASCP 2000.

Brunhes, J., 1902. L'irrigation, ses conditions géographiques, ses modes et son organisation dans la Péninsule Ibérique et dans l'Afrique du Nord. Naud, Paris.

Burke, E.J., Brown, S.J., Christidis, N., 2006. Modeling the recent evolution of global drought and projections for the twenty-first century with the hadley centre climate model. Journal of Hydrometeorology 7, 1113-1125. doi:10.1175/JHM544.1

Calatayud, S., 2004. Canals d'innovació tecnològica a l'agricultura mediterrània occidental (1840-1930). Recerques 49, 25-52.

Cameira, M.R., Pereira, A., Ahuja, L., Ma, L., 2014. Sustainability and environmental assessment of fertigation in an intensive olive grove under Mediterranean conditions. Agricultural Water Management 146, 346-360. doi:10.1016/j. agwat.2014.09.007

Carles-Genovés, J., García-Mollá, M., 2003. La coherencia de las instituciones y los modelos de uso del agua, in: Albiac, J. (Ed.), Los instrumentos económicos en la gestión del agua en la agricultura. Madrid, Spain, pp. 115-127.

Carles-Genovés, J., García-Mollá, M., Sanchis-Ibor, C., Vega-Carrero, V., Avellá-Reus, L., 2008. ISIIMM project: Case studies synthesis. Spain, Institutional and Social Innovations in Irrigation Mediterranean Management. 
Carmona, P., Ruiz, J.M., 2007. El medio físico. El territorio como escenario de los regadios históricos., in: Hermosilla, ESTEPA (Eds.), El patrimonio hidráulico del bajo Turia. L'Horta de Valencia. Consellería de Cultura y Deporte de la Generalitat Valenciana, Valencia, Spain, pp. 30-44.

Carr, G., Potter, R.B., Nortcliff, S., 2011. Water reuse for irrigation in Jordan: Perceptions of water quality among farmers. Agricultural Water Management 98, 847-854. doi:10.1016/j.agwat.2010.12.011

Clemmens, A.J., Molden, D.J., 2007. Water uses and productivity of irrigation systems. Irrigation Science 25, 247-261. doi:10.1007/s00271-007-0067-y

Collett, B., Henry, N., 2014. Water justice: exploring the social dimensions of new irrigation technologies in northern Victoria, Australia. Water Policy 16, 155173. doi:10.2166/wp.2014.102

Costejà-Florensa, M., 2009. Adaptabilidad institucional. Dinámicas en la evolución de los sistemas socio-ecológicos del uso del agua en España (PhD Dissertation). Universidad Autonoma de Barcelona, Barcelona, Spain.

Coward, E., 1990. Property Rights and Network Order: The Case of irrigation works in the western himalayas. Human Organization 49, 78-88. doi:10.17730/ humo.49.1.g53435062n67k2g2

Coward, E.W., 1985. Planning tecnical and social change in irrigated areas, in: Cernea, M.M. (Ed.), Putting People First: Sociological Variables in Rural Development. Oxford University Press for the World Bank, New York, pp. 46-72.

Coward, E.W., 1979. Principles of social-organization in an indigenous irrigation system. Human Organization 38, 28-36.

Coward, E.W., 1976. Indigenous organization, bureaucracy and development - case of irrigation. Journal of Development Studies 13, 92-105. doi:10.1080/00220387608421610

Cox, M., Ross, J.M., 2011. Robustness and vulnerability of community irrigation systems: The case of the Taos valley acequias. Journal of Environmental Economics and Management 61, 254-266. doi:10.1016/j.jeem.2010.10.004

de Graaff, J., Amsalu, A., Bodnár, F., Kessler, A., Posthumus, H., Tenge, A., 2008. Factors influencing adoption and continued use of long-term soil and water conservation measures in five developing countries. Applied Geography 28, 271280. doi:10.1016/j.apgeog.2008.05.001 
Del Moral, L., 2009. Changing discourses in a modern society, in: Garrido, A., Llamas, M.R. (Eds.), Water Policy in Spain. Taylor and Francis, London, pp. 85-93.

Dietz, T., Ostrom, E., Stern, P.C., 2003. The struggle to govern the commons. Science 302, 1907-1912.

Eisenhardt, K.M., Graebner, M.E., 2007. Theory Building From Cases: Opportunities And Challenges. Academy of Management Journal 50, 25-32. doi:10.5465/ AMJ.2007.24160888

Favretto, C., 2004. El Tribunal de las Aguas: mito y evolución reciente. Braçal. Revista del Centre d'Estudis. Proceedings of the 1er Congrés sobre el Patrimoni Cultural Valencià. Camp de Morvedre, Spain. 28-29, 195-211.

Faysse, N., Petit, O., 2012. Convergent readings of groundwater governance? engaging exchanges between different research perspectives. Irrigation and Drainage 61, 106-114. doi:10.1002/ird.1654

Feeny, D., Berkes, F., McCay, B.J., Acheson, J.M., 1990. The tragedy of the commons: Twenty-two years later. Human Ecology 18, 1-19. doi:10.1007/BF00889070

Fissel, B.E., Gilbert, B., LaRiviere, J., 2013. Technology adoption and diffusion with uncertainty in a commons. Economics Letters 120, 297-301. doi:10.1016/j. econlet.2013.04.048

Foster, S., van Steenbergen, F., Zuleta, J., Garduño, H., 2010. Conjunctive use of groundwater and surface water. From spontaneous coping strategy to adaptative resource management., in: Strategic Overview Series. Number 2. World Bank, Washington, DC.

Ftaïta, T., 2010. Community water management. Is it still possible? Anthropological perspectives. Anuário Antropológico, Brasília, UnB 2, 195-212.

Garb, Y., Friedlander, L., 2014. From transfer to translation: Using systemic understandings of technology to understand drip irrigation uptake. Agricultural Systems 128, 13-24. doi:10.1016/j.agsy.2014.04.003

García-Mollá, M., Ortega Reig, M., Sanchis-Ibor, C., Avellá-Reus, L., 2014. The effects of irrigation modernization on the cost recovery of water in the Valencia Region (Spain). Water Science \& Technology: Water Supply 14, 414-420. 
García-Mollá, M., Sanchis-Ibor, C., Ortega-Reig, M.V., Avellá-Reus, L., 2013. Irrigation associations coping with drought: The case of four irrigation districts in eastern Spain, in: Schwabe, K., Albiac, J., Connor, J.D., Hassan, R.M., González, L.M. (Eds.), Drought in Arid and Semi-Arid Regions. Springer Netherlands, pp. 101122.

Garrido, S., 2014. Water management, spanish irrigation communities and colonial engineers. Journal of Agrarian Change 14, 400-418. doi:10.1111/joac.12042

Garrido, S., 2012. Expansion of irrigation, institutional regulation and sustainability on the traditional huertas of Mediterranean Spain. Investigaciones de Historia Economica 8, 94-103. doi:10.1016/j.ihe.2011.08.017

Garrido, S., 2011. Las instituciones de riego en la España del este: una reflexión a la luz de la obra de Elinor Ostrom. Historia agraria 53, 13-42.

Gelles, P.H., 2000. Water and power in highland Peru: the cultural politics of irrigation and development. Rutgers University Press, New Brunswick, United States.

Gil-Meseguer, E., 2010. La Región de Murcia, un laboratorio de experiencias de ahorro y eficiencia en el uso del agua: la modernización de sus regadíos, entre las políticas agraria y ambiental de la Unión Europea. Papeles de Geografía 51-52, 131-146.

Gimenez-Casalduero, M., Palerm-Viqueira, J., 2007. Organizaciones tradicionales de gestión del agua: importancia de su reconocimiento legal para su pervivencia. El caso de España. Region y Sociedad 19, 3-24.

Giordano, M., Villholth, K.G., 2007. The agricultural groundwater revolution: setting the scene, in: The Agricultural Groundwater Revolution. Opportunities and Threats to Development. CABI, Wallingford, UK, pp. 1-4.

Glick, T.F., 2010. Discurso de aceptación. Acto de Investidura como Doctor "Honoris Causa" del Excm. Sr. Dr. Thomas F. Glick. Universitat de València, Valencia.

Glick, T.F., 1991. Estudi preliminar, in: Informe sobre el regadiu de l'Espanya de l'Est, Col-lecció politècnica. Alfons el Magnànim, Institució Valenciana d'Estudis i Investigacio, Burjassot, Spain.

Glick, T.F., 1970. Irrigation and society in medieval Valencia. Harvard University Press, Cambridge, US.

Gómez-Espín, J.M., Gil-Meseguer, E., García-Marín, R., 2006. El antes y después de la modernización de regadíos: la experiencia de Mula. Servicio de Publicaciones. Universidad de Murcia, Murcia, Spain. 
Gómez-Limón, J.A., Martin-Ortega, J., 2013. The economic analysis in the implementation of the Water-Framework Directive in Spain. International Journal of River Basin Management 11, 301-310. doi:10.1080/15715124.201 3.823977

González-Pérez, A., Guzmán-Puente, M., Palerm-Viqueira, J., 2013. El riego por mangueras en ladera: los ejidos de Metepec, Morelos, in: Palerm Viqueira, J., Martínez-Saldaña, T. (Eds.), Antología sobre riego. Instituciones para la gestión del agua: vernáculas, alegales e informales. Biblioteca Básica de Agricultura: Colegio de Postgraduados, Montecillo, México, pp. 335-343.

Greiner, R., Gregg, D., 2011. Farmers' intrinsic motivations, barriers to the adoption of conservation practices and effectiveness of policy instruments: Empirical evidence from northern Australia. Land Use Policy 28, 257-265. doi:10.1016/j. landusepol.2010.06.006

Greiner, R., Patterson, L., Miller, O., 2009. Motivations, risk perceptions and adoption of conservation practices by farmers. Agricultural Systems 99, 86-104. doi:10.1016/j.agsy.2008.10.003

Guillet, D., 2000. Reconsidering institutional change: property rights in northern Spain. American Anthropologist 102, 713-725. doi:10.1525/aa.2000.102.4.713

Guillet, D., 1997. Ground Water Irrigation and Property Rights in Northwestern Spain. Political Legal Anthropology Review 20, 144-163. doi:10.1525/ pol.1997.20.2.144

Guinot, E., 2007. Una historia de La Huerta de Valencia, in: Hermosilla, J., ESTEPA (Eds.), El Patrimonio Hidráulico Del Bajo Turia. L'Horta de València. Consellería de Cultura y Deporte de la Generalitat Valenciana, Valencia, Spain, pp. 60-101. Hardin, G., 1968. The tragedy of commons. Science 162, 1243-1248.

Hunt, R.C., 1989. Appropriate social-organization? Water user associations in bureaucratic canal irrigation systems. Human Organization 48, 79-90.

Hunt, R.C., 1988. Size and the structure of authority in canal irrigation systems. J. Anthropol. Res. 44, 335-355.

Hunt, R.C., Hunt, E., 1976. Canal irrigation and local social-organization. Current Anthropology 17, 389-411. doi:10.1086/201755 
ICID, (International Commission on Irrigation \& Drainage), 2012. ICID Database. Sprinkler and micro irrigated area [WWW Document]. URL http://www.icid. org/icid_data.html (accessed 7.17.15).

Janat, M., 2008. Response of cotton to irrigation methods and nitrogen fertilization: Yield components, water-use efficiency, nitrogen uptake, and recovery. Communications in Soil Science and Plant Analysis 39, 2282-2302. doi:10.1080/00103620802292293

Janat, M., 2007. Efficiency of nitrogen fertilizer for potato under fertigation utilizing a nitrogen tracer technique. Communications in Soil Science and Plant Analysis 38, 2401-2422. doi:10.1080/00103620701588775

Jansen, K., Vellema, S., 2011. What is technography? NJAS - Wageningen Journal of Life Sciences, Technography and Interdisciplinarity: Performance, Practices and Experiments 57, 169-177. doi:10.1016/j.njas.2010.11.003

Janssen, M.A., Anderies, J.M., Ostrom, E., 2007. Robustness of social-ecological systems to spatial and temporal variability. Society \& Natural Resources 20, 307-322. doi:10.1080/08941920601161320

Jaubert de Passa, J.F., 1823. Voyage en Espagne, dans les années 1816, 1817, 1818, 1819, ou, Recherches sur les arrosages, sur les lois et coûtumes qui les régissent, sur les lois domaniales et municipales, considérés comme un puissant moyen de perfectionner l'agriculture française, Huzard. ed. Paris.

JDWA, (Júcar District Water Authority), 2014a. Plan Hidrológico de Cuenca 20092015. Anejo 3. Usos y demandas de agua [WWW Document]. URL http:// www.chj.es/es-es/medioambiente/planificacionhidrologica/Paginas/PHC-20092015-Plan-Hidrologico-cuenca.aspx (accessed 1.13.15).

JDWA, (Júcar District Water Authority), 2014b. Proposal of project of revision of the Hydrological Plan. Resport. Annex 10. Programme of measures. Cycle of hydrologic planning 2015-2012. Júcar Hydrographic Demarcation. Phase of Public Consultation [WWW Document]. URL http://www.chj.es/Descargas/ ProyectosOPH/Consulta\%20publica/PHC-2015-2021/PHJ1521_CP_ Anejo10_PdM.pdf

JDWA, (Júcar District Water Authority), 2003. Estudio de utilizacion conjunta de los recursos superficiales y subterraneos de la Cuenca media y baja los rios Júcar y Turia [WWW Document]. URL http://www.chj.es/web/pdf/SintUsoconVersPubl.pdf 
Jensen, M.E., 2007. Beyond irrigation efficiency. Irrigation Science 25, 233-245. doi:10.1007/s00271-007-0060-5

Kessler, C.A., 2006. Decisive key-factors influencing farm households' soil and water conservation investments. Applied Geography 26, 40-60. doi:10.1016/j. apgeog.2005.07.005

Khan, B.M., 1984. Water management in Pakistan; in Participatory experiences in irrigation water management, Proceedings of the Expert Consultation on Irrigation Water Management. Food and Agriculture Organization of the United Nations, Yogyakarta and Bali, Indonesia, pp. 169-179.

Korten, R.F., 1982. Building capacity to develop water users' associations: experience from the Philippines (No. 528), World Bank Staff Working Papers. World Bank, Washington, DC.

Koundouri, P., Nauges, C., Tzouvelekas, V., 2006. Technology adoption under production uncertainty: Theory and application to irrigation technology. American Journal of Agricultural Economics 88, 657-670. doi:10.1111/j.14678276.2006.00886.x

Kuper, M., Dionnet, M., Hammani, A., Bekkar, Y., Garin, P., Bluemling, B., 2009. Supporting the shift from state water to community water: Lessons from a social learning approach to designing joint irrigation projects in Morocco. Ecology and society 14, 19 [WWW Document] URL http://www.ecologyandsociety.org/ vol14/iss1/art19/.

Kuper, M., Hammani, A., Chohin, A., Garin, P., Saaf, M., 2012. When groundwater takes over: Linking 40 years of agricultural and groundwater dynamics in a large-scale irrigation scheme in Morocco. Irrigation and Drainage 61, 45-53. doi:10.1002/ird.1653

Lam, W.F., 1998. Governing irrigation systems in Nepal: Institution, infrastructure, and collective action. Institute for Comparative Studies Press, Oakland, US.

Lam, W.F., 1996. Improving the performance of small-scale irrigation systems: The effects of technological investments and governance structure on irrigation performance in Nepal. World Development 24, 1301-1315. doi:10.1016/0305750X(96)00043-5 
Lana-Berasain, J.M., 1999. Los regadíos navarros entre el Antiguo Régimen y la Guerra Civil. Una aproximación a sus características técnicas e institucionales. Gerónimo de Uztariz 14-15, 201-222.

Lansing, J.S., 1987. Balinese "Water Temples" and the management of irrigation. American Anthropologist 89, 326-341. doi:10.1525/aa.1987.89.2.02a00030

Lansing, S., 2006. Perfect order: Recognizing complexity in Bali. Princeton University Press, Princeton, US.

Lansing, S., 1991. Priests and Programmers: Technologies of power in the engineered landscape of Bali. Princeton University Press, Princeton, US.

Lecina, S., Isidoro, D., Playán, E., Aragüés, R., 2010a. Irrigation modernization and water conservation in Spain: The case of Riegos del Alto Aragón. Agricultural Water Management 97, 1663-1675. doi:10.1016/j.agwat.2010.05.023

Lecina, S., Isidoro, D., Playán, E., Aragüés, R., 2010b. Irrigation modernization in Spain: Effects on water quantity and quality - A conceptual approach. International Journal of Water Resources Development 26, 265-282. doi:10.1080/07900621003655734

López-Gunn, E., 2009. Agua para todos: A new regionalist hydraulic paradigm in Spain. Water Alternatives 2, $370-394$.

López-Gunn, E., Mayor, B., Dumont, A., 2012a. Implications of the modernization of irrigation systems, in: De Stefano, L., Llamas, R. (Eds.), Agriculture and the Environment in Spain: Can We Square the Circle? Fundación Botín, Madrid, Spain, pp. 241-255.

López-Gunn, E., Zorrilla, P., Prieto, F., Llamas, M.R., 2012b. Lost in translation? Water efficiency in Spanish agriculture. Agricultural Water Management, Special Issue: Irrigation efficiency and productivity: scales, systems and science 108, 83-95. doi:10.1016/j.agwat.2012.01.005

Luján, J.L., Moreno, L., 1996. El cambio tecnológico en las ciencias sociales: El estado de la cuestión. Reis 74, 127-161. doi:10.2307/40183888

Luquet, D., Vidal, A., Smith, M., Dauzat, J., 2005. "More crop per drop": how to make it acceptable for farmers? Agricultural Water Management 76, 108-119. doi:10.1016/j.agwat.2005.01.011

Maass, A., Anderson, R.L., 1978. ... and the desert shall rejoice: conflict, growth and justice in arid environments. MIT Press, Cambridge, US. 
Mabry, J.B., Cleaveland, D.A., 1996. The relevance of indigenous irrigation: A Comparative Analysis of Sustainability, in: Canals and Communities: SmallScale Irrigation Systems. University of Arizona Press, Tucson, US, pp. 227-259.

MAGRAMA, (Ministry of Agriculture Food and Environment), 2015a. Encuesta sobre Superficies y Rendimientos Cultivos (ESYRCE): informe sobre regadío en España. 2014 [WWW Document]. URL http://www.magrama.gob.es/es/ estadistica/temas/estadisticas-agrarias/agricultura/esyrce/informes-sectoriales/ (accessed 4.27.15).

MAGRAMA, (Ministry of Agriculture Food and Environment), 2015b. Serie de datos de los valores de precipitación media por demarcación. Años 1999-2010. [WWW Document]. URL http://www.ine.es/jaxi/menu.do?type=pcaxis\&file=pcaxis\&pa th=\%2Ft26\%2Fp067\%2Fp03\%2F\%2Fa2005 (accessed 5.1.15).

MAGRAMA, (Ministry of Agriculture Food and Environment), 2009a. Recurrencia y efectos de la sequia [WWW Document]. URL http://www.magrama.gob.es/es/ desarrollo-rural/temas/politica-forestal/rec_ef_sequia_tcm7-18356.pdf (accessed 7.9.15).

MAGRAMA, (Ministry of Agriculture Food and Environment), 2009b. Observationio nacional de la sequía. Medidas implantadas. Medidas legislativas y normativas: textos legales [WWW Document]. URL http://www.magrama.gob.es/en/ desarrollo-rural/temas/politica-forestal/desertificacion-restauracion-forestal/ lucha-contra-la-desertificacion/textos_legales.aspx (accessed 7.9.15).

MAGRAMA, (Ministry of Agriculture Food and Environment), 2007. Plan especial de alerta y eventual sequía en la Confederación Hidrográfica del Júcar [WWW Document]. URL http://www2.chj.gob.es/docus/oph/PES_Marzo_2007.pdf (accessed 12.19.12).

MAGRAMA, (Ministry of Agriculture Food and Environment), 1998. Libro Blanco del Agua. Docummento de sintesis [WWW Document]. URL http://www. magrama.gob.es/es/agua/temas/planificacion-hidrologica/libro-blanco-del-agua/ (accessed 7.7.15).

MAGRAMA, (Ministry of Agriculture Food and Environment), n.d. Plan Nacional de Regadios [WWW Document]. URL http://www.magrama.gob.es/es/desarrollorural/temas/gestion-sostenible-regadios/plan-nacional-regadios/texto-completo/ (accessed 8.30.15). 
Malhotra, S.P., 1982. The Warabandi system and its infrastructure. Central board of irrigation and power of India, New Delhi.

Mangue-Alférez, I., 2011. Poder Polític, rebel.lió i lluita per l'aigua a l'Horta de València. Godella, la sindicatura perduda de la Séquia de Montcada, in: Actes del III Congrés d'estudis de L'Horta Nord. Universitat Politècnica de València, Valencia, Spain, pp. 119-139.

Mansbridge, J., 2014. The role of the state in governing the commons. Environmental Science \& Policy, Interrogating The Commons 36, 8-10. doi:10.1016/j. envsci.2013.07.006

Marra, M., Pannell, D.J., Abadi Ghadim, A., 2003. The economics of risk, uncertainty and learning in the adoption of new agricultural technologies: where are we on the learning curve? Agricultural Systems 75, 215-234. doi:10.1016/S0308521X(02)00066-5

Marshall, G.R., 2005. Economics for collaborative environmental management: renegotiating the commons. Earthscan, London.

Martínez, F., 2006. Els espais hidràulics de Picassent: l'expansió del regadiu durant els segles XVIII al XX. Ajuntament de Picassent, Beniparrell, Spain.

Medellín-Azuara, J., Howitt, R.E., Harou, J.J., 2012. Predicting farmer responses to water pricing, rationing and subsidies assuming profit maximizing investment in irrigation technology. Agricultural Water Management, Irrigation efficiency and productivity: scales, systems and science 108, 73-82. doi:10.1016/j. agwat.2011.12.017

Meinzen-Dick, R., 2007. Beyond panaceas in water institutions. Proceedings of the National Academy of Sciences 104, 15200-15205. doi:10.1073/ pnas.0702296104

Miranda Ivars, M., 2011. Análisis de la problemática actual en el funcionamiento de hidrantes en redes colectivas de riego a presión. Diseño de un hidrante tipo y elaboración de las prescripciones técnicas que deben cumplir los elementos que lo componen (MSc Thesis). Universitat Politècnica de València, Valencia, Spain.

Moench, M., 2007. When the well runs dry but the livelelihood continues: adaptative responses to groundwater depletition and strategies for mitigating the associated impacts, in: The Agricultural Groundwater Revolution. Opportunities and Threats to Development. CABI, Wallingford, UK, pp. 173-192. 
Molle, F., 2008. Nirvana concepts, narratives and policy models: Insights from the water sector. Water Alternatives 1, 131-156.

Molle, F., 2005. Irrigation and water policies in the Mekong region: Current discourses and practices (IWMI Research Report No. 95). International Irrigation Management Institute (IIMI), Colombo, Sri Lanka.

Mollinga, P.P., 2014. Canal irrigation and the hydrosocial cycle: The morphogenesis of contested water control in the Tungabhadra Left Bank Canal, South India. Geoforum 57, 192-204. doi:10.1016/j.geoforum.2013.05.011

Mollinga, P.P., 2009. Towards the transdisciplinary engineer: Incorporating ecology, equity and democracy concerns into water professionals' attitudes, skills and knowledge. Irrigation and Drainage 58, S195-S204. doi:10.1002/ird.510

Mollinga, P.P., Meinzen-Dick, R.S., Merrey, D.J., 2007. Politics, plurality and problemsheds: A strategic approach for reform of agricultural water resources Management. Development Policy Review 25, 699-719. doi:10.1111/j.14677679.2007.00393.x

Mosse, D., 2006a. Rule and representation: Transformations in the governance of the water commons in British South India. The Journal of Asian Studies 65, 61-90. doi:10.1017/S0021911806000064

Mosse, D., 2006b. Collective action, common property, and social capital in South India: An anthropological commentary. Economic Development and Cultural Change 54, 695-724. doi:10.1086/500034

Mosse, D., 2003. The rule of water: statecraft, ecology and collective action in South India. Oxford University Press, New Delhi.

Mukhtarov, F., Fox, S., Mukhamedova, N., Wegerich, K., 2015. Interactive institutional design and contextual relevance: Water user groups in Turkey, Azerbaijan and Uzbekistan. Environmental Science \& Policy, Special issue: Crafting or designing? Science and politics for purposeful institutional change in Social-Ecological Systems 53, Part B, 206-214. doi:10.1016/j.envsci.2014.10.006

Narain, V., 2003. Institutions, technology, and water control: Water users associations and irrigation management reform in two large-scale systems in India, Wageningen University Water Resources Series. Orient Longman, Hyderabad, India. 
NSI, (National Statistics Institute), 2009. Censo Agrario 2009 [WWW Document]. URL www.ine.es (accessed 6.5.15).

OECD, (Organisation for Economic Co-operation and Development), 2013. Making water reform happen in Mexico. Organization for Economic Cooperation and Development Publishing. doi:10.1787/9789264187894-en.

OECD, (Organisation for Economic Co-operation and Development), 2010. Economic surveys: Spain, December 2010. Overview [WWW Document]. URL http:// www.oecd.org/eco/46654901.pdf (accessed 7.7.15).

OECD, (Organisation for Economic Co-operation and Development), 2008. Environmental performance of agriculture in OECD countries since 1990: Spain Country Section. Paris [WWW Document]. URL http://www.oecd.org/ spain/40806906.pdf

OECD, (Organisation for Economic Co-operation and Development), 2007. European Union, in: Agricultural Policies in OECD Countries 2007 Monitoring and Evaluation: Monitoring and Evaluation. OECD Publishing, pp. 99-167.

Oppong Danso, E., Abenney-Mickson, S., Sabi, E.B., Plauborg, F., Abekoe, M., Kugblenu, Y.O., Jensen, C.R., Andersen, M.N., 2015. Effect of different fertilization and irrigation methods on nitrogen uptake, intercepted radiation and yield of okra (Abelmoschus esculentum L.) grown in the Keta Sand Spit of Southeast Ghana. Agricultural Water Management, Agricultural Water Management: Priorities and Challenges 147, 34-42. doi:10.1016/j.agwat.2014.07.029

Ortega-Reig, M., 2011. La robustez frente a la sequía en los sistemas comunales: El caso de la gestión del agua en la Real Acequia de Moncada (PhD Dissertation Preliminary Report). Universitat Politècnica de Valencia, Valencia, Spain.

Ortega-Reig, M., 2009. Equity and transparency: Overlapping surface and groundwater communities in a traditional irrigation system in Valencia, Eastern Spain (MSc Thesis). Cranfield University, Cranfield, UK.

Ostrom, E., 2007. A diagnostic approach for going beyond panaceas. Proceedings of the National Academy of Sciences 104, 15181-15187. doi:10.1073/ pnas.0702288104

Ostrom, E., 2005. Understanding institutional diversity. Princeton University Press, Woodstock, US. 
Ostrom, E., 2002. The challenge of underperformance, in: Improving Governance and Irrigation Systems in Nepal. Institute for Comparative Studies Press, Oakland, US.

Ostrom, E., 1998. A behavioral approach to the rational choice theory of collective action. American Political Science Review 92, 1-22. doi:10.2307/2585925

Ostrom, E., 1992. Crafting institutions for self-governing irrigation systems. ICS Press, San Francisco, US.

Ostrom, E., 1990. Governing the commons: the evolution of institutions for collective action. Cambridge University Press, Cambridge, UK.

Ostrom, E., Gardner, R., 1993. Coping with asymmetries in the commons: selfgoverning irrigation systems can work. Journal of Economic Perspectives 7, 93112.

Pahl-Wostl, C., 2009. A conceptual framework for analysing adaptive capacity and multilevel learning processes in resource governance regimes. Global Environmental Change 19, 354-365. doi:10.1016/j.gloenvcha.2009.06.001

Pahl-Wostl, C., 2007a. Transitions towards adaptive management of water facing climate and global change. Water Resources Management 21, 49-62. doi:10.1007/ s11269-006-9040-4

Pahl-Wostl, C., 2007b. The implications of complexity for integrated resources management. Environmental Modelling \& Software, Special Issue: The Implications of Complexity for Integrated Resources. The Second Biannual Meeting of the International Environmental Modelling and Software Society: Complexity and Integrated Resources Management 22, 561-569. doi:10.1016/j. envsoft.2005.12.024

Pahl-Wostl, C., Giupponi, C., Richards, K., Binder, C., de Sherbinin, A., Sprinz, D., Toonen, T., van Bers, C., 2013. Transition towards a new global change science: Requirements for methodologies, methods, data and knowledge. Environmental Science \& Policy, Special Issue: Responding to the Challenges of our Unstable Earth (RESCUE) 28, 36-47. doi:10.1016/j.envsci.2012.11.009

Pahl-Wostl, C., Kabat, P., Möltgen, 2007. Adaptive and integrated water management: Coping with complexity and uncertainty. Springer-Verlag, Berlín. 
Pahl-Wostl, C., Lebel, L., Knieper, C., Nikitina, E., 2012. From applying panaceas to mastering complexity: Toward adaptive water governance in river basins. Environmental Science \& Policy 23, 24-34. doi:10.1016/j.envsci.2012.07.014 Palerm-Viqueira, J., 2009. Governance and management of irrigation systems. Water Policy 11, 330. doi:10.2166/wp.2009.042

Palerm-Viqueira, J., Martínez-Saldaña, T., 2000. Antología sobre pequeño riego, vol.II, Organizaciones autogestivas. Plaza y Valdés-Colegio de Postgraduados, México. Pasapera, M.S., 1902. La Ley de Aguas con sus antecedentes. Imprenta y Libreria de San Pedro, Lima.

Peris-Albentosa, T., 2014a. Los conflictos por el agua en territorio valenciano durante los siglos XIII-XIX: perspectiva general y factores agravantes, in: Sanchis-Ibor, C., Palau-Salvador, G., Mangue Alférez, I., Martínez-Sanmartín, L.P. (Eds.), Irrigation, Society and Landscape. Tribute to Thomas F. Glick. Universitat Politècnica de València, Valencia, Spain, pp. 559-577. doi:dx.doi.org/10.4995/ ISL2014.2014.179

Peris-Albentosa, T., 2014b. La articulación de entidades hidráulicas e instituciones políticas en la Huerta de Valencia (siglos XIII-XIX). El limitado intervencionismo de la corona., in: Sanchis-Ibor, C., Palau-Salvador, G., Mangue Alférez, I., Martínez-Sanmartín, L.P. (Eds.), Irrigation, Society and Landscape. Tribute to Thomas F. Glick. Universitat Politècnica de València, Valencia, Spain, pp. 578597. doi:dx.doi.org/10.4995/ISL2014.2014.71

Peris-Albentosa, T., 1997. La conflictividad hidráulica en el país valenciano entre los siglos XIII y XVIII. Areas: Revista internacional de ciencias sociales 17, 43-60.

Perry, C., 2008. Pricing Savings, Valuing Losses and Measuring Costs: Do We Really Know How to Talk about Improved Water Management?, in: Albiac, J., Dinar, A. (Eds.), The Management of Water Quality and Irrigation Technologies. Earthscan, London, pp. 179-196.

Perry, C., 2007. Efficient irrigation; inefficient communication; flawed recommendations. Irrigation and Drainage 56, 367-378. doi:10.1002/ird.323

Perry, C., Steduto, P., Allen, R.G., Burt, C.M., 2009. Increasing productivity in irrigated agriculture: Agronomic constraints and hydrological realities. Agricultural Water Management 96, 1517-1524. doi:10.1016/j.agwat.2009.05.005 
Pimentel Equihua, J.L., 2006. Organización social autogestiva y cogestión en el Río Júcar: el caso de la Acequia Real del Júcar, Comunidad de Valencia (PhD Dissertation). Universidad de Córdoba, Córdoba, Spain.

Playán, E., Mateos, L., 2006. Modernization and optimization of irrigation systems to increase water productivity. Agricultural Water Management 80, 100-116. doi:10.1016/j.agwat.2005.07.007

Pohl, C., 2005. Transdisciplinary collaboration in environmental research. Futures 37, 1159-1178. doi:10.1016/j.futures.2005.02.009

Poteete, A.R., Janssen, M.A., Ostrom, E., 2011. Working together. Collective action, the commons, and multiple methods in practice. Princeton University Press, Princeton, US.

Pulido-Velazquez, M., Jenkins, M.W., Lund, J.R., 2004. Economic values for conjunctive use and water banking in southern California. Water Resour. Res. 40, W03401. doi:10.1029/2003WR002626

Raadgever, G.T., Dieperink, C., Driessen, P.P.J., Smit, A.A.H., van Rijswick, H.F.M.W., 2011. Uncertainty management strategies: Lessons from the regional implementation of the Water Framework Directive in the Netherlands. Environmental Science \& Policy 14, 64-75. doi:10.1016/j.envsci.2010.11.001 Ramón-Morte, A., 1995. Tecnificación del regadío valenciano. Análisis territorial de la definición del sistema de riego localizado, Serie Estudios. Ministerio de Agricultura Pesca y Alimentación, Madrid, Spain.

Rasmussen, M.B., Orlove, B. (Eds.), 2014. Introduction. American Anthropologist, Virtual Issue: Anthropologists Exploring Water in Social and Cultural Life.

Rica, M., López-Gunn, E., Llamas, R., 2012. Analysis of the emergence and evolution of collective action: An empirical case of spanish groundwater user associations. Irrigation and Drainage 61, 115-125. doi:10.1002/ird.1663

Rivera, A., Sahuquillo, A., Andreu, J., Mukherji, A., 2005. Opportunities of conjunctive use of groundwater and surface water, in: Sahuquillo, A., Capilla, J., MartinezCortina, L., SanchezVila, X. (Eds.), Groundwater Intensive Use. Taylor and Francis, London, pp. 371-383.

Rivera, J.A., 1998. Acequia culture: water, land, and community in the Southwest. University of New Mexico Press, Albuquerque, US. 
Ross, A., Martinez-Santos, P., 2009. The challenge of groundwater governance: case studies from Spain and Australia. Reg Environ Change 10, 299-310. doi:10.1007/ s10113-009-0086-8

Roth, D., Boelens, R., Zwarteveen, M., 2005. Liquid relations: Contested water rights and legal complexity. Rutgers University Press, New Brunswick, US.

Sahuquillo, A., 2006. Strategies for the conjunctive use of surface and groundwater, in: Andreu, J., Rossi, G., Vagliasindi, F., Vela (Eds.), Drought Management and Planning for Water Resources. Taylor and Francis, Boca Raton, US, pp. 49-71.

Sahuquillo, A., 1989. Economic aspects of the conjunctive use of ground and surface water. Developments in Water Science, Groundwater Economics Selected Papers from A United Nations Symposium Held in Barcelona 39, 347-359.

Sahuquillo, A., Andreu, J., Pulido, M., Paredes, J., Sanchez, A., Pinilla, V., Capilla, J., 2005. Water resources management of an overexploited aquifer - The AdraCampo de Dallas system, Almeria, Spain, in: Sahuquillo, A., Capilla, J., Martinez Cortina, L., Sanchez Vila, X. (Eds.), Groundwater Intensive Use. Taylor and Francis, London, pp. 361-370.

Salazar, M.G., 2014. Policies, complexity and the need for cooperation in epistemic inquiry for the stable use of natural resources. Environmental Science \& Policy 37, 91-100. doi:10.1016/j.envsci.2013.09.002

Sales Martínez, V., 1988. La cuestión del extremal en el regadío de la real acequia de Moncada. Cuadernos de Geografía 44, 221-234.

Sales-Martínez, V., Ortega-Reig, M., Palau-Salvador, G., 2014. Expansión del regadío tradicional y control local en la Real Acequia de Moncada, in: Sanchis-Ibor, C., Palau-Salvador, G., Mangue Alférez, I., Martínez-Sanmartín, L.P. (Eds.), Irrigation, Society and Landscape. Tribute to Thomas F. Glick. Universitat Politècnica de València, Valencia, Spain, pp. 475-492. doi:dx.doi.org/10.4995/ ISL2014.2014.75

Sanchis-Ibor, C., García-Mollá, M., Avellá-Reus, L., 2016. Las políticas de implantación del riego localizado. Efectos en las entidades de riego de la Comunidad Valenciana. Boletín de la AGE (forthcoming). 
Saravanan, V.S., 2015. Agents of institutional change: The contribution of new institutionalism in understanding water governance in India. Environmental Science \& Policy, Special issue: Crafting or designing? Science and politics for purposeful institutional change in Social-Ecological Systems 53, Part B, 225235. doi:10.1016/j.envsci.2015.01.012

Schlager, E., 2007. Community management of groundwater, in: The Agricultural Groundwater Revolution. Opportunities and Threats to Development. CABI, Wallingford, UK, pp. 131-152.

Sengupta, N., 1991. Managing common property: irrigation in India and the Philippines. Sage Publications, New Delhi.

Sese-Minguez, S., 2012. Perspectives of different stake holders to implement drip irrigation systems and its consequences for land and water use. A case study in Cànyoles river basin, Valencia (Spain) (MSc Thesis). Wageningen University, Wageningen, Netherlands.

Shah, T., 2014. Innovation in agricultural groundwater management: examples from India, in: Garrido, A., Shechter, M. (Eds.), Water for the Americas: Challenges and Opportunities. Routledge, pp. 253-270.

Shah, T., 2012. Community response to aquifer development: Distinct patterns in India's alluvial and hard rock aquifer areas. Irrigation and Drainage 61, 14-25. doi:10.1002/ird.1656

Shah, T., 2009. Taming the anarchy: Groundwater governance in South Asia. Resources for the future press, Washington, DC.

Shah, T., 2007. The groundwater economy of South Asia: an asessment of size, significance and socio-ecological impacts, in: The Agricultural Groundwater Revolution. Opportunities and Threats to Development. CABI, Wallingford, UK, pp. 7-36.

Shah, T., 1993. Groundwater markets and irrigation development: political economy and practical policy. Oxford University Press, Mumbai, India.

Shah, T., Bhatt, S., Shah, R.K., Talati, J., 2008. Groundwater governance through electricity supply management: Assessing an innovative intervention in Gujarat, western India. Agricultural Water Management 95, 1233-1242. doi:10.1016/j. agwat.2008.04.006 
Shah, T., Darghouth, S., Dinar, A., 2006. Conjunctive use of groundwater and surface water, in: Agricultural and Rural Development Notes. World Bank, Washington, DC.

Shivakoti, G., Ostrom, E., 2002. Improving irrigation governance and management in Nepal. Institute for Comparative Studies Press, Oakland, US.

Shrestha, R.B., Gopalakrishnan, C., 1993. Adoption and diffusion of drip irrigation technology: An econometric analysis. Economic Development and Cultural Change 41, 407-418.

Singh, K.K., 1984. Farmers' associations in the Pochampad irrigation project: A case study; in Participatory Experiences in Irrigation Water Management, in: Proceedings of the Expert Consultation on Irrigation Water Management. Food and Agriculture Organization of the United Nations, Yogyakarta and Bali, Indonesia, pp. 95-116.

Siy, R.Y., 1989. A tradition of collective action: Farmers and irrigation in the Philippines, in: Korten, R.F., Siy, R.Y. (Eds.), Transforming a Bureaucracy: The Experience of the Philippine National Irrigation Administration. Atteno De Manila University Press, Philippines.

Siy, R.Y., Jr., 1982. Community resource management: Lessons from the Zanjera. University of the Philippines Press, Quezon City.

Soto-García, M., Del-Amor-Saavedra, P., Martin-Gorriz, B., Martínez-Alvarez, V., 2013a. The role of information and communication technologies in the modernisation of water user associations' management. Computers and Electronics in Agriculture 98, 121-130. doi:10.1016/j.compag.2013.08.005

Soto-García, M., Martínez-Alvarez, V., García-Bastida, P.A., Alcon, F., Martin-Gorriz, B., 2013b. Effect of water scarcity and modernisation on the performance of irrigation districts in south-eastern Spain. Agricultural Water Management 124, 11-19. doi:10.1016/j.agwat.2013.03.019

Soto-García, M., Martínez-Alvarez, V., García-Bastida, P.A., Alcon, F., Martin-Gorriz, B., 2013c. Effect of water scarcity and modernisation on the performance of irrigation districts in south-eastern Spain. Agricultural Water Management 124, 11-19. doi:10.1016/j.agwat.2013.03.019 
Stern, P.C., Dietz, T., Dolsak, N., Ostrom, E., Stonich, S., 2002. Knowledge and questions after 15 years of research, in: The Drama of the Commons. National Academy Press, Washington, DC.

Suhardiman, D., Giordano, M., Rap, E., Wegerich, K., 2014. Bureaucratic reform in irrigation: a review of four case studies. Water Alternatives 7, 442-463.

Sunding, D., Zilberman, D., 2000. The agricultural innovation process: Research and technology adoption in a changing agricultural sector, in: Gardner, B.L., Rausser, G.C. (Eds.), Handbook of Agricultural Economics. North-Holland/ Elsevier Science, Amsterdam, pp. 207-262.

Swyngedouw, E., 2013. UN Water Report 2012: Depoliticizing water. Development and Change 44, 823-835. doi:10.1111/dech.12033

Swyngedouw, E., 2009. The political economy and political ecology of the hydrosocial cycle. Journal of Contemporary Water Research \& Education 142, 56-60. doi:10.1111/j.1936-704X.2009.00054.x

Swyngedouw, E., 2007. Technonatural revolutions: the scalar politics of Franco's hydrosocial dream for Spain, 1939-1975. Transactions of the Institute of British Geographers 32, 9-28. doi:10.1111/j.1475-5661.2007.00233.x

Swyngedouw, E., 1999. Modernity and hybridity: Nature, regeneracionismo, and the production of the Spanish waterscape, 1890-1930. Annals of the Association of American Geographers 89, 443-465. doi:10.1111/0004-5608.00157

Tang, S.Y., 1992. Institutions and collective action: Self-governance in irrigation. ICS Press, San Francisco, US.

Thiel, A., Adamseged, M.E., Baake, C., 2015. Evaluating an instrument for institutional crafting: How Ostrom's social-ecological systems framework is applied. Environmental Science \& Policy, Special issue: Crafting or designing? Science and politics for purposeful institutional change in Social-Ecological Systems 53, Part B, 152-164. doi:10.1016/j.envsci.2015.04.020

Trawick, P., 2010. Encounters with the moral economy of water: General principles for successfully managing the commons, in: Brown, P., Schmidt, J.J. (Eds.), Water Ethics: Foundational Readings for Students and Professionals. Island Press, Washington, DC., pp. 155-166. 
Trawick, P., 2008. Scarcity, equity, and transparency: General principles for successfully governing the water commons, in: Mountains: Sources of Water, Sources of Knowledge. Springer, Dodrecht, Netherlands, pp. 43-61.

Trawick, P., 2005. Going with the flow: The state of contemporary studies of water management in Latin America. Latin American Research Review 40, 443-456. doi:10.1353/lar.2005.0068

Trawick, P., 2003a. The struggle for water in Peru: Comedy and tragedy in the Andean commons. Stanford University Press, Palo Alto, US.

Trawick, P., 2003b. Against the privatization of water: An indigenous model for improving existing laws and successfully governing the commons. World Development 31, 977-996. doi:10.1016/S0305-750X(03)00049-4

Trawick, P., 2002. Trickle down theory, Andean style. Natural History 111, 60-65.

Trawick, P., 2001a. The moral economy of water: Equity and antiquity in the Andean commons. American Anthropologist 103, 361-379. doi:10.1525/ aa.2001.103.2.361

Trawick, P., 2001b. Successfully governing the commons: Principles of social organization in an Andean irrigation system. Human Ecology: An Interdisciplinary Journal 29, 1-25. doi:10.1023/A:1007199304395

Trawick, P., 1994. The struggle for water in the Andes: A study of technological change and social decline in the Cotahuasi Valley of Peru ( $\mathrm{PhD}$ Dissertation). Yale University, New Haven, US.

Trawick, P., Morris, J., Posthumus, H., Cook, M., Sinclair, F., 2006. Sustainable development as a "collective choice" problem: theoretical and practical implications of success exemplified in locally managed irrigation (summary report for DEFRA Project EPES 0506/14). Cranfield University, Silsoe, UK.

Treacy, J.M., 1994a. Las chacras de Coporaque: andenería y riego en el valle del Colca. Instituto de Estudios Peruanos, Lima.

Treacy, J.M., 1994b. Teaching water: Hydraulic management and terracing in Corporaque, the Colca Valley, Peru., in: Irrigation at High Altitudes: The Social Organization of Water Control Systems in the Andes., Society for Latin American Anthropology Publication Series. American Anthropological Association, Washington, DC., pp. 99-114. 
Uphoff, N., 1986. Getting the process right: Improving water management with farmer organisation and participation (Working Paper). Cornell University, Ithaca, US.

Uphoff, N., Meinzen-Dick, R., St. Julien, N., 1985. Improving policies and programs for farmer organization and participation in irrigation water management (Water Management Synthesis II). Cornell University, Ithaca, US.

Uphoff, N., Wijayaratna, C.M., 2000. Demonstrated benefits from social capital: The productivity of farmer organizations in Gal Oya, Sri Lanka. World Development 28, 1875-1890. doi:10.1016/S0305-750X(00)00063-2

van der Kooij, S., Zwarteveen, M., Boesveld, H., Kuper, M., 2013a. The efficiency of drip irrigation unpacked. Agricultural Water Management 123, 103-110. doi:10.1016/j.agwat.2013.03.014

van der Kooij, S., Zwarteveen, M., Boesveld, H., Kuper, M., 2013b. Erratum to "The efficiency of drip irrigation unpacked" [Agricultural Water Management 123 (2013) 103-110]. Agricultural Water Management 127, 124-126. doi:10.1016/j. agwat.2013.06.012

van der Kooij, S., Zwarteveen, M., Kuper, M., 2015. The material of the social: the mutual shaping of institutions by irrigation technology and society in Seguia Khrichfa, Morocco. International Journal of the Commons 9, 129-150.

Venot, J.-P., Jella, K., Bharati, L., George, B., Biggs, T., Rao, P.G., Gumma, M.K., Acharya, S., 2010. Farmers' adaptation and regional land-use changes in irrigation systems under fluctuating water supply, South India. Journal of Irrigation and Drainage Engineering 136, 595-609. doi:10.1061/(ASCE)IR.1943-4774.0000225

Venot, J.-P., Zwarteveen, M., Kuper, M., Boesveld, H., Bossenbroek, L., van der Kooij, S., Wanvoeke, J., Benouniche, M., Errahj, M., De Fraiture, C., Verma, S., 2014. Beyond the promises of technology: A review of the discourses and actors who make drip irrigation. Irrigation and Drainage 63, 186-194. doi:10.1002/ird.1839 Vidal, A., Comeau, A., Plusquellec, H., Gadelle, F., 2001. Case studies on water conservation in the Mediterranean (Knowledge Synthesis Report No.4). IPTRID/ FAO, Rome, Italy. 
Villamayor-Tomas, S., 2014. Cooperation in common property regimes under extreme drought conditions: Empirical evidence from the use of pooled transferable quotas in Spanish irrigation systems. Ecological Economics 107, 482-493. doi:10.1016/j.ecolecon.2014.09.005

Villanueva, H., Sherbondy, J., 1979. Cuzco: Aguas y poder. Centro de Estudios Rurales Andinos San Bartolomé de Las Casas, Cuzco, Perú.

Wade, R., 1987. Village Republics. Cambridge University Press, Mumbai, India.

Wade, R., 1986. Common property resource management in South Indian Villages., in: Proceedings of the Conference on Common Property Resource Management. National Academiey Press, Washington, DC., pp. 231-258.

Ward, F.A., Pulido-Velazquez, M., 2008. Water conservation in irrigation can increase water use. Proceedings of the National Academy of Sciences 105, 18215-18220. doi:10.1073/pnas.0805554105

Wittfogel, K.A., 1957. Oriental Despotism. Yale University Press, New Haven, US.

World Bank, 2004. Water resources sector strategy : strategic directions for World Bank engagement (No. 28114). World Bank, Washington D.C., U.S.

WWAP, (World Water Assessment Programme), 2015. The United Nations World Water Development Report 2015: Water for a Sustainable World. Paris.

WWF/Adena, 2015. Modernización de regadíos. Un mal negocio para la naturaleza y la sociedad. Madrid, Spain. 

